\title{
Water-Chemistry Evolution and Modeling of Radionuclide Sorption and Cation Exchange during Inundation of Frenchman Flat Playa
}

\author{
Prepared by \\ Ronald L. Hershey, Mary E. Cablk, Karen LeFebre, \\ Lynn F. Fenstermaker, and David L. Decker
}

submitted to

Nevada Field Office

National Nuclear Security Administration

U.S. Department of Energy

Las Vegas, Nevada

August 2013

Publication No. 45252 
Reference herein to any specific commercial product, process, or service by trade name, trademark, manufacturer, or otherwise, does not necessarily constitute or imply its endorsement, recommendation, or favoring by the United States Government or any agency thereof or its contractors or subcontractors.

Available for sale to the public from:

U.S. Department of Commerce

National Technical Information Service

5301 Shawnee Road

Alexandria, VA 22312

Phone: 800.553.6847

Fax: 703.605.6900

Email: orders@ntis.gov

Online ordering: http://www.ntis.gov/help/ordermethods.aspx

Available electronically at http://www.osti.gov/bridge

Available for a processing fee to the U.S. Department of Energy and its contractors, in paper, from:

U.S. Department of Energy

Office of Scientific and Technical Information

P.O. Box 62

Oak Ridge, TN 37831-0062

Phone: 865.576.8401

Fax: 865.576.5728

Email: mailto:reports@adonis.osti.gov 


\title{
Water-Chemistry Evolution and Modeling of Radionuclide Sorption and Cation Exchange during Inundation of Frenchman Flat Playa
}

\author{
Prepared by \\ Ronald L. Hershey, Mary E. Cablk, Karen LeFebre, \\ Lynn F. Fenstermaker, and David L. Decker \\ Desert Research Institute \\ Nevada System of Higher Education \\ Publication No. 45252 \\ submitted to \\ Nevada Field Office \\ National Nuclear Security Administration \\ U.S. Department of Energy \\ Las Vegas, Nevada
}

August 2013

The work upon which this report is based was supported by the U.S. Department of Energy under Contract numbers DE-AC52-06NA26383 and DE-NA0000939. Approved for public release; further dissemination unlimited. 
THIS PAGE INTENTIONALLY LEFT BLANK 


\section{EXECUTIVE SUMMARY}

Atmospheric tests and other experiments with nuclear materials were conducted on the Frenchman Flat playa at the Nevada National Security Site, Nye County, Nevada; residual radionuclides are known to exist in Frenchman Flat playa soils. Although the playa is typically dry, extended periods of winter precipitation or large single-event rainstorms can inundate the playa. When Frenchman Flat playa is inundated, residual radionuclides on the typically dry playa surface may become submerged, allowing water-soil interactions that could provide a mechanism for transport of radionuclides away from known areas of contamination. The potential for radionuclide transport by occasional inundation of the Frenchman Flat playa was examined using geographic information systems and satellite imagery to delineate the timing and areal extent of inundation; collecting water samples during inundation and analyzing them for chemical and isotopic content; characterizing suspended/precipitated materials and archived soil samples; modeling water-soil geochemical reactions; and modeling the mobility of select radionuclides under aqueous conditions. The physical transport of radionuclides by water was not evaluated in this study.

Frenchman Flat playa was inundated with precipitation during two consecutive winters in 2009-2010 and 2010-2011. Inundation allowed for collection of multiple water samples through time as the areal extent of inundation changed and ultimately receded. During these two winters, precipitation records from a weather station in Frenchman Flat (Well 5b) provided information that was used in combination with geographic information systems, Landsat imagery, and image processing techniques to identify and quantify the areal extent of inundation. After inundation, water on the playa disappeared quickly, for example, between January 25, 2011 and February 10, 2011, a period of 16 days, 92 percent of the areal extent of inundation receded $\left(2,062,800 \mathrm{~m}^{2}\right)$.

Water sampling provided valuable information about chemical processes occurring during inundation as the water disappeared. Important observations from water-chemistry analyses included: 1 ) total dissolved solids (TDS) and chloride ion $\left(\mathrm{Cl}^{-}\right)$concentrations were very low (TDS: < $200 \mathrm{mg} / \mathrm{L}$ and $\mathrm{Cl}^{-}:<3.0 \mathrm{mg} / \mathrm{L}$, respectively) for all water samples regardless of time or areal extent; 2 ) all dissolved constituents were at concentrations well below what might be expected for evaporating shallow surface waters on a playa, even when 98 to 99 percent of the water had disappeared; 3) the amount of evaporation for the last water samples collected at the end of inundation, estimated with the stable isotopic ratios $\delta^{2} \mathrm{H}$ or $\delta^{18} \mathrm{O}$, was approximately 60 percent; and 4) water samples analyzed by gamma spectroscopy did not show any man-made radioactivity; however, the short scanning time (24 hours) and relative chemical diluteness of the water samples (TDS ranged between 39 and $190 \mathrm{mg} / \mathrm{L}$ ) may have contributed to none being detected. Additionally, any low-energy beta emitting radionuclides would not have been detected by gamma spectroscopy.

From these observations, it was apparent that a significant portion of water on the playa did not evaporate, but rather infiltrated into the subsurface (approximately 40 percent). Consistent with this water chemistry-based conclusion is particle-size analysis of two archived Frenchman Flat playa soils samples, which showed low clay content in the near surface soil that also suggested infiltration. Infiltration of water from the playa during inundation into the subsurface does not necessarily imply that groundwater recharge is 
occurring, but it does provide a mechanism for moving residual radionuclides downward into the subsurface of Frenchman Flat playa.

Water-mineral geochemical reactions were modeled so that changes in the water chemistry could be identified and the extent of reactions quantified. Geochemical modeling showed that evaporation; equilibrium with atmospheric carbon dioxide and calcite; dissolution of sodium chloride, gypsum, and composite volcanic glass; and precipitation of composite clay and quartz represented changes in water as it disappeared from the playa. This modeling provided an understanding of the water-soil geochemical environment, which was then used to evaluate the potential mobility of residual radionuclides into the playa soils by water.

Because there is no information on the chemical forms of anthropogenic radionuclides in Frenchman Flat playa soil, it was assumed that soil radionuclides go into solution when the playa is inundated. In mobility modeling, a select group of radionuclides were allowed to sorb onto, or exchange with, playa soil minerals to evaluate the likelihood that the radionuclides would be removed from water during playa inundation. Radionuclide mobility modeling suggested that there would be minimal sorption or exchange of several important radionuclides (uranium, cesium, and technetium) with playa minerals such that they may be mobile in water when the playa is inundated and could infiltrate into the subsurface. Mobility modeling also showed that plutonium may be much less mobile because of sorption onto calcite, but the amount of reactive surface area of playa soil calcite is highly uncertain. Plutonium is also known to sorb onto colloidal particles suspended in water, suspended colloidal particles will move with the water, providing a mechanism to redistribute plutonium when Frenchman Flat playa is inundated.

Water chemistry, stable isotopes, and geochemical modeling showed that residual radionuclides in Frenchman Flat playa soils could be mobilized in water when the playa is inundated with precipitation. Also, there is potential for these radionuclides to infiltrate into the subsurface with water. As a result of the information obtained both during this study and the conclusions drawn from it, additional data collection, investigation, and modeling are recommended. Specifically: sampling the playa soil to search for evidence of surface-water infiltration and the presence of radionuclides; developing a preliminary unsaturated flow and transport model to guide soil sampling; characterizing the chemical forms of radionuclides on the playa surface and any radionuclides that might have migrated into the subsurface; and, refining the unsaturated flow and transport model with data obtained from sampling and analysis of soil samples to guide any future sampling, development of remediation strategies, and defining risk-based boundaries for Frenchman Flat playa. 


\section{CONTENTS}

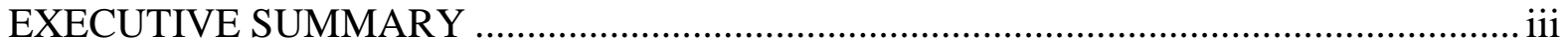

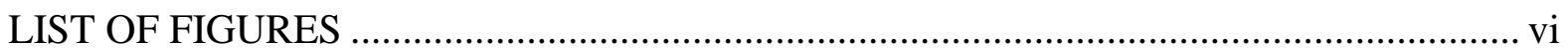

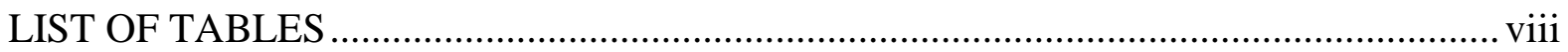

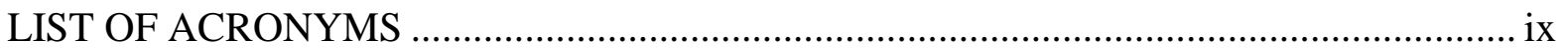

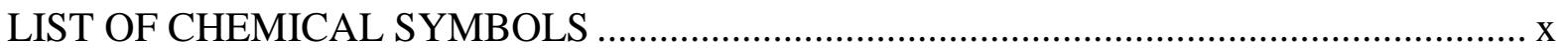

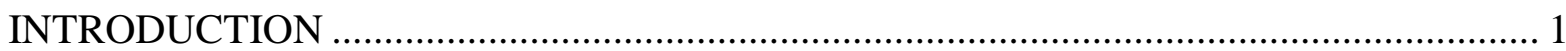

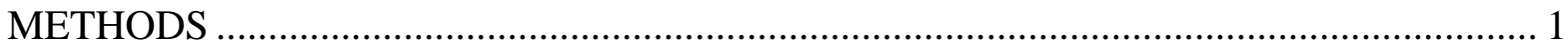

Duration and Extent of Playa Inundation .................................................................... 1

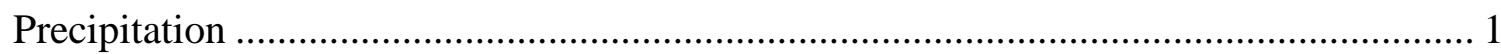

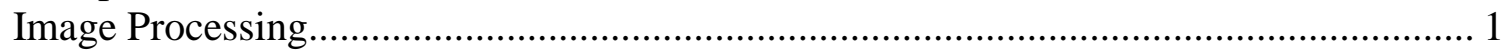

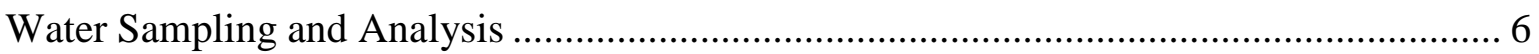

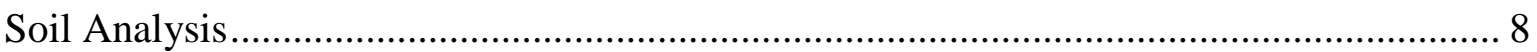

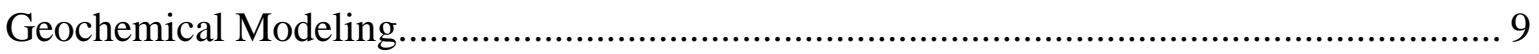

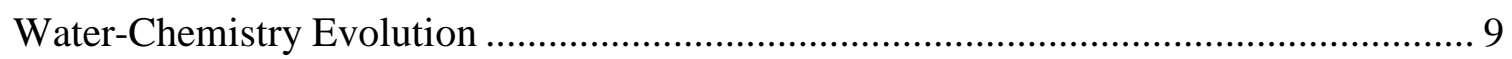

Radionuclide Sorption and Cation Exchange................................................................. 10

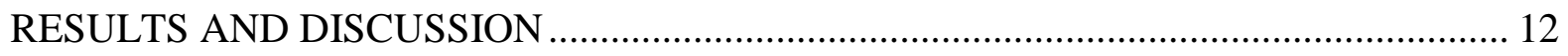

Duration and Extent of Playa Inundation ................................................................... 12

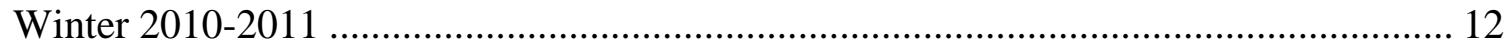

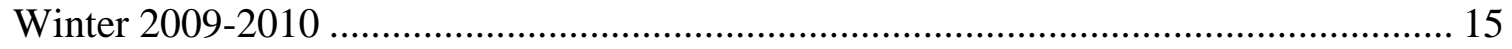

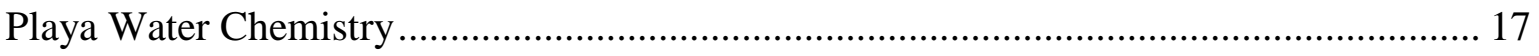

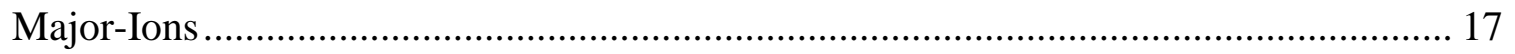

Hydrogen and Oxygen Isotopes ................................................................................ 20

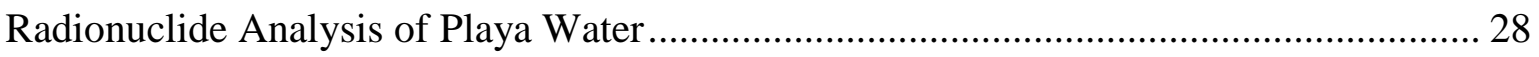

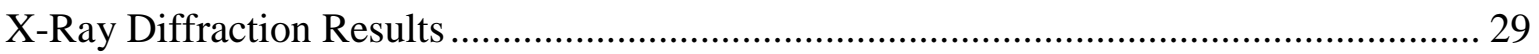

Water-Soil Geochemical Reaction Modeling................................................................. 31

Radionuclide Aqueous Mobility Modeling ................................................................... 37

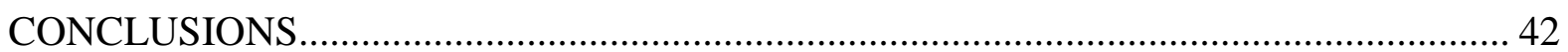

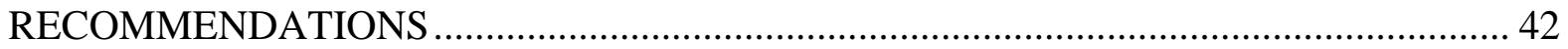

REFERENCES ............................................................................................................ 43

APPENDIX A: Extent of inundation on Frenchman Flat playa during the winters of 2009-2010 and 2010-2011..................................................................... A-1

APPENDIX B: Saturation indices of important minerals, calculated by PHREEQC, for playa water samples................................................................................ B-1 


\section{LIST OF FIGURES}

1. Location of Frenchman Flat playa, Nevada National Security Site, southern Nevada...... 2

2. 1994 fly over survey of Frenchman Flat playa (DOE, 2010b)...................................... 3

3. Comparison of Landsat 5 scene (bands 7, 5, 4) acquired March 10, 1998 (left) and the result of the TC transformation (right).

4. Processing steps to extract inundation for each date and calculate persistence of inundation through time.

5. An example of a small residual pool of water on Frenchman Flat playa from winter 2009-2010. Water samples were collected at this location (\#3) on March 9, 2010.......... 7

6. Persistence of inundation on Frenchman Flat playa for the winter of 2010-2011. Persistence was calculated by summing each pixel on every Landsat scene (each scene date) that was inundated

7. Extent of inundation and water sampling locations on Frenchman Flat playa for the Landsat scene on January 9, 2011.

8. Extent of inundation and water sampling locations on Frenchman Flat playa for the Landsat scene on January 25, 2011.

9. Extent of inundation and water sampling locations on Frenchman Flat playa for the Landsat scene on February 10, 2011.

10. Persistence of inundation on Frenchman Flat playa for the winter of 2009-2010. Persistence was calculated by summing each pixel on every Landsat scene (each scene date) that was inundated.

11. Extent of inundation and water sampling locations on Frenchman Flat playa for the Landsat scene on March 11, 2010.

12. Major-ion diagram of water samples during inundation of Frenchman Flat playa from March 2010, January 2011, and February 2011.

13. $\mathrm{Cl}^{-}$vs. TDS for water samples during inundation of Frenchman Flat playa. 20

14. $\delta^{2} \mathrm{H}$ and $\delta^{18} \mathrm{O}$ of water samples collected in the winters of 2009-2010 and 20102011from Frenchman Flat playa during inundation.... 21

15. Inundation of Frenchman Flat playa on January 5, 2011.

16. Homogenous isotopic signature of water samples from Frenchman Flat playa shortly after the maximum extent of inundation in the winter of 2010-2011. 23

17. Sampling location \#1, January 5, 2011.................................................................. 24

18. Sampling location \#1 on February 16, 2011.............................................................. 24

19. No change in isotopic signature (no evaporation) from sample location \#1 as water on Frenchman Flat playa receded. 25

20. Sample location \#4 on January 26, 2011. 25

21. Change in isotopic signature showing evaporation at sample location \#4 from, January 5, 2011 to January 26, 2011. 26

22. Evaporation line for sample location \#4 from January 5, 2011 to January 26, 2011....... 26 
23. The isotopic signatures of water samples from the winter of 2010-2011 plot along the evaporation line for sample location \#4 from January 5, 2011 to January 26, 2011.

24. Comparison of PHREEQC modeling simulations to actual water chemistry changes at sample location \#4 from January 5 to January 26, 2011. 33

25. Comparison of PHREEQC modeling simulation to actual water chemistry changes at sample location \#4 from January 5 to January 26, 2011. 34

26. Comparison of PHREEQC model simulation to actual water chemistry changes at sample location \#4 from January 5 to January 26, 2011................................................ 35

27. Comparison of PHREEQC model simulation to actual water chemistry changes at sample location \#1 from January 26 to February 16, 2011.............................................. 36

28. Modeled aqueous U(VI) sorption onto HFO in Frenchman Flat soils............................. 39

29. Modeled aqueous $\mathrm{Pu}(\mathrm{V})$ sorption onto HFO in Frenchman Flat soils............................. 40

30. Modeled aqueous $\mathrm{Pu}(\mathrm{V})$ sorption onto calcite in Frenchman Flat soils. .......................... 40

31. Modeled aqueous Cs(I) exchange onto clays in Frenchman Flat soils............................ 41 


\section{LIST OF TABLES}

1. Frenchman Flat playa inundation water sample dates, numbers, and locations. .............. 8

2. Mineral phases, chemical formulas, and dissolved ions used in geochemical modeling.

3. Aqueous and surface reactions used in uranium surface complexation modeling (Wazne et al., 2003). 11

4. Aqueous and surface reactions used in plutonium surface complexation modeling ....... 11

5. Monthly total precipitation at the W5b weather station in Frenchman Flat for the winter of 2010-2011

6. Total surface area of inundation on Frenchman Flat playa by Landsat scene for the winter of 2010-2011.

7. Monthly total precipitation at the W5b weather station in Frenchman Flat for the winter of 2009-2010.

8. Total surface area of inundation on Frenchman Flat playa by Landsat scene for the winter of 2009-2010.

9. Major-ion chemistry of Frenchman Flat playa water samples.

10. $\delta^{2} \mathrm{H}$ and $\delta^{18} \mathrm{O}$ of water samples collected in the winters of 2009-2010 and 20102011from Frenchman Flat playa during inundation.

11. Estimates of evaporation from Frenchman Flat playa during inundation from January 5, 2011 to February 16, 2011.

12. Particle size analysis and textural classification for two archived Frenchman Flat playa soil samples.

13. Minerals identified by XRD in residual sediment, flocculated colloidal material, and precipitated materials from Frenchman Flat playa water samples.

14. Semi-quantitative XRD results for two archived Frenchman Flat soil samples from three different depths.

15. Qualitative XRD results for the clay-size fraction for two archived Frenchman Flat soil samples.

16. Relative error for water-soil mineral geochemical reaction modeling

17. Al concentrations from citrate-diothionite extraction; Fe concentrations from hydroxylamine extraction; BET surface area for archived Frenchman Flat soil samples. 


\section{LIST OF ACRONYMS}

BET Brunauer, Emmet, and Teller

cm centimeters

DOE U. S. Department of Energy

DRI Desert Research Institute

EPA U.S. Environmental Protection Agency

FY fiscal year

g gas

GA Georgia

GIS geographic information systems

GMWL global meteoric water line

ha hectares

ICP-AES inductively coupled plasma atomic emission spectroscopy

IR infrared

L liter

$\mathrm{mg} / \mathrm{g} \quad$ milligrams per gram

$\mathrm{mg} / \mathrm{L} \quad$ milligrams per liter

$\mathrm{m}^{2} \quad$ meters squared

$\mathrm{m}^{2} / \mathrm{g} \quad$ meters squared per gram

$\mathrm{mm} \quad$ millimeters

$\mu \mathrm{m} \quad$ micrometers

$\mu \mathrm{mol} / \mathrm{m}^{2} \quad$ micromoles per meters squared

mols moles

$\mathrm{NaCl}$ sodium chloride (a solid, also known as the mineral halite)

NEM non-electrostatic model

NNSA National Nuclear Security Administration

NNSS Nevada National Security Site

NSO Nevada Field Office

PCA principal component analysis

ppb parts per billion

SI saturation index

SLC scan line corrector

TC tasseled cap

TDS total dissolved solids

USGS United States Geological Survey

VSMOW Vienna standard mean ocean water standard for $\delta^{2} \mathrm{H}$ and $\delta^{18} \mathrm{O}$

W5b Well 5B

XRD X-ray diffraction 


\section{LIST OF CHEMICAL SYMBOLS}
Al aluminum
Am americium
$\mathrm{Br}^{-} \quad$ bromide ion
$\mathrm{Ca}^{2+} \quad$ calcium ion
$\mathrm{Cl}^{-} \quad$ chloride ion
$\mathrm{CO}_{2} \quad$ carbon dioxide
Cs cesium
Cs(I) cesium +1 valence state
$\delta^{2} \mathrm{H} \quad$ symbol for the hydrogen isotopic ratio $\left({ }^{2} \mathrm{H} /{ }^{1} \mathrm{H}\right)$ as compared to the standard VSMOW
$\delta^{18} \mathrm{O} \quad$ symbol for the oxygen isotopic ratio $\left({ }^{18} \mathrm{O} /{ }^{16} \mathrm{O}\right)$ as compared to the standard VSMOW
$\mathrm{F}^{-} \quad$ fluoride ion
$\mathrm{Fe} \quad$ iron
${ }^{2} \mathrm{H} \quad$ hydrogen-2
$\mathrm{HCO}_{3}{ }^{-} \quad$ bicarbonate ion
HFO hydrous ferric oxide
$\mathrm{K}^{+} \quad$ potassium ion
$\mathrm{Mg}^{2+} \quad$ magnesium ion
$\mathrm{N}^{2} \quad$ nitrogen gas
$\mathrm{Na}^{+} \quad$ sodium ion
$\mathrm{NaCl}$ sodium chloride (a solid, also known as the mineral halite)
${ }^{18} \mathrm{O}$ oxygen-18
$\mathrm{P}_{\mathrm{CO} 2}$ partial pressure of $\mathrm{CO}_{2}$
PCA principal component analysis
$\mathrm{Pu} \quad$ plutonium
$\mathrm{Pu}(\mathrm{IV}) \quad$ plutonium +4 valence state
$\mathrm{Pu}(\mathrm{V}) \quad$ plutonium +5 valence state
$\mathrm{Si} \quad$ silica
$\mathrm{SO}_{4}{ }^{2-} \quad$ sulfate ion
Tc technetium
Tc(VII) technetium +7 valence state
$\mathrm{TcO}^{4-} \quad$ pertechnetate anion
U uranium
$\mathrm{U}(\mathrm{VI}) \quad$ uranium +6 valence state 


\section{INTRODUCTION}

Atmospheric tests and other nuclear material experiments were conducted on the Frenchman Flat playa, Nevada National Security Site (NNSS), Nye County, Nevada (Figure 1). Radionuclides from these activities are present in Frenchman Flat playa soils (DOE 2010a; Figure 2 from DOE, 2010b; McArthur, 1991; McArthur and Mead, 1989). Although the playa is usually dry, extended periods of precipitation or large single-event rainstorms may inundate the playa. When the playa is inundated, radionuclides on the playa surface may be submerged for days, weeks, or even months creating an environment where water-soil-radionuclide interactions could release radionuclides into water. Dissolved radionuclides or radionuclides sorbed onto colloidal and suspended particles could be transported from areas of known contamination by water movement during inundation. This report examined the extent and duration of playa inundation during the winters of 2009-2010 and 2010-2011, the chemistry evolution of water during playa inundation as it receded during these winters, and the potential for sorption or cation exchange of select radionuclides hypothetically dissolved in the water onto playa soil mineral surfaces, which may limit (or enhance) radionuclide movement during playa inundation. The physical transport of radionuclides by water was not evaluated in this study.

To evaluate the potential for radionuclide movement when Frenchman Flat playa is inundated, the extent and duration of inundation in the winters of 2009-2010 and 2010-2011 was determined using geographic information systems (GIS) and image processing techniques; water was collected and analyzed for chemical constituents; suspended/precipitated materials were characterized; archived soil samples were characterized; water-soil geochemical reactions were modeled; and the sorption and cation exchange of select radionuclides were modeled. Future investigations will include collecting playa soils for characterization and radionuclide analysis as well as additional evaluation and modeling of radionuclide solubility and transport potential.

\section{METHODS}

\section{Duration and Extent of Playa Inundation}

\section{Precipitation}

Inundation of Frenchman Flat playa was observed during the winters of 2009-2010 and 2010-2011. The precipitation monitoring station closest to Frenchman Flat playa is the Well 5B (W5b) station (National Oceanic and Atmospheric Administration, Air Resources Laboratory http://www.sord.nv.doe.gov/home_climate_rain.htm). Monthly precipitation totals from the W5b station for the years 2009, 2010, and 2011 were examined.

\section{Image Processing}

Landsat satellite imagery was used to map and quantify the extent of inundation on the playa at discrete times. The Landsat Program originated in 1972 as a joint National Aeronautics and Space Administration and United States Geological Survey (USGS) program. The sensor on these satellites collects data measured by reflective light in the visible $(0.45 \mu-0.69 \mu)$, near infrared (IR) $(0.76 \mu-0.90 \mu)$, middle IR $(1.55 \mu-2.35 \mu)$, and thermal IR $(10.4 \mu-12.5 \mu)$ portions of the electromagnetic spectrum. At the time of this study, there were two functioning satellites, Landsat 5 and Landsat 7, both of which have a 


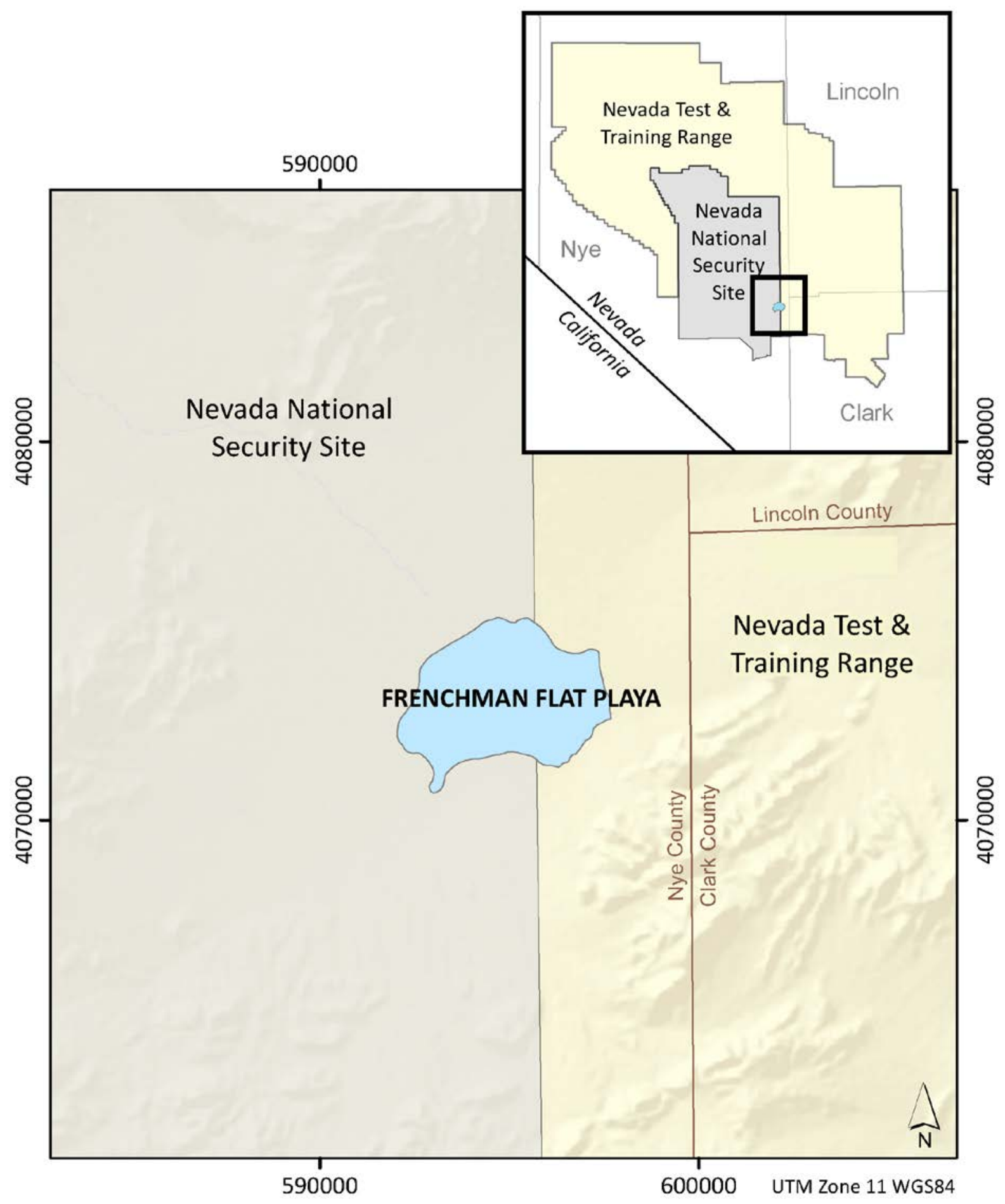

Figure 1. Location of Frenchman Flat playa, Nevada National Security Site, southern Nevada. 


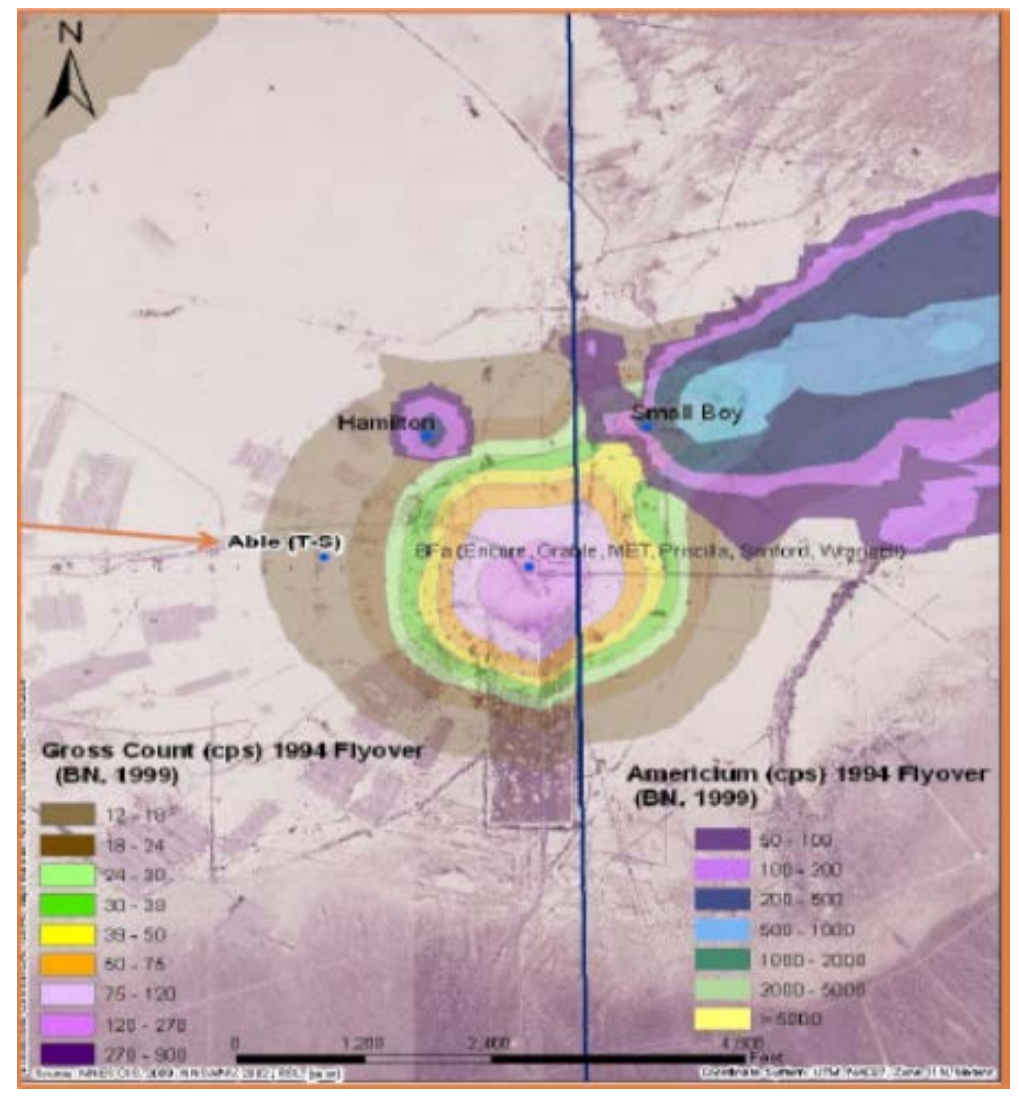

Figure 2. 1994 fly over survey of Frenchman Flat playa (DOE, 2010b).

nominal spatial resolution of $30 \mathrm{~m}$ with the exception of $120 \mathrm{~m}$ spatial resolution for the thermal band and $15 \mathrm{~m}$ spatial resolution for a panchromatic $(0.52 \mu-0.9 \mu)$ band on Landsat 7. Thermal data were not used for this analysis. Landsat 6 was lost at launch in 1993 and never reached orbit.

Both Landsat 5 and Landsat 7 are in polar, sun-synchronous orbits and circle the earth every 99 minutes with a 16-day repeat cycle. Each satellite crosses the same path and row at approximately the same time on over-flight days. Therefore, there are only discrete dates of imagery available for the study area, acquired every 16 days. Cloud cover and smoke, or other atmospheric interference, affects image quality and ground visibility, but do not preclude image acquisition. For this reason, it was necessary to review each scene before downloading and processing.

Images were downloaded via direct link to an active Landsat ground station. The data are stored as digital arrays, and each date of imagery for a given area is referred to as a "scene”. Image scenes are searchable according to the Worldwide Reference System (http://landsat.gsfc.nasa.gov/about/wrs.html), which categorizes each scene into a path (north-south) and row (east-west) designation. The path/row designation for scenes covering the study area is path 40, row 34. Each image file (scene) contains multiple bands of data corresponding to the specific wavelengths for which data are collected: Band 1 is visible blue, band 2 is visible green, band 3 is visible red, band 4 is near IR, band 5 is middle IR, band 6 is thermal IR, and band 7 is the middle IR band. In Landsat 7, band 8 is the 
panchromatic band, which encompasses the entire visible portion of the electromagnetic spectrum and has a nominal spatial resolution of $15 \mathrm{~m}$. Wavelengths between $0.7 \mu$ and $2.50 \mu$, spanning near IR and middle IR portions of the electromagnetic spectrum, are useful for identifying water. In this region of the electromagnetic spectrum, water bodies absorb almost all incident radiant flux, which is highly reflected off land features.

For this study, Landsat 5 imagery was selected over Landsat 7 imagery because Frenchman Flat playa lies in an area of the scene (path 40, row 34) that was affected by failure of the Scan Line Corrector (SLC) since May 2003. The SLC compensates for the forward motion of the satellite; without SLC operation, there are zigzag data gaps in the imagery. Where both Landsat 5 and Landsat 7 data were available prior to the SLC failure, images from both satellites were evaluated.

The images were reviewed first in the archive viewer to determine if the study area appeared cloud-free. The USGS Earth Resources Observation Systems Data Center maintains an archive of the data collected by the suite of Landsat satellites dating back to 1972. These data are searchable online and available to the public free of charge. Only those scenes that were cloud-free over the study area were requested. The downloaded images were processed to Level 1T. Level 1T processing indicates that the imagery was corrected for systematic (radiometric and geometric accuracy) error and terrain. This level of processing includes the use of ground control points and digital elevation model data for geometric accuracy. The files were uncompressed and imported into the image processing software Environment for Visualizing Images (ENVI) (http://www.exelisvis.com/language/enus/productsservices/envi.aspx). Bands 1 through 5 and band 7 were layer stacked by date and further reviewed for cloud cover. Layer stacking is a process that results in a scene of imagery that contains the selected spectral bands appropriate for the study (bands 1 through 3, which are visible light, band 4, which is near infrared, and bands 5 and 7, which are short wave infrared) collated for each date of acquisition. The final images or scenes are stored as multi-band digital arrays. Those scenes with cloud cover that fully obscured the playa were excluded from further analysis.

Each image scene was subset to the study area and transformed using the tasseled cap (TC) transformation following the approach of Miller et al. (2011). The TC is an orthogonal transformation and is a type of principal component analysis (PCA); however, unlike PCA, the TC uses a known set of algorithms where each band of Landsat data is transformed via a set of established equations (Crist and Cicone, 1984). The TC transformation for Landsat 5 imagery is calculated using the following coefficients:

Brightness $=$

0.3037(TM1)+0.2793(TM2)+0.4743(TM3)+0.5585(TM4)+0.5082(TM5)+0.1863(TM7)

Greenness =

-0.2848(TM1)-0.2435(TM2)-0.5436(TM3)+0.7243(TM4)+0.0840(TM5)-0.1800(TM7)

Wetness $=$

0.1509(TM1) + 0.1973(TM2)+0.3279(TM3)+0.3406(TM4)-0.7112(TM5)-0.4572(TM7)

where (TM\#) corresponds to each of the non-thermal spectral bands (1-5 and 7) in a Landsat image.

This process results in a transformation of the data against known axes, reduces data volume, and allows for an expected universal interpretation of the output components. The 
first three output component bands are labeled as general descriptors of the information contained within each: "brightness," "greenness," and "wetness” (Jin and Sader, 2005; Cohen and Spies, 1992). The resulting TC bands are used to optimize characterization of three basic elements: vegetation, soil, and water.

Running each imagery date through the TC transformation is more robust than calculating a simple ratio (e.g., band 7/band 4) in that there is no need for image-to-image correction and the feature space within output axes is standardized across geography. Playas represent unique features in terms of differentiating water from saturated soils because water depth can be in the millimeter range and because soil can be saturated without having measurable water on the surface. This is a very different scenario from differentiating a river from its riparian vegetation or a shoreline along a coast, for example. An advantage, therefore, of using the TC is that regardless of where in the world the scene was acquired, the location of pixels plotted in a two-dimensional graph representing water, dry soil, green vegetation, etc. remains consistent. For this reason, identifying water with the TC can be done more objectively than by attempting to guess thresholds based on simple band ratios. Because each scene evaluated was the same path and row and covered the same geographic location of the earth, threshold values of TC transformed images were applied consistently across each date of imagery. This approach was first explored by Miller et al. (2011) and remains in development. Figure 3 is an example from 1998 Landsat 5 imagery, with the output of the TC and the extent of inundation mapped based on the TC overlaid on each image. The infrared bands are shown, which have water absorbing properties, thus pixels appearing darker correspond to water.

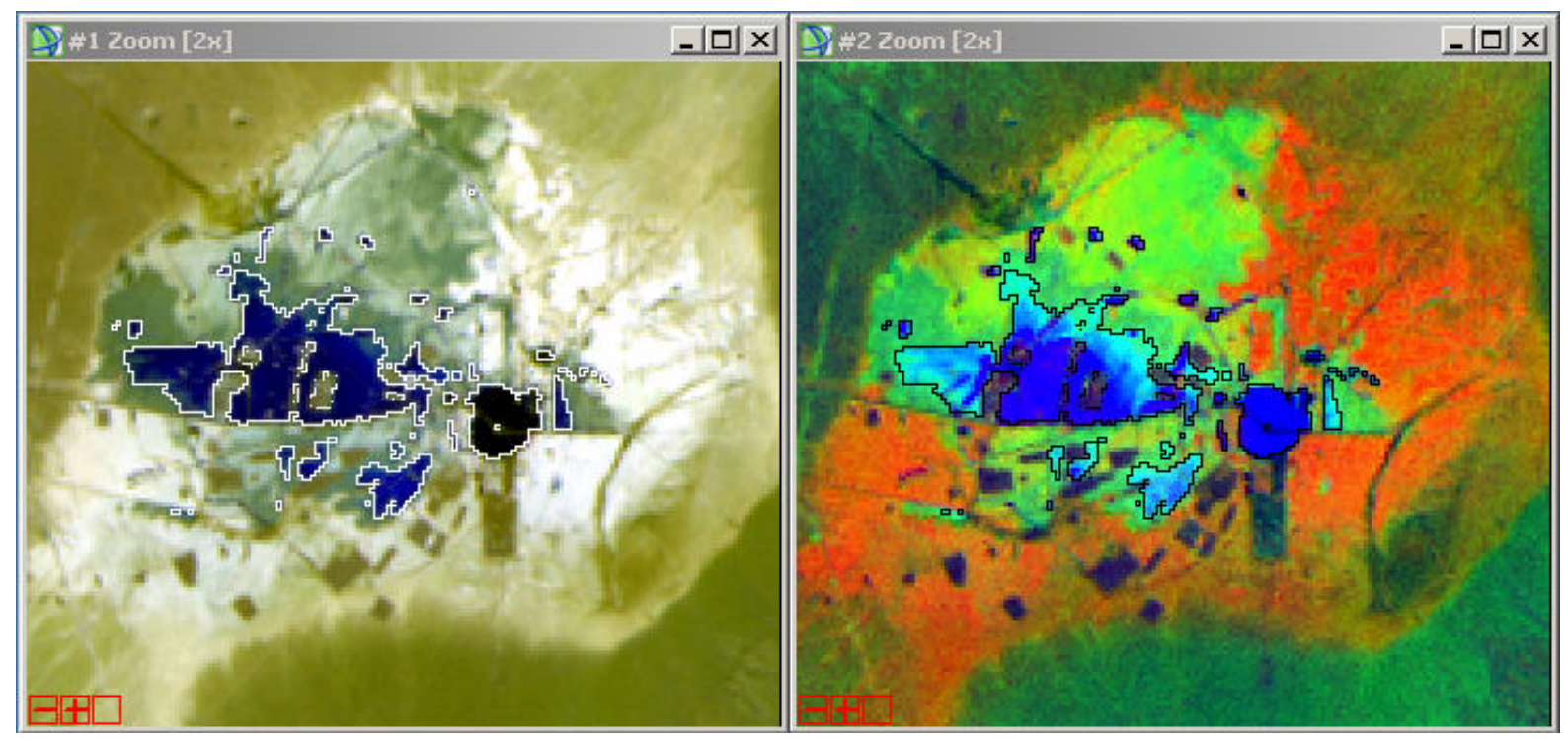

Figure 3. Comparison of Landsat 5 scene (bands 7, 5, 4) acquired March 10, 1998 (left) and the result of the TC transformation (right). The outline in white on the image (left) is the same outline in black on TC output (right) and shows the extent of inundation based on the third TC component, "wetness." 
Image time $t$

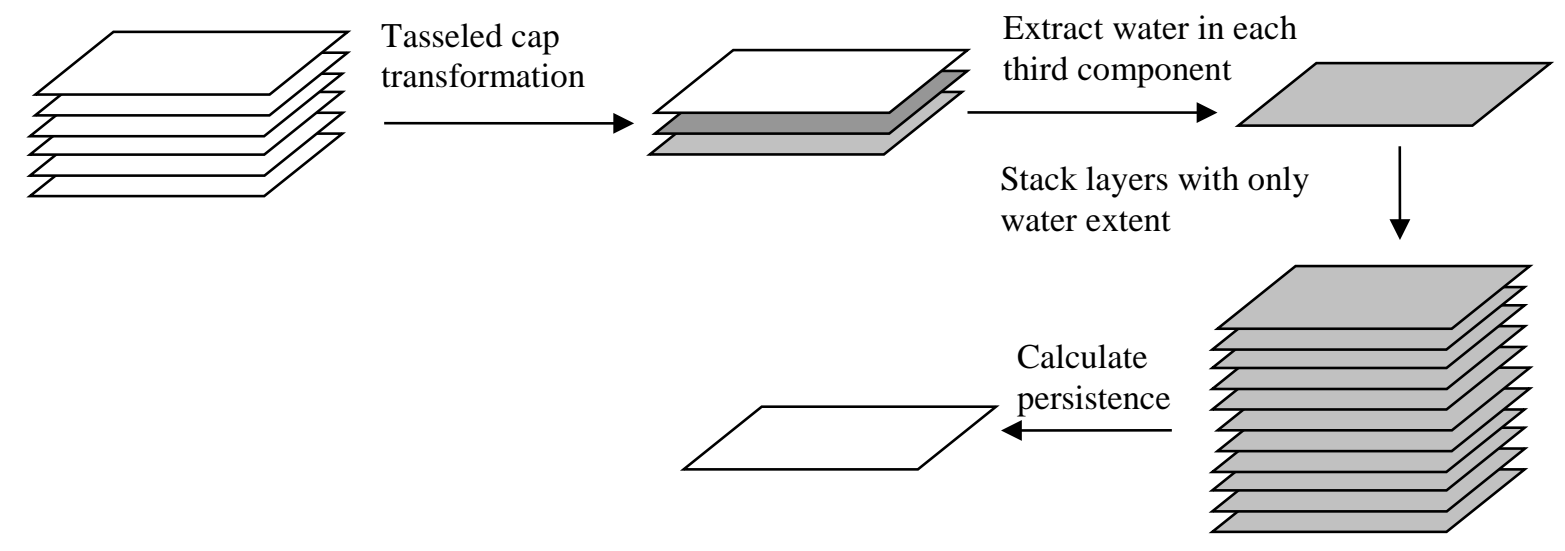

Figure 4. Processing steps to extract inundation for each date and calculate persistence of inundation through time.

The first TC band "brightness" generally explains the majority of the variance in a scene and, as its name implies, is a measure of soil brightness. The second TC band "greenness" explains the second highest amount of variation in the scene and relates to vegetation, as its name implies. The third TC band explains the next highest amount of variability, which is believed to relate to water - including snow and cloud features, and also the interrelationship of soil and canopy moisture - as its name "wetness" implies. The third TC band from each TC scene was used to identify inundation of the playa using a minimum threshold constant of zero. This resulted in a single layer, for each date, with a binary result: water (1) or unclassified (0). For each winter season evaluated, the binary layers were stacked to create one $n$-band data set, where $n$ is the total number of time periods assessed. A sum function was run on this file to generate an output raster showing the spatial persistence of inundation. The output was a single band integer raster. This process is depicted in Figure 4. A composite data set of inundation for all dates analyzed was created by summing the water persistence data sets. This produced a single-band integer raster that identified the number of times water was reported at the pixel level.

Surface area of inundation was calculated as hectares (ha) and meters squared $\left(\mathrm{m}^{2}\right)$. The binary "inundation" raster was exported to vector in ArcGIS shape-file format. Shape files were reviewed in ArcGIS against a topographic base map available online from the Environmental Systems Research Institute, Inc. (www.esri.com) and against all other dates for that winter season. Where an original Landsat scene was identified as being misregistered, manual rectification was done on the original scene using the lowest level transformation possible, and the processing was re-run to completion. Manual masking of clouds in the subset area was done if necessary. A total of 66 scenes were analyzed.

\section{Water Sampling and Analysis}

Water samples were collected from three different locations on March 9, 2010 after most of the water from the inundation in winter 2009-2010 had receded. Sample collection locations were limited to available small pools of water (e.g., Figure 5). Three sets of water 


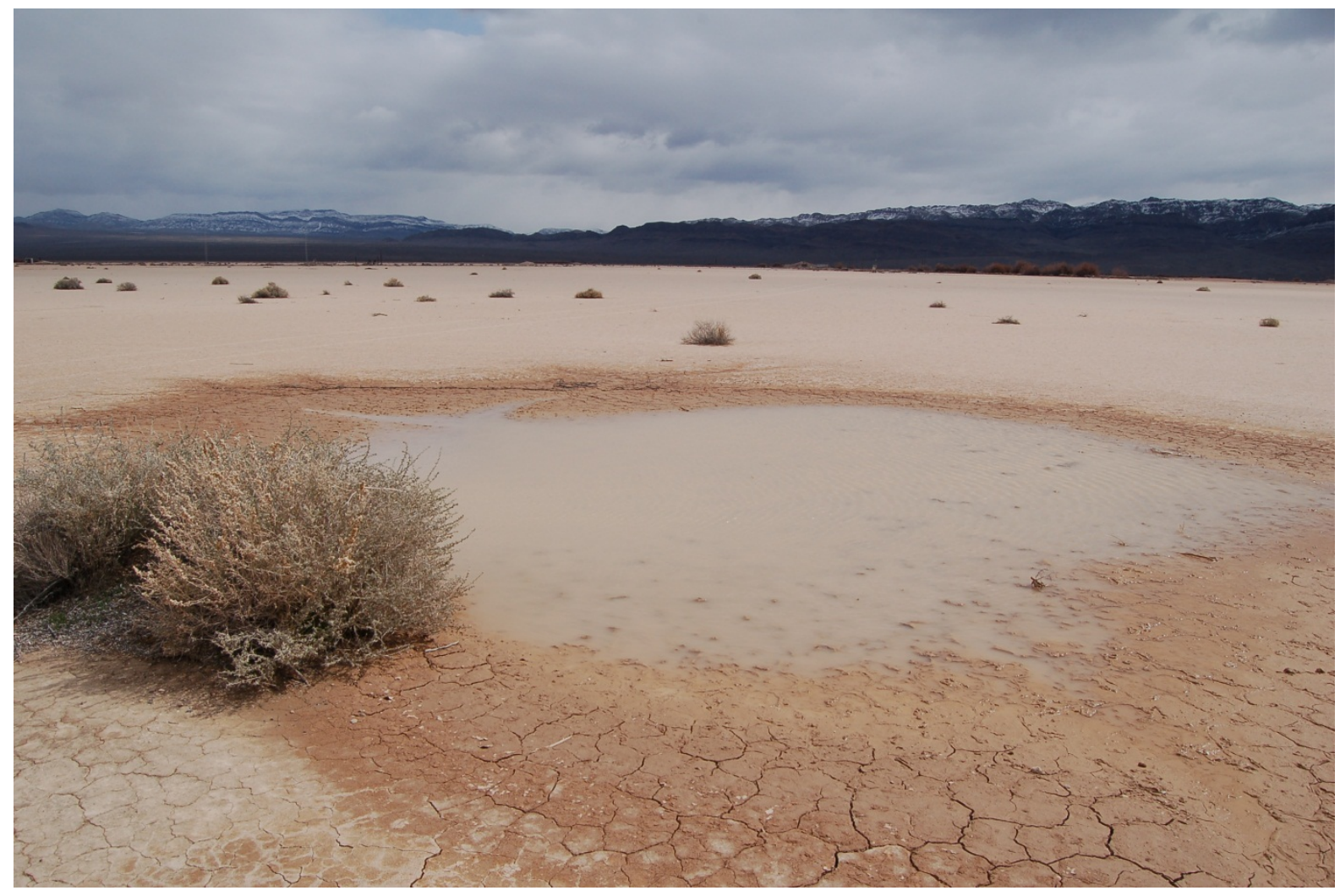

Figure 5. An example of a small residual pool of water on Frenchman Flat playa from winter 20092010. Water samples were collected at this location (\#3) on March 9, 2010.

samples also were collected during winter 2010-2011: January 5, January 26, and February 16. On January 5 , four different sampling locations were selected based upon easy access just off paved roads except for one location, sample January 05, 2011 \#2, which was collected outside the Hamilton Corrective Action Site boundary. Because of the decrease in the extent of inundation between sampling events, only one location, \#1, could be resampled for all three 2011 sampling events. One other location, \#4, was sampled twice, once on January 5 and once on January 16, but this location was dry on February 16. The sample dates, numbers, and locations are listed in Table 1.

Water samples were collected by dipping a plastic beaker into the water on the playa surface and filling either $1 \mathrm{~L}$ or $2 \mathrm{~L}$ plastic bottles and $30 \mathrm{~mL}$ glass vials. Water samples were shipped to the Desert Research Institute (DRI), Reno, Nevada. Water samples were then filtered in the laboratory through $0.45 \mu \mathrm{m}$ filter cartridges. Samples were submitted to the DRI Water Analysis Laboratory for major-ion, fluoride ( $\left.\mathrm{F}^{-}\right)$, bromide (Br $)$, and total dissolved solids (TDS) analyses; to the University of Nevada, Reno Stable Isotopic Laboratory for analysis of hydrogen and oxygen isotopic ratios; and to the University of Nevada, Las Vegas Radioanalytical Service Laboratory for gamma spectroscopy. For gamma spectroscopy, samples, blanks, and detector backgrounds were measured for 24 hours; results were background corrected. 
Table 1. Frenchman Flat playa inundation water sample dates, numbers, and locations.

\begin{tabular}{lcc}
\hline Sample Date & Latitude & Longitude \\
\hline $3 / 9 / 2010 \# 1$ & \multicolumn{2}{c}{ Decimal Degrees } \\
$3 / 9 / 2010 \# 2$ & 36.8060 & 115.9412 \\
$3 / 9 / 2010 \# 3$ & 36.8065 & 115.9362 \\
$1 / 5 / 2011 \# 1^{*}$ & 36.8086 & 115.9463 \\
$1 / 5 / 2011 \# 2$ & 36.7993 & 115.9339 \\
$1 / 5 / 2011 \# 3$ & 36.8020 & 115.9331 \\
$1 / 5 / 2011 \# 4 \wedge$ & 36.7989 & 115.9341 \\
$1 / 26 / 2011 \# 1^{*}$ & 36.8015 & 115.9433 \\
$1 / 26 / 2011 \# 2$ & 36.7994 & 115.9339 \\
$1 / 26 / 2011 \# 3$ & 36.7994 & 115.9369 \\
$1 / 26 / 2011 \# 4 \wedge$ & 36.8016 & 115.9376 \\
$2 / 16 / 2011 \# 1^{*}$ & 36.8016 & 115.9433 \\
$2 / 16 / 2011 \# 2$ & 36.7994 & 115.9339 \\
$2 / 16 / 2011 \# 3$ & 36.7983 & 115.9448 \\
$2 / 16 / 2011 \# 4$ & 36.7992 & 115.9367 \\
\hline
\end{tabular}

* Indicate Samples Collected from the Same Sample Location (year 2011 location \#1)

$\wedge$ Indicates Samples Collected from the Same Sample Location (year 2011 location \#4).

Residual sediment that settled onto the bottom of the sample bottles prior to filtering was retained. Flocculated colloidal material and precipitated minerals that settled onto the bottom of the sample bottles after filtration were also collected and combined with the unfiltered residual sediment. These materials were submitted to the DRI X-Ray Diffraction (XRD) Laboratory for mineralogical identification.

\section{Soil Analysis}

Because soil sampling was not within the scope of this study, two archived Frenchman Flat playa soil samples collected in June, 2000 were analyzed for soil properties. These samples were collected by shovel from several depths: $5-15 \mathrm{~cm}, 15-30 \mathrm{~cm}$, and 30-60 cm; but the exact locations where these samples were collected were not recorded at the time of sampling. Soil samples were submitted to the DRI Soils Laboratory, Reno, Nevada and characterized by Laser Particle Size Analysis for particle size distribution and by XRD for bulk mineral and clay identification. Samples prepared for bulk sample mineral identification were oven dried and dry sieved to $2 \mathrm{~mm}$. The clay and silt fraction for the clay mineral identification and the particle size distribution were wet sieved using distilled water through a $65 \mu \mathrm{m}$ sieve.

Two chemical extractions also were conducted on the soils to quantify the amorphous $\mathrm{Fe}$ and $\mathrm{Al}$ oxides present in the samples. The less than $2 \mathrm{~mm}$ fraction of each sample was used in the citrate-diothionite and hydroxylamine hydrochloride-hydrochloric acid extractions (Loeppert, 1996). The fluid decanted from both extractions was analyzed for Fe and Al using EPA Method 200.8 (ICP-AES) by the DRI Water Analysis Laboratory. An aliquot of the less than $2 \mathrm{~mm}$ fraction also was sent to Micromeritics Analytical Services 
(4356 Communications Dr., Norcross, GA 30093-2901) for surface-area analysis. Surface area was measured using the Brunauer, Emmet, and Teller (BET), $\mathrm{N}_{2}$ (g), surface area analysis.

\section{Geochemical Modeling}

PHREEQC is a computer program that can perform a wide variety of lowtemperature aqueous geochemical calculations (Parkhurst and Appelo, 1999). PHREEQC is based on an ion-association aqueous model and has capabilities for speciation and saturationindex (SI) calculations, batch-reaction, and one-dimensional transport calculations. Reversible reactions that can be modeled include aqueous, mineral, gas, solid-solution, surface-complexation, and ion-exchange equilibria. Irreversible reactions that can be modeled include specified mole transfers of reactants, kinetically controlled reactions, mixing of solutions, and temperature changes. Inverse modeling - finding sets of mineral and gas mole transfers that account for differences in composition between waters, within specified compositional uncertainty limits - also can be performed (Parkhurst and Appelo, 1999).

\section{Water-Chemistry Evolution}

The evolution of water chemistry as water disappeared from the playa was modeled using PHREEQC. Initially, the amounts of different aqueous species based on the measured dissolved concentration of major ions in the playa water samples (e.g., $\mathrm{Ca}^{2+}, \mathrm{CaHCO}_{3}{ }^{+}$, $\mathrm{CaCO}_{3}{ }^{0}, \mathrm{CaSO}_{4}{ }^{0}, \mathrm{CaF}^{+}, \mathrm{CaOH}^{+}, \mathrm{CaHSO}_{4}{ }^{+}$) and the saturation state (under saturated [minerals tend to dissolve], saturated, over saturated [minerals tend to precipitate]) of various minerals were calculated. These calculated data, along with XRD results from the residual sediment, colloidal material, and precipitated minerals, and XRD results from the archived soil samples, were used to construct a set of minerals for modeling changes in water chemistry.

A geochemical mass-balance approach was used to quantify changes in major-ions from one sampling date to the next as the water disappeared. The evolution of the water during inundation was modeled by dissolving or precipitating primary and secondary minerals until the observed water chemistry was matched. Evaporation also was considered in the simulations; the amount of evaporation can be calculated using the Rayleigh distillation equation (Clark, 1997) and the changes in isotopic values of $\delta^{18} \mathrm{O}$ and $\delta^{2} \mathrm{H}$ of water during inundation. The Rayleigh distillation equation uses an exponential function to describe progressive partitioning of the heavier isotopes $\left({ }^{18} \mathrm{O}\right.$ and $\left.{ }^{2} \mathrm{H}\right)$ into water as it disappears.

Model simulations included evaporation and water-mineral reactions involving atmospheric $\mathrm{CO}_{2}$, calcite, halite, gypsum, feldspars (from volcanic rocks), clays (weathering of volcanic rocks), and quartz (Table 2). The chemical composition of the composite feldspars and clays are from the mineralogical characterization of drill core from major aquifers in volcanic terrain in the Pahute Mesa-Oasis Valley flow system (Benedict et al., 2000). The amount of dissolution and precipitation of minerals in the modeling steps was adjusted until the simulated water chemistry matched the final observed water chemistry for a given location and date. 
Table 2. Mineral phases, chemical formulas, and dissolved ions used in geochemical modeling.

\begin{tabular}{|c|c|c|c|}
\hline Mineral Phase & Chemical Formula & Ion Match & $\begin{array}{l}\text { Precipitate } \\
\text { or Dissolve }\end{array}$ \\
\hline $\mathrm{CO}_{2}$ gas & $\mathrm{CO}_{2}$ & $\begin{array}{l}\text { Atmospheric Partial } \\
\text { Pressure }\end{array}$ & $\begin{array}{l}\text { Dissolve or Precipitate } \\
\text { (out gas) }\end{array}$ \\
\hline Calcite & $\mathrm{CaCO}_{3}$ & $\mathrm{Ca}^{2+}$ & Dissolve or Precipitate \\
\hline Halite & $\mathrm{NaCl}$ & $\mathrm{Cl}^{-}$ & Dissolve \\
\hline Gypsum & $\mathrm{CaSO}_{4}$ & $\mathrm{SO}_{4}{ }^{2-}$ & Dissolve \\
\hline $\begin{array}{l}\text { Composite } \\
\text { Feldspar }\end{array}$ & $\begin{array}{l}\mathrm{K}_{0.369} \mathrm{Na}_{0.423} \mathrm{Ca}_{0.026} \mathrm{Mg}_{0.003} \mathrm{Fe}_{0.034} \\
\mathrm{Al}_{0.816} \mathrm{Si}_{4.123} \mathrm{O}_{9.946}\end{array}$ & $\mathrm{~K}^{+}, \mathrm{Na}^{+}$ & Dissolve \\
\hline Composite Clay & $\begin{array}{l}\mathrm{K}_{0.017} \mathrm{Na}_{0.161} \mathrm{Ca}_{0.141} \mathrm{Mg}_{0.138} \mathrm{Fe}_{0.050} \\
\mathrm{Al}_{2.438} \mathrm{Si}_{3.462} \mathrm{O}_{11.024}\end{array}$ & $\mathrm{~K}^{+}, \mathrm{Na}^{+}$ & Precipitate \\
\hline Quartz & $\mathrm{SiO}_{2}$ & $\mathrm{SiO}_{2}$ & Dissolve or Precipitate \\
\hline
\end{tabular}

Radionuclide Sorption and Cation Exchange

Radionuclide mobility in water during inundation was evaluated by modeling surface complexation reactions or cation exchange reactions for several radionuclides. According to Zavarin and Bruton (2004a), a simple non-electrostatic model (NEM) is sufficient to model radionuclide sorption in NNSS groundwater; therefore, a one-site NEM was used to model radionuclide aqueous mobility in this study. Radionuclide sorption onto mineral surfaces was modeled for two common, reactive mineral surfaces, amorphous iron hydroxides, also called hydrous ferric oxides (HFO), and calcite surfaces. Cation exchange was modeled for the clays present in Frenchman Flat playa soils (Zavarin and Bruton, 2004b; Zavarin et al., 2002).

Several radionuclides were selected for modeling during playa inundation since radionuclides are known to be present in soils in Frenchman Flat playa (Figure 2 from DOE, 2010b; DOE, 2010a; McArthur, 1991; McArthur and Mead, 1989; Barnes et al., 1980). Plutonium (Pu) and cesium (Cs) are found in Frenchman Flat playa soils (McArthur, 1991; McArthur and Mead, 1989); Pu is a device component with a very long half-life (Bowen et al., 2001); Cs is a fission product with a long half-life (Bowen et al., 2001). Uranium (U) is an important component found in nuclear devices (e.g., Bowen et al., 2001; DOE, 2010a) and may be present in Frenchman Flat playa soils since aboveground tests were conducted on Frenchman Flat playa (DOE, 2010a); however, it has not been measured in Frenchman Flat playa soils. Depleted U is known to be present at two other sites in Frenchman Flat, 306 GZ and 307 GZ (DOE 2010a). Technetium (Tc), a fission product, is produced when nuclear devices are tested, has a long half-life (Bowen et al., 2001), and is very mobile in the environment (Hu, 2008). Technetium may be present in Frenchman Flat playa soils; but because it is a low-energy beta emitter, its presence has not have been observed with previous sampling and analysis methods (e.g., McArthur, 1991; McArthur and Mead, 1989).

To model U(VI) sorption onto HFO surfaces, surface complexation reactions, aqueous solution species, and reaction constants from Wazne et al. (2003) were used (Table 3). Modeling of Pu(V) onto HFO and calcite surfaces used information from Zavarin et al. (2005) and Zavarin and Bruton (2004a) (Table 4). Reactive site density information for HFO was from Dzombak and Morel (1990) and for calcite from Hinedi et al. (1991). There 
was no information available for Tc(VII) sorption, which is discussed below. Cation exchange capacity (CEC) for clay minerals was from Zavarin et al. (2002). Equilibrium constants for the exchange reactions were the default constants in the PHREEQC database.

Table 3. Aqueous and surface reactions used in uranium surface complexation modeling (Wazne et al., 2003).

\begin{tabular}{lc}
\hline Aqueous Reactions & $\log \mathrm{K}$ \\
\hline $3 \mathrm{UO}_{2}{ }^{2+}+5 \mathrm{H}_{2} \mathrm{O}=5 \mathrm{H}^{+}+\left(\mathrm{UO}_{2}\right)_{3}(\mathrm{OH})_{5}{ }^{+}$ & -15.58 \\
$3 \mathrm{UO}_{2}{ }^{2+}+7 \mathrm{H}_{2} \mathrm{O}=7 \mathrm{H}^{+}+\left(\mathrm{UO}_{2}\right)_{3}(\mathrm{OH})_{7}{ }^{-}$ & -31.00 \\
$\mathrm{UO}_{2}{ }^{2+}+3 \mathrm{H}_{2} \mathrm{O}=3 \mathrm{H}^{+}+\mathrm{UO}_{2}(\mathrm{OH})_{3}{ }^{-}$ & -20.00 \\
$\mathrm{UO}_{2}{ }^{2+}+2 \mathrm{CO}_{3}{ }^{2-}=\mathrm{UO}_{2}\left(\mathrm{CO}_{3}\right)_{2}{ }^{2-}$ & 16.90 \\
$\mathrm{UO}_{2}{ }^{2+}+3 \mathrm{CO}_{3}{ }^{2-}=\mathrm{UO}_{2}\left(\mathrm{CO}_{3}\right)_{3}{ }^{2-}$ & 21.60 \\
$\mathrm{HFO}$ Surface Reactions & \\
\hline HFO-OH $+\mathrm{H}^{+}=>\mathrm{HFO}-\mathrm{OH}_{2}{ }^{+}$ & 6.51 \\
$>\mathrm{HFO}-\mathrm{OH}+\mathrm{H}^{+}=>\mathrm{HFO}-\mathrm{O}^{-}+\mathrm{H}^{+}$ & -9.13 \\
$>\mathrm{HFO}-\mathrm{OH}+\mathrm{CO}_{3}{ }^{2-}+2 \mathrm{H}^{+}=>\mathrm{HFO}^{+} \mathrm{CO}_{3} \mathrm{H}^{0}+\mathrm{H}_{2} \mathrm{O}$ & 18.93 \\
$>\mathrm{HFO}-\mathrm{OH}+\mathrm{CO}_{3}{ }^{2-}+\mathrm{H}^{+}=>\mathrm{HFO}-\mathrm{CO}_{3}{ }^{-}+\mathrm{H}_{2} \mathrm{O}$ & 10.94 \\
$>\mathrm{HFO}-\mathrm{OH}+\mathrm{UO}_{2}{ }^{2+}=>\mathrm{HFO}^{2} \mathrm{O}-\mathrm{UO}_{2}{ }^{+}+\mathrm{H}^{+}$ & 2.00 \\
$>\mathrm{HFO}-\mathrm{OH}+\mathrm{UO}_{2}{ }^{2+}+\mathrm{CO}_{3}{ }^{2-}=>\mathrm{HFO}^{2-O}-\mathrm{UO}_{2} \mathrm{CO}_{3}{ }^{-}+\mathrm{H}^{+}$ & 7.55 \\
$>\mathrm{HFO}-\mathrm{OH}+\mathrm{UO}_{2}{ }^{2+}+2 \mathrm{CO}_{3}{ }^{2-}=>\mathrm{HFO}^{+}-\mathrm{UO}_{2}\left(\mathrm{CO}_{3}\right)_{2}{ }^{3-}+\mathrm{H}^{+}$ & 12.95 \\
\hline
\end{tabular}

Table 4. Aqueous and surface reactions used in plutonium surface complexation modeling (Zavarin and Bruton, 2004a; Zavarin et al., 2005).

\begin{tabular}{|c|c|}
\hline Aqueous Reactions & $\log K$ \\
\hline $\mathrm{PuO}_{2}^{+}+\mathrm{H}_{2} \mathrm{O}=\mathrm{H}^{+}+\mathrm{PuO}_{2} \mathrm{OH}^{0}$ & -9.73 \\
\hline $\mathrm{PuO}_{2}{ }^{+}+\mathrm{HCO}_{3}^{-}=\mathrm{H}^{+}+\mathrm{PuO}_{2} \mathrm{CO}_{3}^{-}$ & -5.21 \\
\hline $\mathrm{PuO}_{2}^{+}+3 \mathrm{HCO}_{3}^{-}=3 \mathrm{H}^{+}+\mathrm{PuO}_{2}\left(\mathrm{CO}^{3}\right)_{3}^{5-}$ & -26.00 \\
\hline \multicolumn{2}{|l|}{ HFO Surface Reactions } \\
\hline$>\mathrm{HFO}-\mathrm{OH}+\mathrm{H}^{+}=>\mathrm{HFO}-\mathrm{OH}_{2}^{+}$ & 7.29 \\
\hline$>\mathrm{HFO}-\mathrm{OH}+\mathrm{H}^{+}=>\mathrm{HFO}^{-} \mathrm{O}^{-}+\mathrm{H}^{+}$ & -8.93 \\
\hline$>\mathrm{HFO}-\mathrm{OH}+\mathrm{PuO}_{2}^{+}=>$HFO-OHPuO ${ }_{2}^{+}$ & 4.79 \\
\hline$>\mathrm{HFO}-\mathrm{OH}+\mathrm{PuO}_{2}{ }^{+}+\mathrm{H}_{2} \mathrm{O}=>\mathrm{HFO}^{-} \mathrm{OHPuO}_{3}{ }^{-}+2 \mathrm{H}^{+}$ & -10.66 \\
\hline \multicolumn{2}{|l|}{ Calcite Surface Reactions } \\
\hline$>\mathrm{CO}_{3} \mathrm{H}=>\mathrm{CO}_{3}^{-}+\mathrm{H}^{+}$ & -5.10 \\
\hline$>\mathrm{CO}_{3} \mathrm{H}+\mathrm{Ca}^{2+}=>\mathrm{CO}_{3} \mathrm{Ca}^{+}+\mathrm{H}^{+}$ & -1.70 \\
\hline$>\mathrm{CaOH}=>\mathrm{CaO}^{-}+\mathrm{H}^{+}$ & -12.0 \\
\hline$>\mathrm{CaOH}+\mathrm{H}^{+}=>\mathrm{CaOH}_{2}^{+}$ & 11.85 \\
\hline$>\mathrm{CaOH}+\mathrm{HCO}_{3}{ }^{-}+\mathrm{H}^{+}=>\mathrm{CaHCO}_{3}{ }^{0}+\mathrm{H}_{2} \mathrm{O}$ & 13.17 \\
\hline$>\mathrm{CaOH}+\mathrm{HCO}_{3}^{-}=>\mathrm{CaCO}_{3}^{-}+\mathrm{H}_{2} \mathrm{O}$ & 6.77 \\
\hline$>\mathrm{Ca}++\mathrm{PuO}_{2}{ }^{+}+2 \mathrm{HCO}_{3}{ }^{-}=>\mathrm{CaCO}_{3} \mathrm{PuO}_{2} \mathrm{CO}_{3}{ }^{2}-+2 \mathrm{H}^{+}$ & -1.40 \\
\hline
\end{tabular}




\section{RESULTS AND DISCUSSION}

\section{Duration and Extent of Playa Inundation}

Frenchman Flat playa was inundated during the winters of 2010-2011 and 2009-2010; the monthly precipitation totals for the winter months of those years at the W5b weather station were reviewed. Winter was assumed to be November through April. The winter of 2010-2011 had only one month of substantial rainfall, December $(8.71 \mathrm{~cm})$ while the winter of 2009-2010 had three consecutive months of substantial rainfall: December $(1.78 \mathrm{~cm})$, January $(3.63 \mathrm{~cm})$, and February $(2.34 \mathrm{~cm})$.

\section{Winter 2010-2011}

A large amount of precipitation was recorded at the W5b weather station in Frenchman Flat in December 2010 (Table 5). Precipitation during the other winter months of 2010-2011 was less than $1.0 \mathrm{~cm}$ per month.

Table 5. Monthly total precipitation at the W5b weather station in Frenchman Flat for the winter of 2010-2011.

\begin{tabular}{lllllll}
\hline Month & Nov & Dec & Jan & Feb & Mar & Apr \\
\hline $\begin{array}{l}\text { Precipitation } \\
(\mathrm{cm})\end{array}$ & 0.41 & 8.71 & 0.43 & 0.56 & 0.74 & 0.00 \\
\hline
\end{tabular}

A total of nine Landsat scenes were processed for the time period November 2010April 2011, all showing inundation of the playa based on the image analysis; however, the amount of inundation for November 22, 2010 and April 15, 2011 was very small (Table 6). Rainfall in October, $2011(4.71 \mathrm{~cm})$ apparently was sufficient to produce some inundation of the playa seen in the November 22, 2011, image. Earlier Landsat scenes from October and November were not processed. The total surface area of inundation by date is presented in Table 6 . The persistence of inundation of the playa was calculated by summing each pixel on every processed scene that showed inundation. Figure 6 shows persistence of inundation for the winter of 2010-2011. The lighter blue colors show pixels where inundation existed for shorter periods of time while the darker blue colors show pixels that were inundated for longer periods of time. The scenes closest to the sampling dates are presented in Figures 7 through 9; these scenes show the extent of inundation at about the time of collection of each water sample and the location of each water sample. Scenes showing the extent of inundation for the other dates in the winter of 2010-2011 are presented in Appendix A. 
Table 6. Total surface area of inundation on Frenchman Flat playa by Landsat scene for the winter of 2010-2011.

\begin{tabular}{crr}
\hline Date & ha & $\mathbf{m}^{\mathbf{2}}$ \\
\hline $11 / 22 / 2010$ & 0.63 & 6,300 \\
$12 / 24 / 2010$ & 727.38 & $7,273,800$ \\
$1 / 9 / 2011$ & 798.03 & $7,980,300$ \\
$1 / 25 / 2011$ & 223.74 & $2,237,400$ \\
$2 / 10 / 2011$ & 17.46 & 174,600 \\
$2 / 26 / 2011$ & 13.50 & 135,000 \\
$3 / 14 / 2011$ & 7.29 & 72,900 \\
$3 / 30 / 2011$ & 3.96 & 39,600 \\
$4 / 15 / 2011$ & 0.72 & 7,200 \\
\hline
\end{tabular}

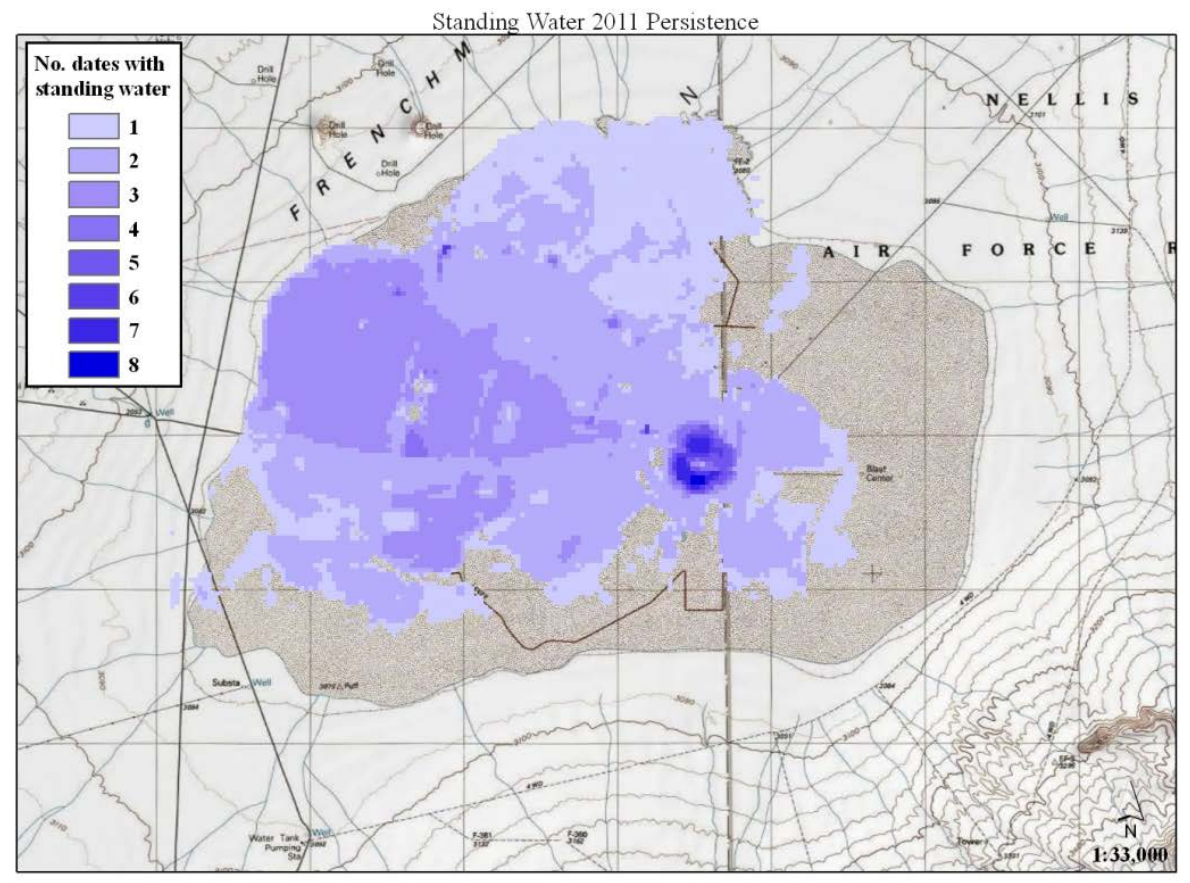

Figure 6. Persistence of inundation on Frenchman Flat playa for the winter of 2010-2011.

Persistence was calculated by summing each pixel on every Landsat scene (each scene date) that had water. The light blue colors show pixels where water existed for shorter time periods while the dark blue colors show pixels that had water for longer time periods. The inundation for November 22, 2010 is not included. 


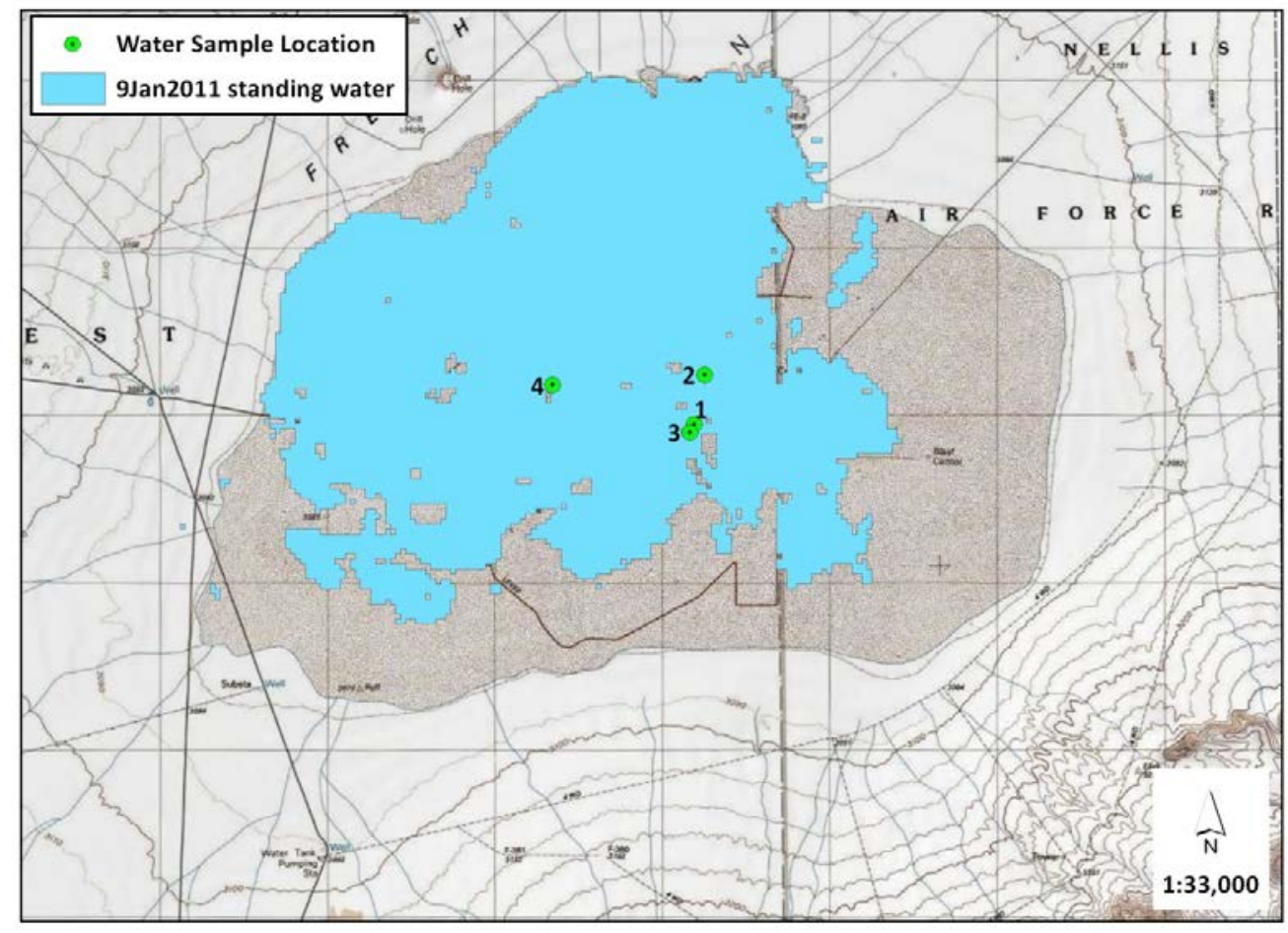

Figure 7. Extent of inundation and water sampling locations on Frenchman Flat playa for the Landsat scene on January 9, 2011. Water samples were collected on January 5, 2011.

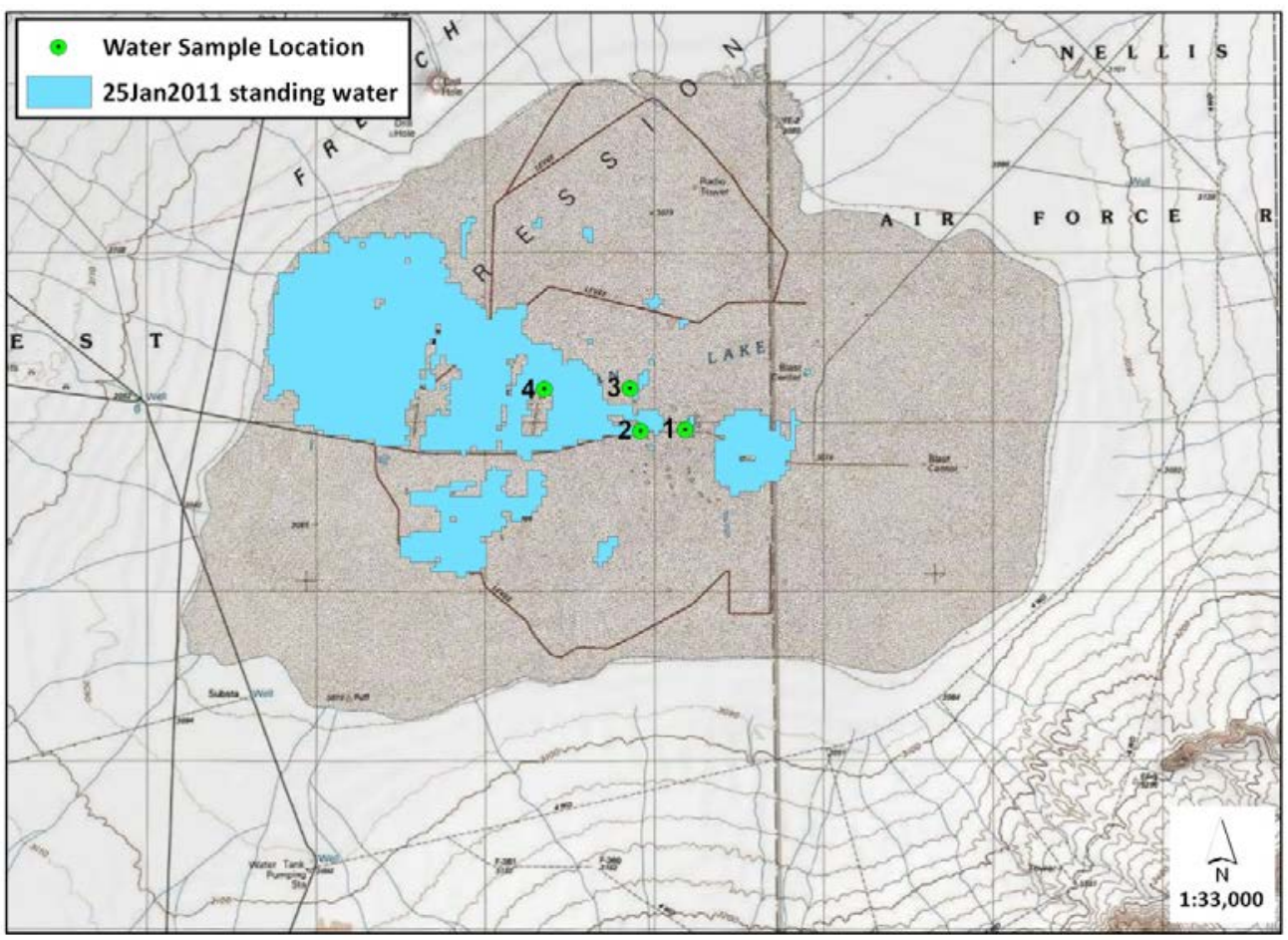

Figure 8. Extent of inundation and water sampling locations on Frenchman Flat playa for the Landsat scene on January 25, 2011. Water samples were collected on January 26, 2011. 


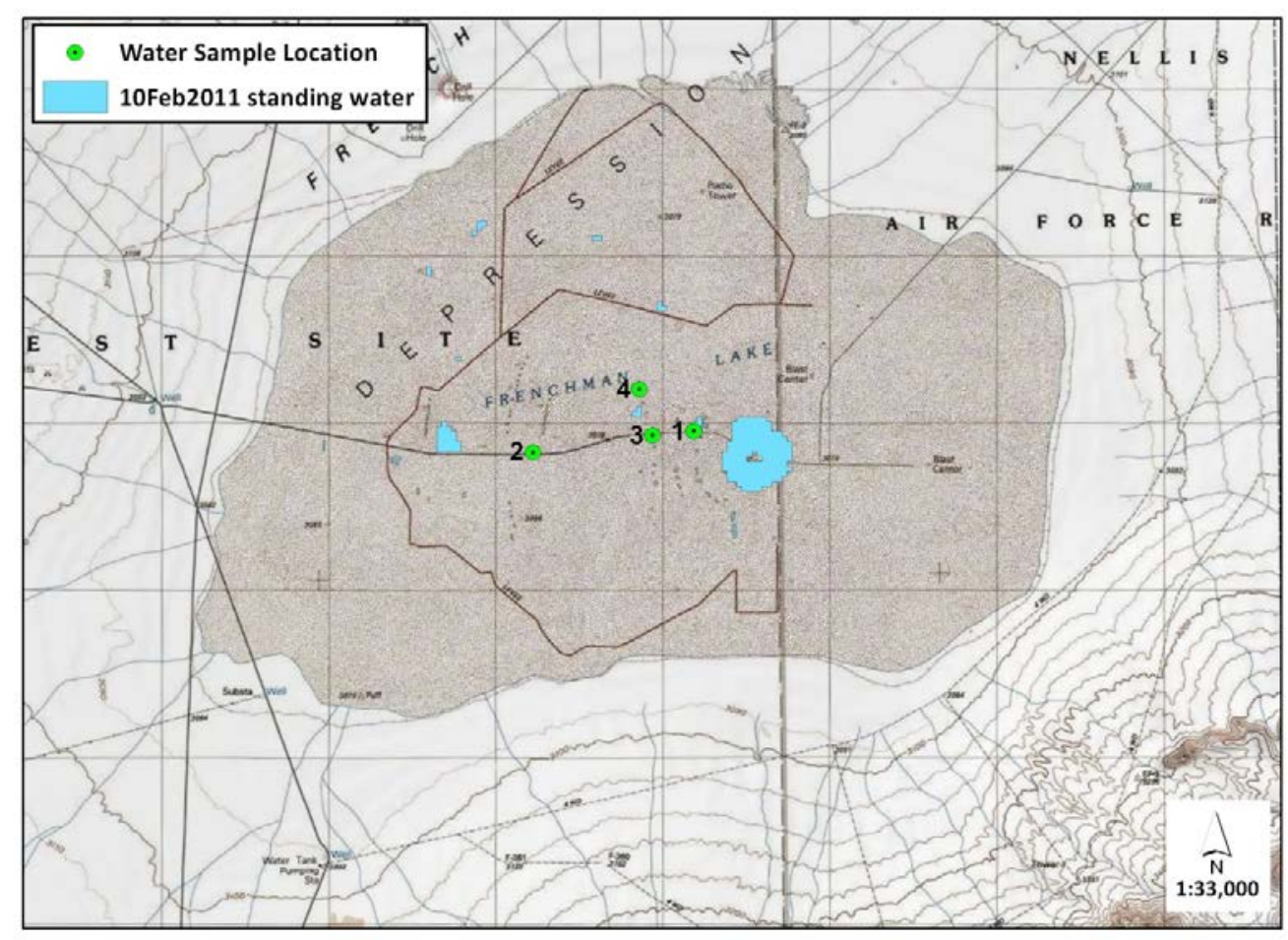

Figure 9. Extent of inundation and water sampling locations on Frenchman Flat playa for the Landsat scene on February 10, 2011. Water samples were collected on February 16, 2011. Water samples were collected from small pools of water.

Winter 2009-2010

Significant precipitation was recorded at the W5b weather station between December, 2009 and February, 2010 (Table 7). Precipitation during the other winter months of 20092010 was less than $1.00 \mathrm{~cm}$ per month.

Table 7. Monthly total precipitation at the W5b weather station in Frenchman Flat for the winter of 2009-2010.

\begin{tabular}{lllllll}
\hline Month & Nov & Dec & Jan & Feb & Mar & Apr \\
\hline $\begin{array}{l}\text { Precipitation } \\
(\mathrm{cm})\end{array}$ & 0.25 & 1.78 & 3.63 & 2.34 & 0.58 & 0.38 \\
\hline
\end{tabular}

A total of seven Landsat scenes were processed for the time period November, 2009 through April, 2010; four scenes showed inundation on the playa based on the image analysis. The estimate for January 22, 2010 is questionable since there was some cloud cover over the playa that might have affected the results by overestimating inundation; but without ground truth data, this result cannot be verified. The total surface area of inundation by date is presented in Table 8. Figure 10 shows persistence of inundation for the winter of 20092010. Figure 11 shows the extent of inundation on March 11, 2010; water samples were collected on March 9. Scenes showing the extent of inundation for the other dates are presented in Appendix A. 
Table 8. Total surface area of inundation on Frenchman Flat playa by Landsat scene for the winter of 2009-2010.

\begin{tabular}{crr}
\hline Date & ha & $\mathbf{m}^{2}$ \\
\hline $11 / 3 / 2009$ & 0.00 & 0 \\
$11 / 19 / 2009$ & 0.00 & 0 \\
$1 / 22 / 2010$ & 823.95 & $8,239,500$ \\
$3 / 11 / 2010$ & 5.94 & 59,400 \\
$3 / 27 / 2010$ & 1.98 & 19,800 \\
$4 / 12 / 2010$ & 0.45 & 4,500 \\
$4 / 28 / 2010$ & 0.00 & 0 \\
\hline
\end{tabular}

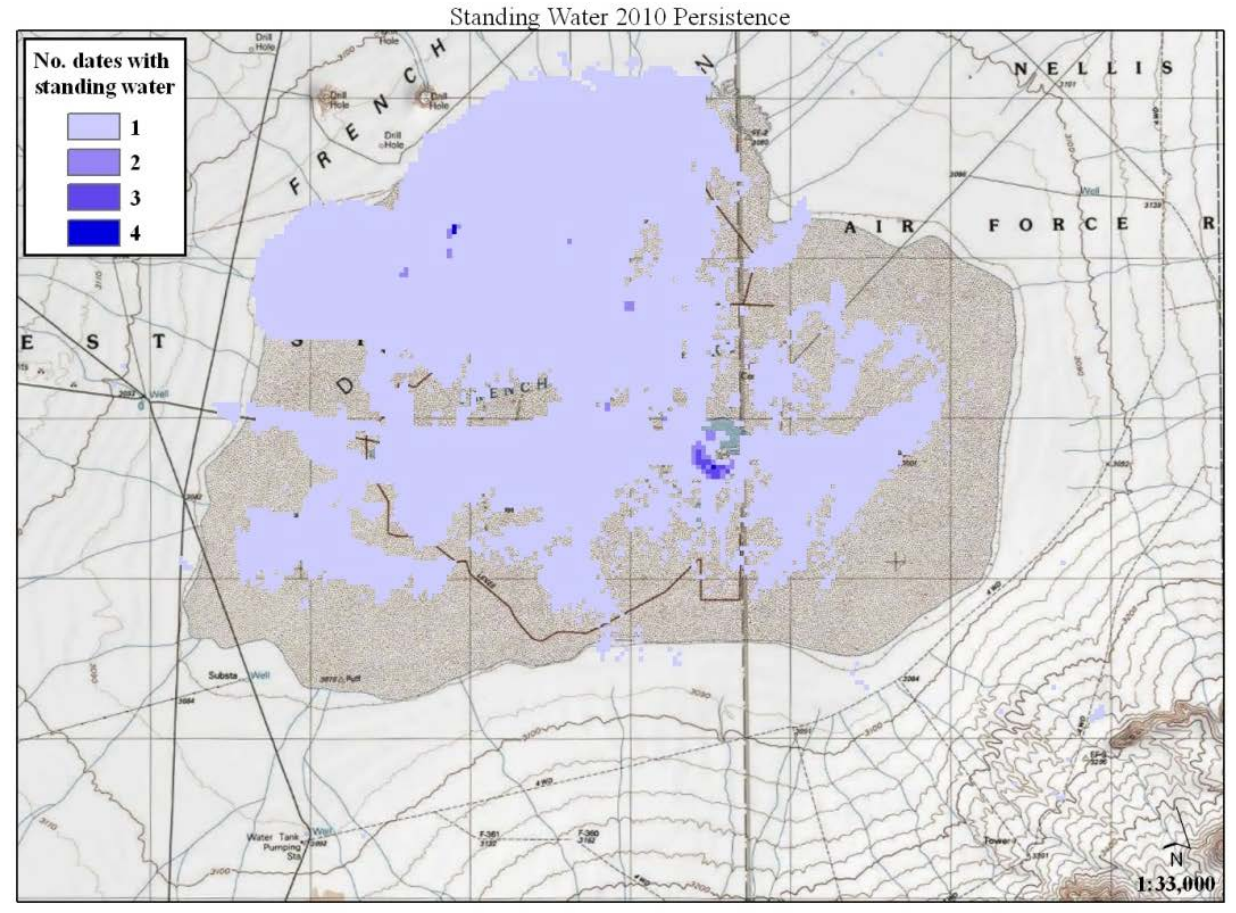

Figure 10. Persistence of inundation on Frenchman Flat playa for the winter of 2009-2010. Persistence was calculated by summing each pixel on every Landsat scene (each scene date) that was inundation. The light blue colors show pixels where water existed for shorter time periods while the dark blue colors show pixels that were inundated for longer time periods. 


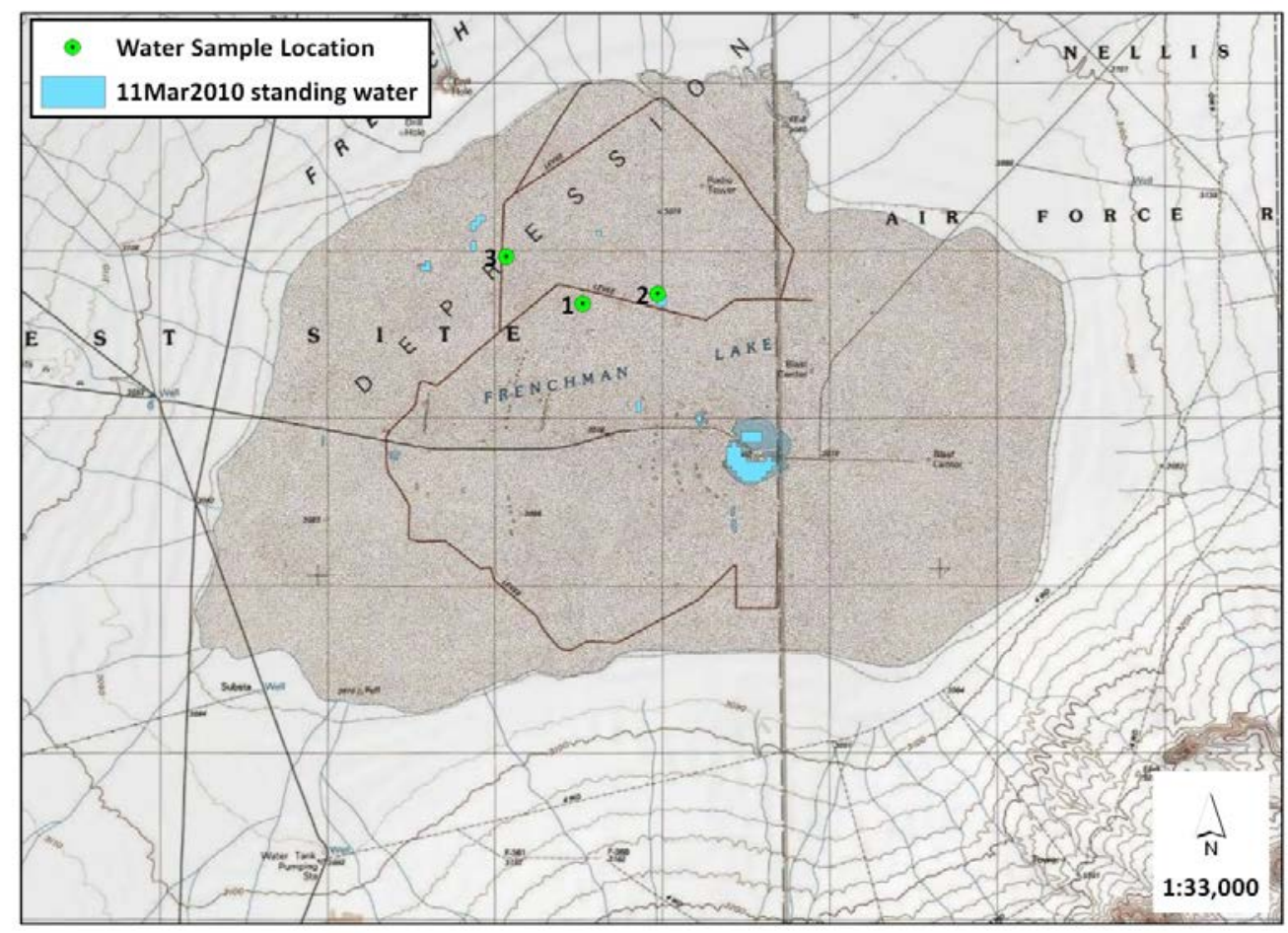

Figure 11. Extent of inundation and water sampling locations on Frenchman Flat playa for the Landsat scene on March 11, 2010. Water samples were collected on March 9, 2010. Water samples were collected from small puddles of water.

\section{Playa Water Chemistry}

Fifteen water samples were collected and analyzed for chemical constituents for this investigation. Three samples were collected from small pools of water at three different locations in March 2010 after most of the water on the playa had disappeared. Twelve samples were collected in January and February 2011 during three different sampling events at multiple locations. Initially, four different sampling locations were selected on January 5, 2011. Because the extent of the inundation decreased between sampling events, only one location (\#1) could be resampled during all three sampling events. Another location (\#4) could be sampled only twice; this location was dry on the last sampling event. For the last sampling event, February 16, 2011, three of the four samples were limited to available small pools that were at different locations on the playa from previous sampling events.

\section{Major-Ions}

Results of major-ion analyses are listed in Table 9. Major-ion chemistry was predominantly calcium $\left(\mathrm{Ca}^{2+}\right)$ and sodium $\left(\mathrm{Na}^{+}\right)$cations with bicarbonate $\left(\mathrm{HCO}_{3}{ }^{-}\right)$anions (Figure 12). Total dissolved solids are a measure of the dissolved constituents in water during playa inundation; TDS concentrations increased roughly threefold during the winter of 20102011 as the water disappeared (Table 9) while chloride-ions $\left(\mathrm{Cl}^{-}\right)$increased about fourfold. Arrows in Figure 13 show changes in TDS and $\mathrm{Cl}^{-}$through time at the same sampling locations. Increases in TDS and $\mathrm{Cl}^{-}$as the extent of inundation decreased generally suggest that the water is evaporating and dissolving soil minerals. 
Table 9. Major-ion chemistry of Frenchman Flat playa water samples.

\begin{tabular}{|c|c|c|c|c|c|c|c|c|c|c|c|c|c|c|c|}
\hline $\begin{array}{c}\text { Sample } \\
\text { Name }\end{array}$ & $\mathbf{p H}$ & $\begin{array}{c}\text { EC } \\
(\mathrm{mS} / \mathrm{cm})\end{array}$ & $\begin{array}{c}\mathrm{SiO}_{2} \\
(\mathrm{mg} / \mathrm{L})\end{array}$ & $\begin{array}{l}\mathrm{HCO}_{3} \\
(\mathrm{mg} / \mathrm{L})\end{array}$ & $\begin{array}{c}\mathrm{CO}_{3} \\
(\mathrm{mg} / \mathrm{L})\end{array}$ & $\begin{array}{c}\mathrm{Cl} \\
(\mathrm{mg} / \mathrm{L})\end{array}$ & $\begin{array}{c}\mathrm{SO}_{4} \\
(\mathrm{mg} / \mathrm{L})\end{array}$ & $\begin{array}{c}\mathrm{NO}_{3} \\
(\mathrm{mg} / \mathrm{L})\end{array}$ & $\begin{array}{c}\mathrm{Na} \\
(\mathrm{mg} / \mathrm{L})\end{array}$ & $\begin{array}{c}\mathrm{K} \\
(\mathrm{mg} / \mathrm{L})\end{array}$ & $\begin{array}{c}\mathrm{Ca} \\
(\mathrm{mg} / \mathrm{L})\end{array}$ & $\begin{array}{c}\mathrm{Mg} \\
(\mathrm{mg} / \mathrm{L})\end{array}$ & $\begin{array}{c}\mathbf{F} \\
(\mathrm{mg} / \mathrm{L})\end{array}$ & $\begin{array}{c}\mathrm{Br} \\
(\mathrm{mg} / \mathrm{L})\end{array}$ & $\begin{array}{c}\text { TDS } \\
(\mathrm{mg} / \mathrm{L})\end{array}$ \\
\hline 3/9/2010 \#1 & 8.22 & 277 & 6.7 & 178 & NA & 0.84 & 4.58 & 0.017 & 18.4 & 10.8 & 29.1 & 5.70 & 0.23 & $<0.01$ & 172 \\
\hline 3/9/2010 \#2 & 8.33 & 245 & 3.4 & 152 & 1.0 & 1.16 & 2.90 & 0.008 & 30.1 & 11.5 & 13.6 & 4.21 & 0.26 & 0.02 & 154 \\
\hline 3/9/2010 \#3 & 8.32 & 251 & 0.9 & 155 & 0.8 & 0.92 & 2.92 & 0.008 & 38.9 & 10.6 & 10.0 & 3.58 & 1.41 & 0.01 & 162 \\
\hline 1/5/2011 \#1 & 8.31 & 88 & 4.1 & 40.4 & 2.4 & 0.6 & 2.0 & 0.01 & 8.47 & 4.93 & 5.92 & 0.92 & 0.16 & $<0.02$ & 44 \\
\hline 1/5/2011 \#2 & 9.68 & 100 & 7.2 & 23.5 & 15.1 & 0.6 & 2.1 & $<0.01$ & 10.2 & 5.55 & 6.32 & 0.97 & 0.20 & $<0.02$ & 55 \\
\hline 1/5/2011 \#3 & 9.66 & 65 & 5.2 & 15.6 & 9.1 & 0.5 & 1.2 & $<0.01$ & 6.74 & 3.40 & 3.62 & 0.41 & 0.14 & $<0.02$ & 37 \\
\hline 1/5/2011 \#4 & 8.63 & 79 & 2.2 & 32.7 & 1.0 & 0.7 & 4.8 & 0.84 & 7.16 & 3.45 & 6.76 & 0.68 & 0.13 & $<0.02$ & 47 \\
\hline 1/26/2011 \#1 & 7.86 & 170 & 4.5 & 98.6 & NA & 1.2 & 4.9 & 0.02 & 11.2 & 8.08 & 18.0 & 2.44 & 0.11 & $<0.02$ & 99 \\
\hline 1/26/2011 \#2 & 8.30 & 229 & 4.0 & 139 & NA & 1.6 & 4.5 & $<0.01$ & 28.2 & 12.5 & 14.4 & 3.16 & 0.27 & $<0.02$ & 135 \\
\hline 1/26/2011 \#3 & 9.01 & 171 & 2.7 & 78 & 8.6 & 1.6 & 7.2 & $<0.01$ & 21.9 & 9.42 & 9.8 & 2.18 & 0.28 & $<0.02$ & 107 \\
\hline 1/26/2011 \#4 & 8.64 & 269 & 4.5 & 153 & 5.1 & 2.3 & 5.4 & $<0.01$ & 35.7 & 13.2 & 14.1 & 3.27 & 0.32 & $<0.02$ & 160 \\
\hline 2/16/2011 \#1 & 8.06 & 214 & 5.3 & 126 & NA & 1.3 & 5.8 & 0.095 & 11.5 & 8.8 & 25.8 & 3.11 & 0.11 & 0.01 & 130 \\
\hline 2/16/2011\#2 & 8.26 & 316 & 8.3 & 194 & NA & 2.6 & 7.6 & 0.005 & 25.4 & 11.9 & 29.3 & 6.53 & 0.19 & $<0.01$ & 176 \\
\hline 2/16/2011 \#3 & 8.27 & 344 & 1.8 & 215 & NA & 2.9 & 6.1 & 0.045 & 37.4 & 15.6 & 21.6 & 6.95 & 0.18 & 0.02 & 190 \\
\hline 2/16/2011 \#4 & 8.24 & 275 & 0.8 & 146 & NA & 2.7 & 15.8 & 0.006 & 34.8 & 12.4 & 13.0 & 4.55 & 0.24 & 0.02 & 145 \\
\hline
\end{tabular}


However, TDS and $\mathrm{Cl}^{-}$concentrations were still quite low (TDS $<200$ milligrams per liter [mg/L]; $\mathrm{Cl}^{-}<3.0 \mathrm{mg} / \mathrm{L}$ ) considering that 98 to 99 percent of the water on the playa had disappeared (percent determined by dividing the surface area remaining at the time of sampling by the maximum surface area from Landsat imagery analysis; Table 6 and Table 8). Taking any of the dilute water samples from January 5, 2011 and concentrating them by removing 98 percent of the water (excluding mineral precipitation) produces water with a TDS greater than 3,000 mg/L and a $\mathrm{Cl}^{-}$concentration more than $60 \mathrm{mg} / \mathrm{L}$; much higher concentrations than observed in any of the March 9, 2010 or February 16, 2011 samples. The very low TDS and $\mathrm{Cl}^{-}$concentrations in water samples during inundation suggest that evaporation is not the only process removing water from the playa; otherwise, concentrations in residual water on the playa would be substantially higher.

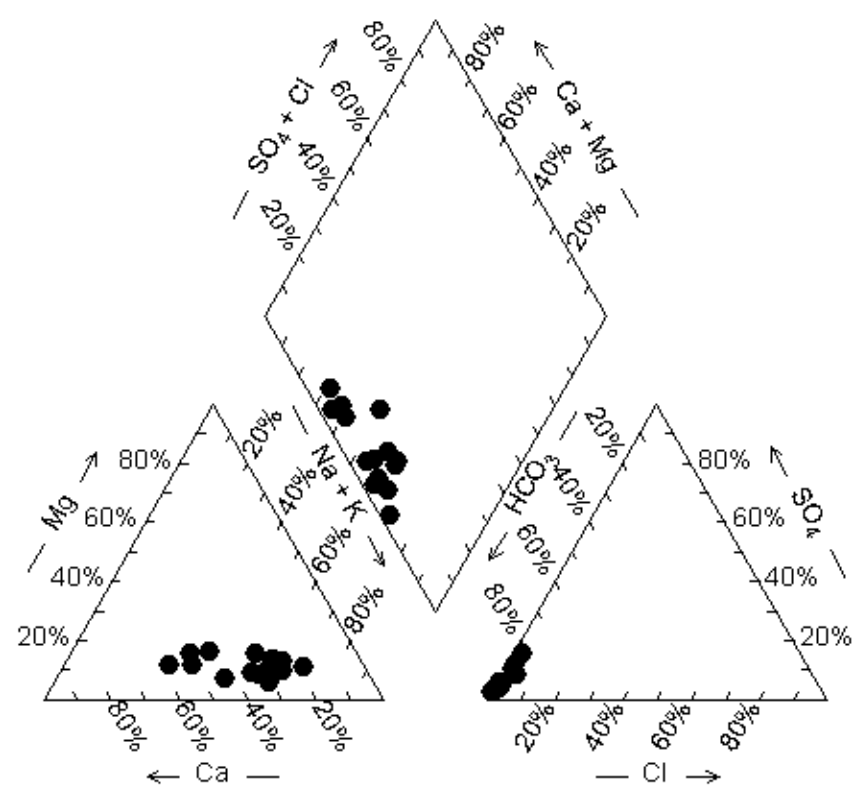

Figure 12. Major-ion diagram of water samples during inundation of Frenchman Flat playa from March 2010, January 2011, and February 2011. Major-ion chemistry was predominantly $\mathrm{Ca}^{2+}$ and $\mathrm{Na}^{+}$cations with $\mathrm{HCO}_{3}{ }^{-}$anions. 


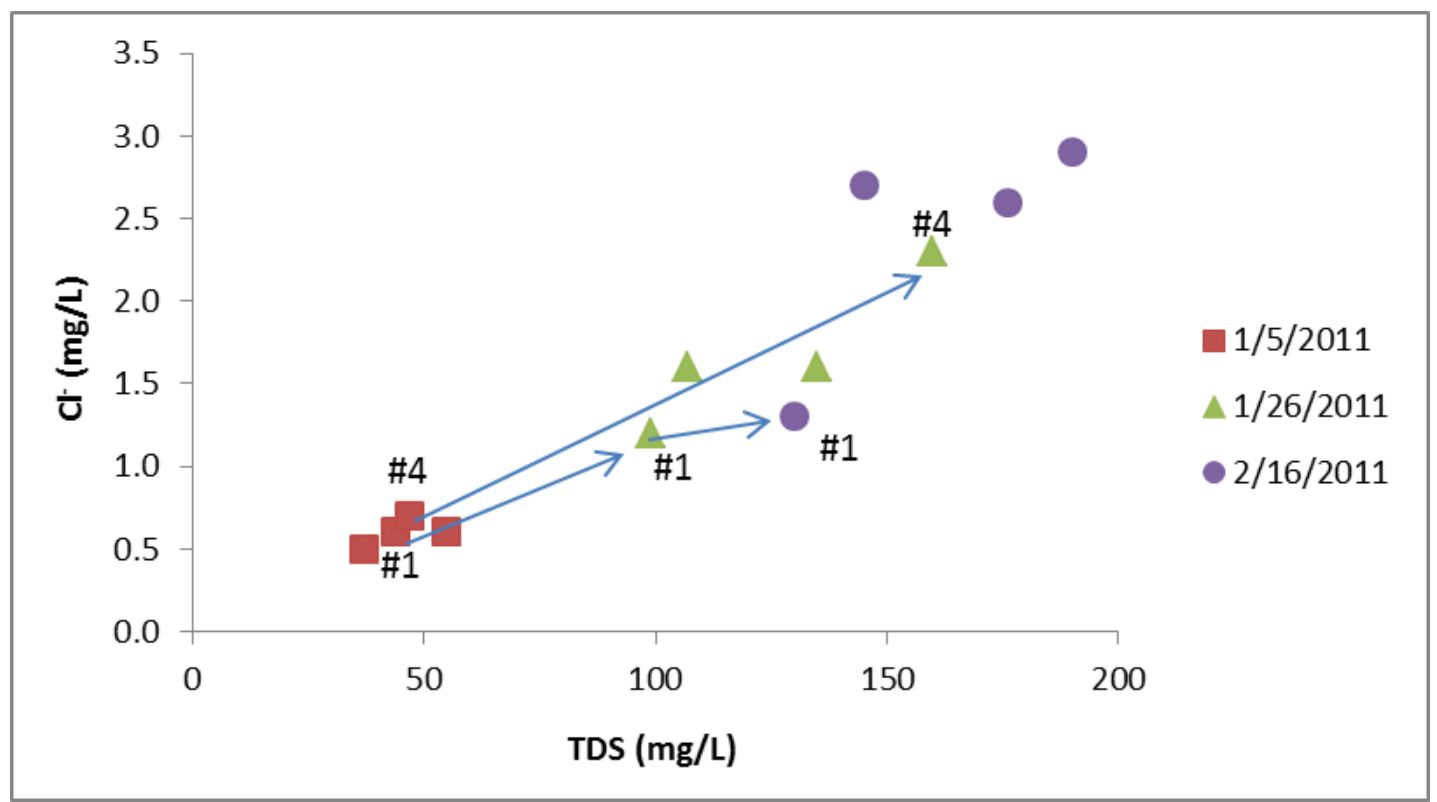

Figure 13. $\mathrm{Cl}^{-}$vs. TDS for water samples during inundation of Frenchman Flat playa. Arrows show changes in TDS and $\mathrm{Cl}^{-}$through time at the same sampling locations. Other samples were collected at different locations at different times because previous sampling locations went dry and could not be resampled at later dates.

\section{Hydrogen and Oxygen Isotopes}

Hydrogen and oxygen are part of the water molecule; changes in their isotopic ratios $\left({ }^{2} \mathrm{H} /{ }^{1} \mathrm{H}\right.$ and $\left.{ }^{18} \mathrm{O} /{ }^{16} \mathrm{O}\right)$, expressed as $\delta^{2} \mathrm{H}$ and $\delta^{18} \mathrm{O}$ in the unit per mil with the symbol \%o, can be used to determine the amount of evaporation of surface waters (Fritz and Clark, 1997). Isotopes fractionate (separate) during phase changes because of mass differences between the isotopes. For example, when water evaporates, the heavier isotopes tend to stay in the denser phase (in this case, the liquid water phase) so the residual water gets isotopically heavier. Analytically, isotopic ratios of hydrogen and oxygen are compared to a standard (Vienna Standard Mean Ocean Water [VSMOW]), which has a predetermined isotopic $\delta$ value of $0.0 \%$ (Fritz and Clark, 1997). Table 10 shows the $\delta^{2} \mathrm{H}$ and $\delta^{18} \mathrm{O}$ values of water samples during inundation of Frenchman Flat playa collected in the winter of 2009-2010 and 20102011. All of these isotopic values were negative meaning they were all depleted of the heavier isotopes $\left({ }^{2} \mathrm{H}\right.$ and $\left.{ }^{18} \mathrm{O}\right)$ relative to ocean water, typical for precipitation over continents. As the water on the playa disappeared, the residual water became progressively heavier isotopically, which resulted in the $\delta$ values becoming less negative. That is, the water was getting isotopically closer to the $\delta$ value of ocean water and isotopically further away from the initial isotopic signature of precipitation that caused inundation of the playa.

The $\delta^{2} \mathrm{H}$ and $\delta^{18} \mathrm{O}$ of water samples collected in the winters of 2009-2010 and 20102011 are presented in Figure 14. The local meteoric water line (LMWL) is plotted for reference; it is an average of precipitation $\left(\delta^{2} \mathrm{H}=6.87 \delta^{18} \mathrm{O}-6.5\right)$ collected from 14 different locations at the NNSS from 1982 through 1986 (Ingraham et al., 1991). Generally, the $\delta^{2} \mathrm{H}$ and $\delta^{18} \mathrm{O}$ values of water samples during inundation show increased evaporation through time as $\delta^{2} \mathrm{H}$ and $\delta^{18} \mathrm{O}$ values plot farther away from the LMWL. 
Table 10. $\quad \delta^{2} \mathrm{H}$ and $\delta^{18} \mathrm{O}$ of water samples collected in the winters of 2009-2010 and 2010-2011from Frenchman Flat playa during inundation.

\begin{tabular}{lcc}
\hline Sample Name & $\boldsymbol{\delta}^{\mathbf{1 8}} \mathbf{O}_{\text {VSMOW }} \mathbf{( \% o )}$ & $\boldsymbol{\delta}^{\mathbf{2}} \mathbf{H}_{\text {VsMow }} \mathbf{( \% o )}$ \\
\hline $3 / 9 / 2010 \# 1$ & -9.5 & -82 \\
$3 / 9 / 2010 \# 2$ & -3.0 & -48 \\
$3 / 9 / 2010 \# 3$ & -0.6 & -35 \\
$1 / 5 / 2011 \# 1$ & -18.0 & -139 \\
$1 / 5 / 2011 \# 2$ & -18.1 & -141 \\
$1 / 5 / 2011 \# 3$ & -16.2 & -126 \\
$1 / 5 / 2011 \# 4$ & -16.5 & -130 \\
$1 / 26 / 2011 \# 1$ & -18.3 & -139 \\
$1 / 26 / 2011 \# 2$ & -11.0 & -103 \\
$1 / 26 / 2011 \# 3$ & -10.3 & -100 \\
$1 / 26 / 2011 \# 4$ & -9.0 & -93 \\
$2 / 16 / 2011 \# 1$ & -17.9 & -138 \\
$2 / 16 / 2011 \# 2$ & -13.5 & -117 \\
$2 / 16 / 2011 \# 3$ & -8.4 & -94 \\
$2 / 16 / 2011 \# 4$ & -2.5 & -62 \\
\hline
\end{tabular}

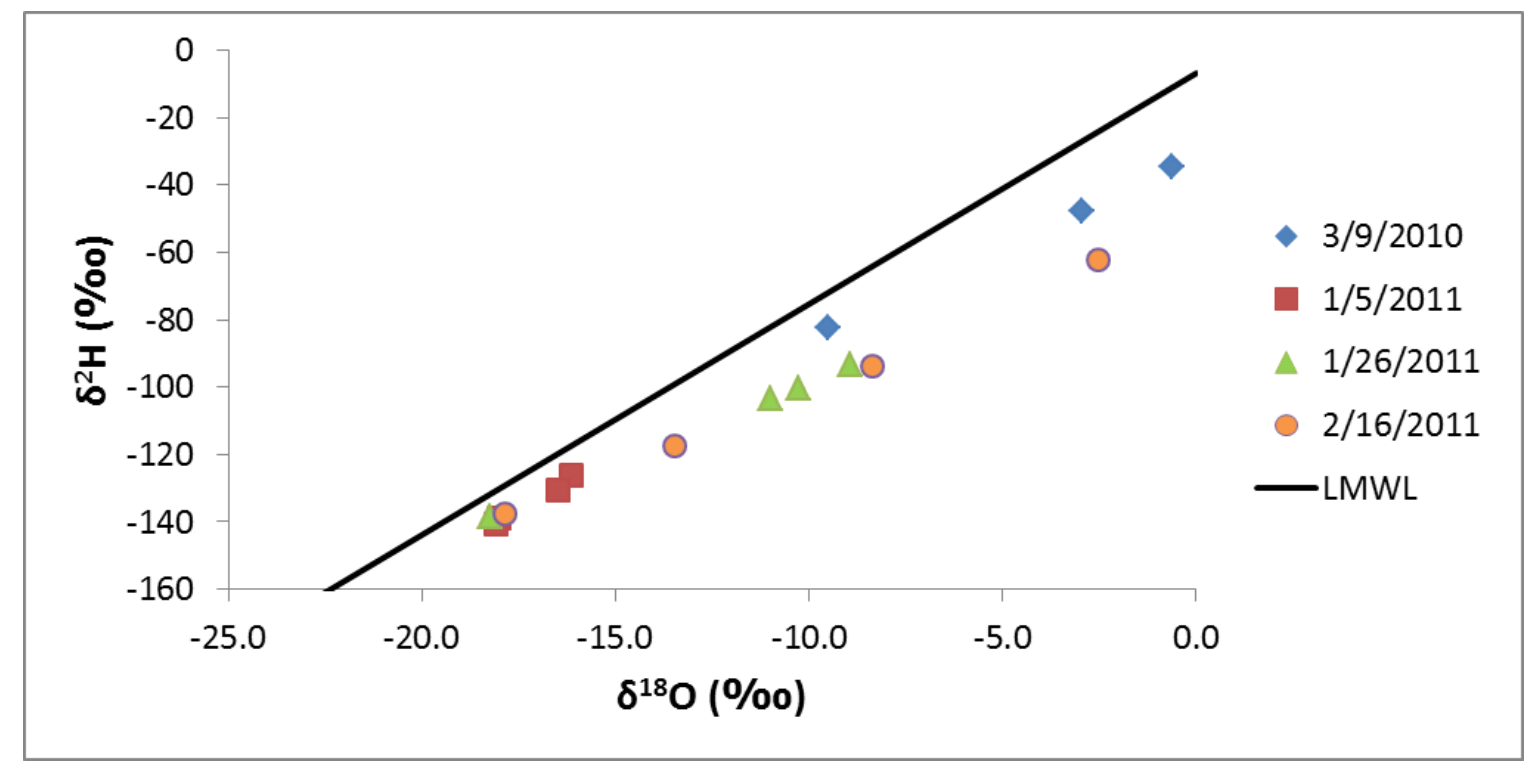

Figure 14. $\delta^{2} \mathrm{H}$ and $\delta^{18} \mathrm{O}$ of water samples collected in the winters of 2009-2010 and 2010-2011from Frenchman Flat playa during inundation. The local meteoric water line is shown for reference (LMWL; $\delta^{2} \mathrm{H}=6.87 \delta^{18} \mathrm{O}-6.5$; Ingraham et al., 1991). 
Evaporation of a water body will show progressive enrichment of isotopic values (values become less negative to positive) as water is removed because the heavier isotopes tend to stay in the remaining water. When inundation of the playa was extensive in the winter of 2010-2011, the isotopic signature of the water samples from January 5, 2011 was relatively homogenous (Table 10; Figure 15 and 16), and close to the average isotopic signature of precipitation that caused the inundation (samples plot close to the LMWL). As the inundation receded and different areas of water became isolated from each other, the isotopic signature of individual pools of water began to vary. This variation in isotopic signature results from differences in the depth and/or surface area of each pool. Shallow pools with greater surface area will evaporate faster than pools with less surface area; deeper pools with greater volume will take longer to evaporate, therefore, will have less isotopic enrichment relative to pools that have lost more of their total volume during the same time period. This variation was evident when comparing water samples collected from the same location at different times as water receded from the playa.

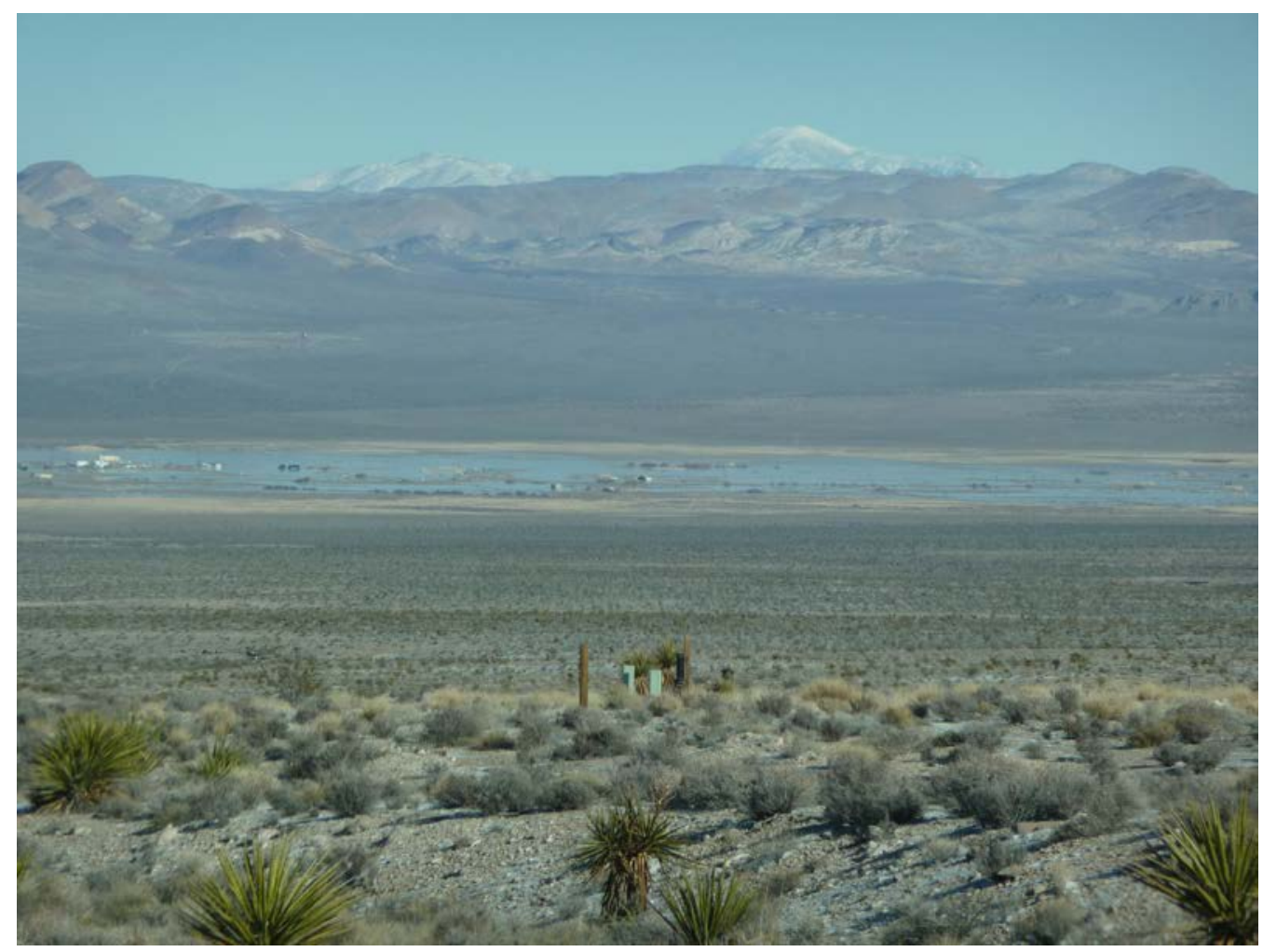

Figure 15. Inundation of Frenchman Flat playa on January 5, 2011. 


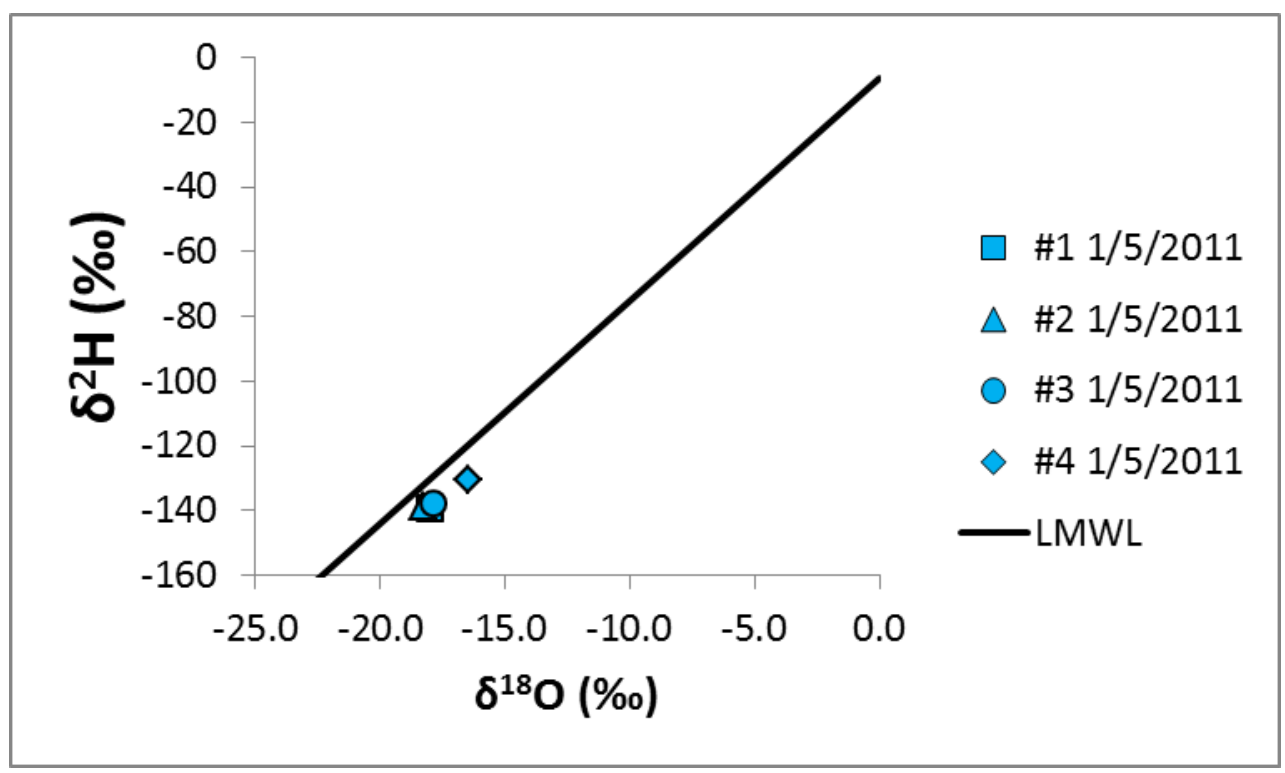

Figure 16. Homogenous isotopic signature of water samples from Frenchman Flat playa shortly after the maximum extent of inundation in the winter of 2010-2011. Water samples plot close to the local meteoric water line (LMWL; $\delta^{2} \mathrm{H}=6.87 \delta^{18} \mathrm{O}-6.5$; Ingraham et al., 1991).

For example, samples were collected from location \#1 for the three different sampling events in 2011 because water was present at this location each time. However, these samples showed little, if any, evaporation from this deep, narrow pool of water (Figure 17, 18, and 19) even though the depth of water had decreased by roughly $1 \mathrm{~m}$ or more. Because these samples did not show any evaporation, they can be used to represent the average isotopic signature of the precipitation that inundated the playa during the winter of 2010-2011. However, at location \#4, the isotopic signature changed as water at this location evaporated from January 5, 2011 to January 26, 2011 (Figure 20 and 21). An evaporation line can be drawn between these two points (Figure 22). If all of the water samples are plotted (Figure 23), the water samples from the winter of 2010-2011 all plot along this evaporation line showing these samples all originated from the same precipitation event that caused the inundation. The water samples from March 9, 2010 do not fall on this evaporation line indicating that the average isotopic signature of precipitation that caused the inundation in the winter of 2009-2010 was different from the winter of 2010-2011. 


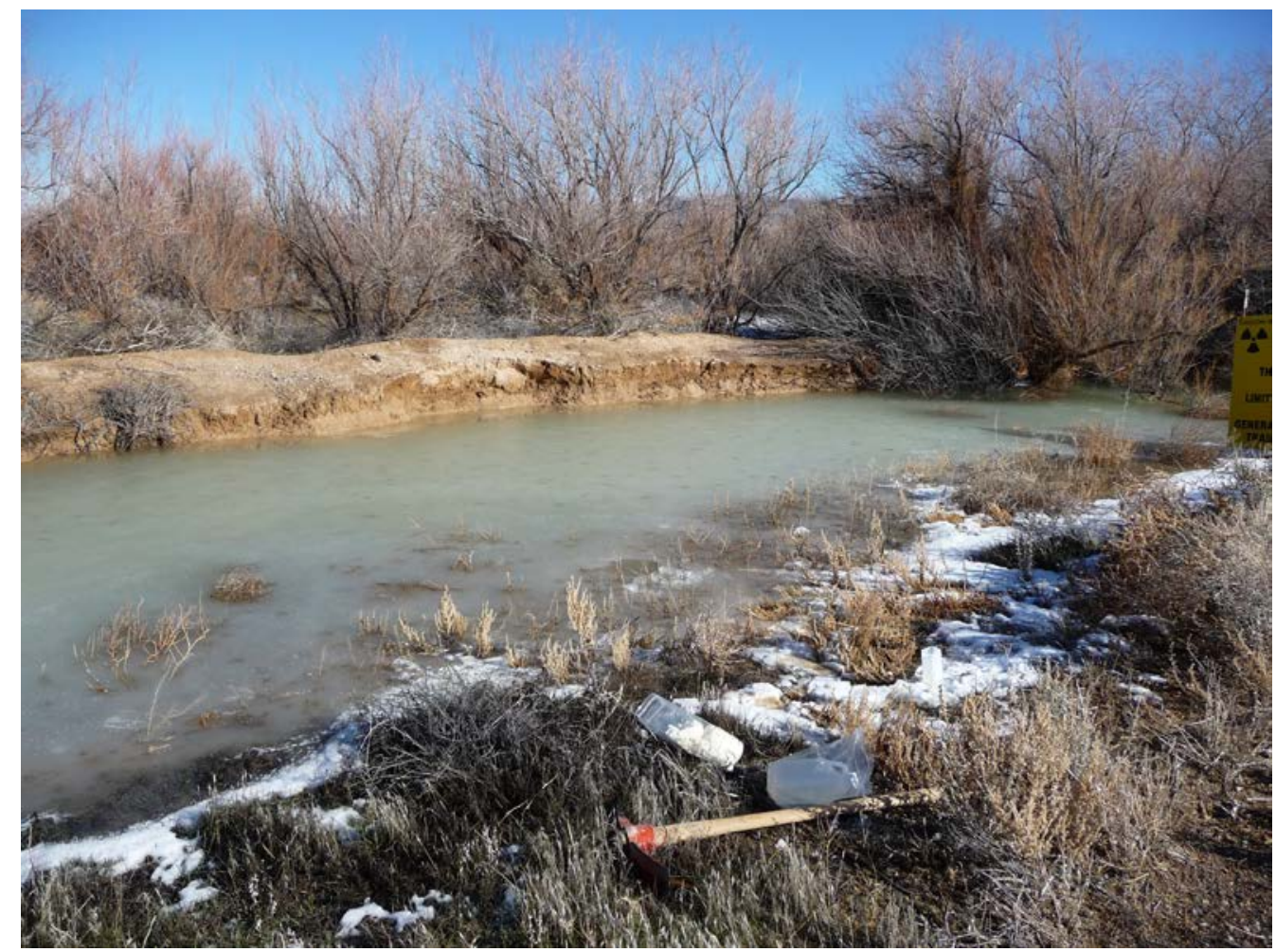

Figure 17. Sampling location \#1, January 5, 2011.

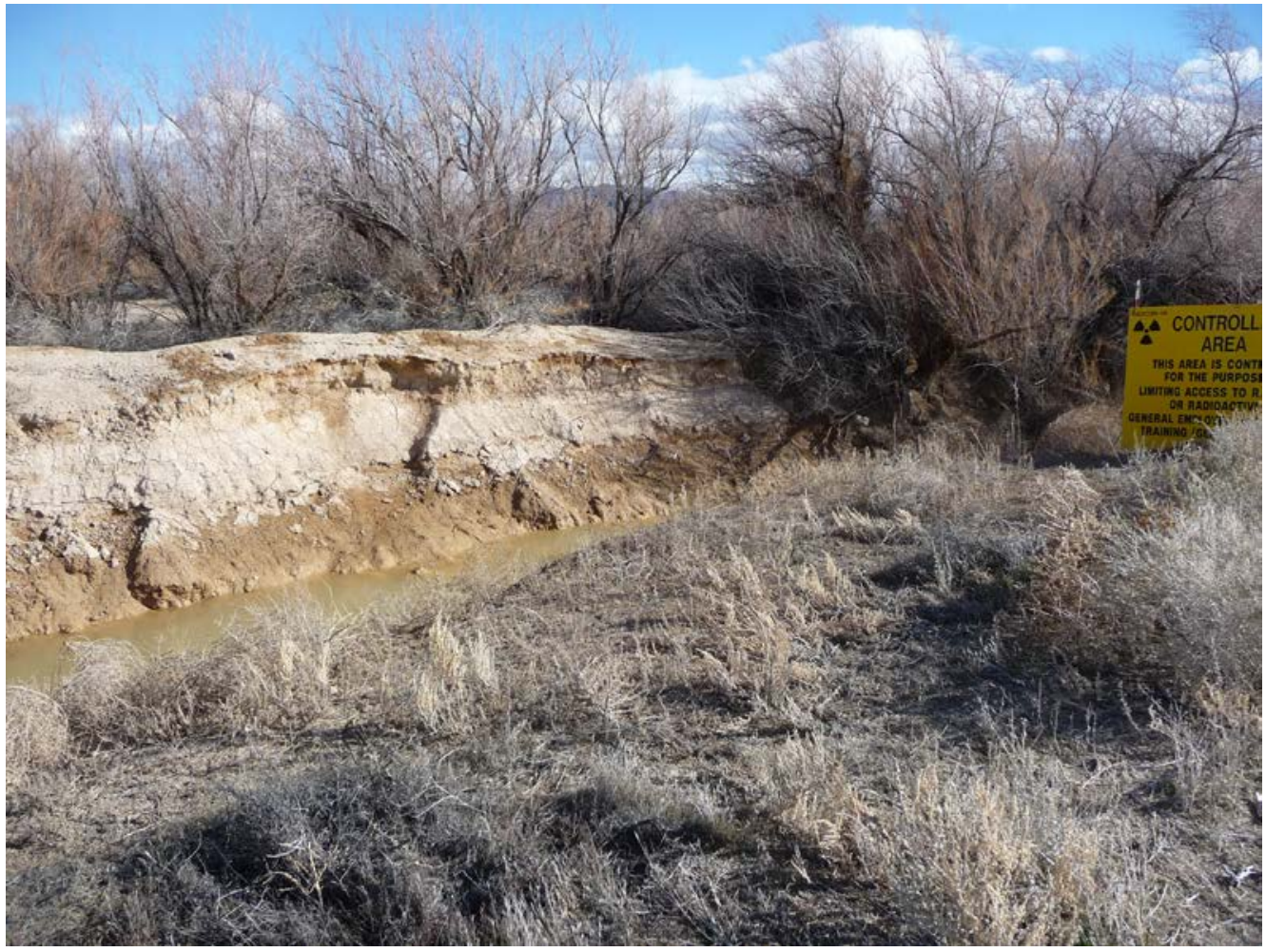

Figure 18. Sampling location \#1 on February 16, 2011. 


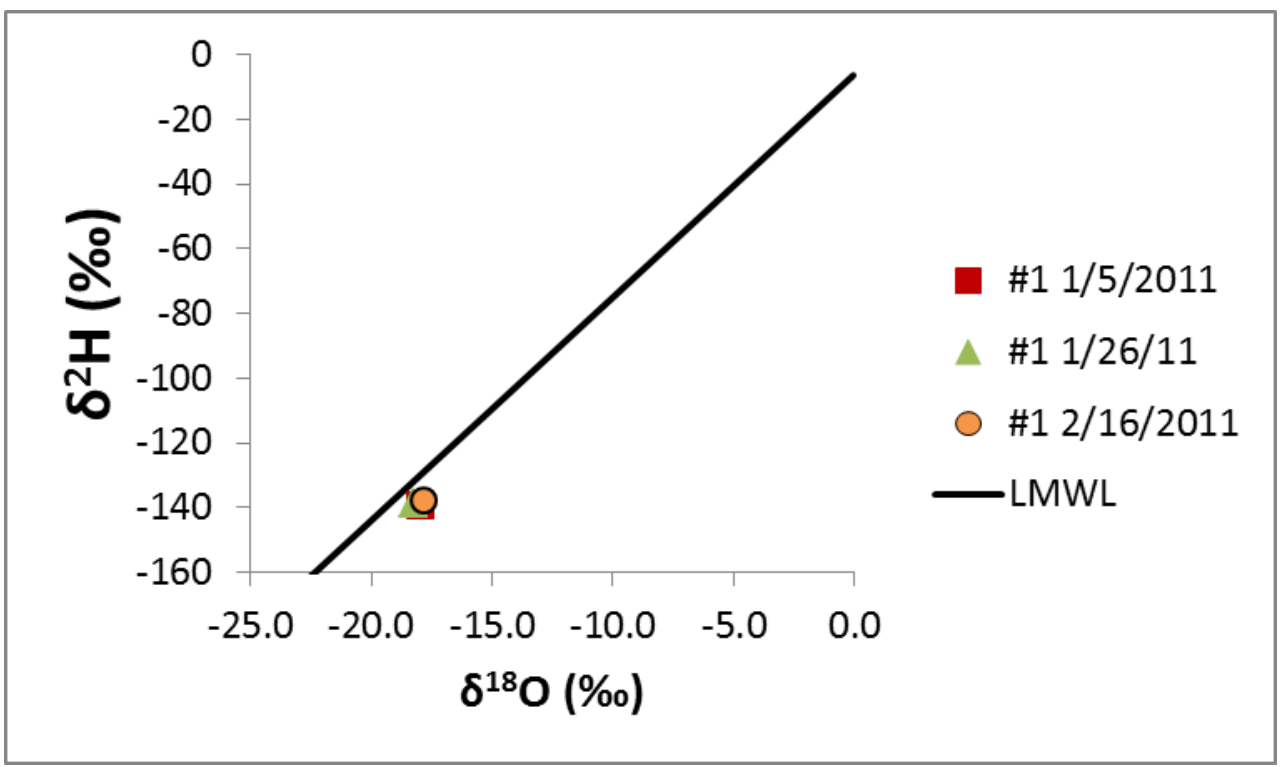

Figure 19. No change in isotopic signature (no evaporation) from sample location \#1 as water on Frenchman Flat playa receded. The local meteoric water line is shown for reference (LMWL; $\delta^{2} \mathrm{H}=6.87 \delta^{18} \mathrm{O}-6.5$; Ingraham et al., 1991).

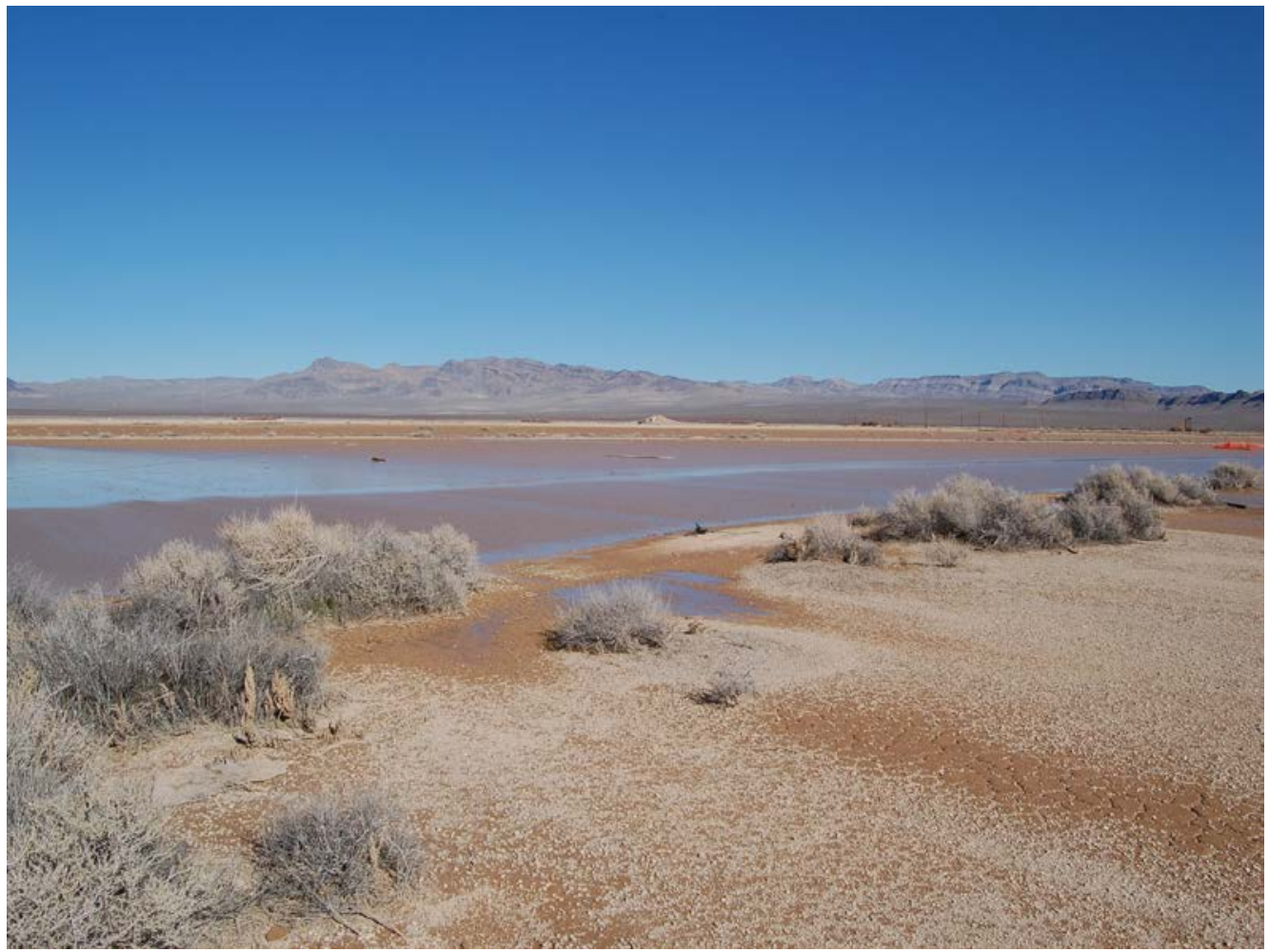

Figure 20. Sample location \#4 on January 26, 2011. 


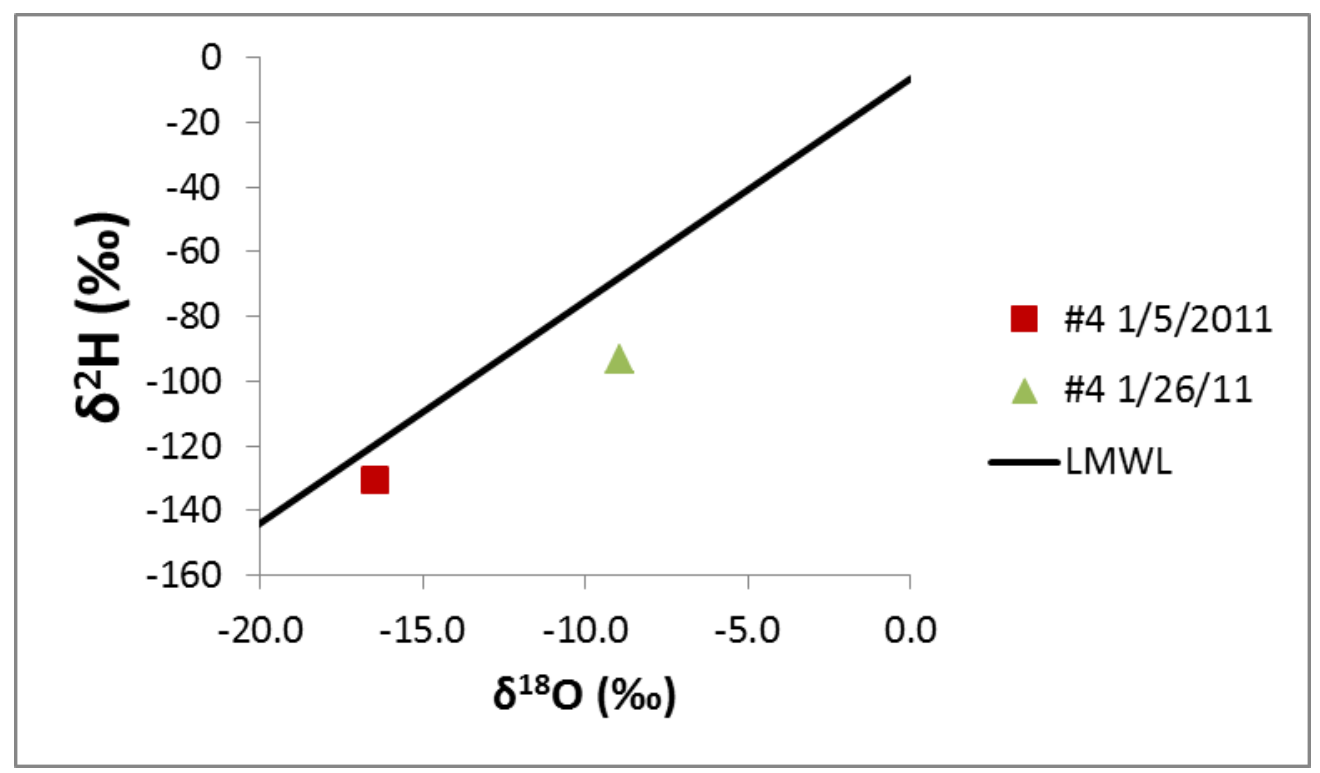

Figure 21. Change in isotopic signature showing evaporation at sample location \#4 from, January 5, 2011 to January 26, 2011. The local meteoric water line is shown for reference (LMWL; $\delta^{2} \mathrm{H}=6.87 \delta^{18} \mathrm{O}-6.5$; Ingraham et al., 1991).

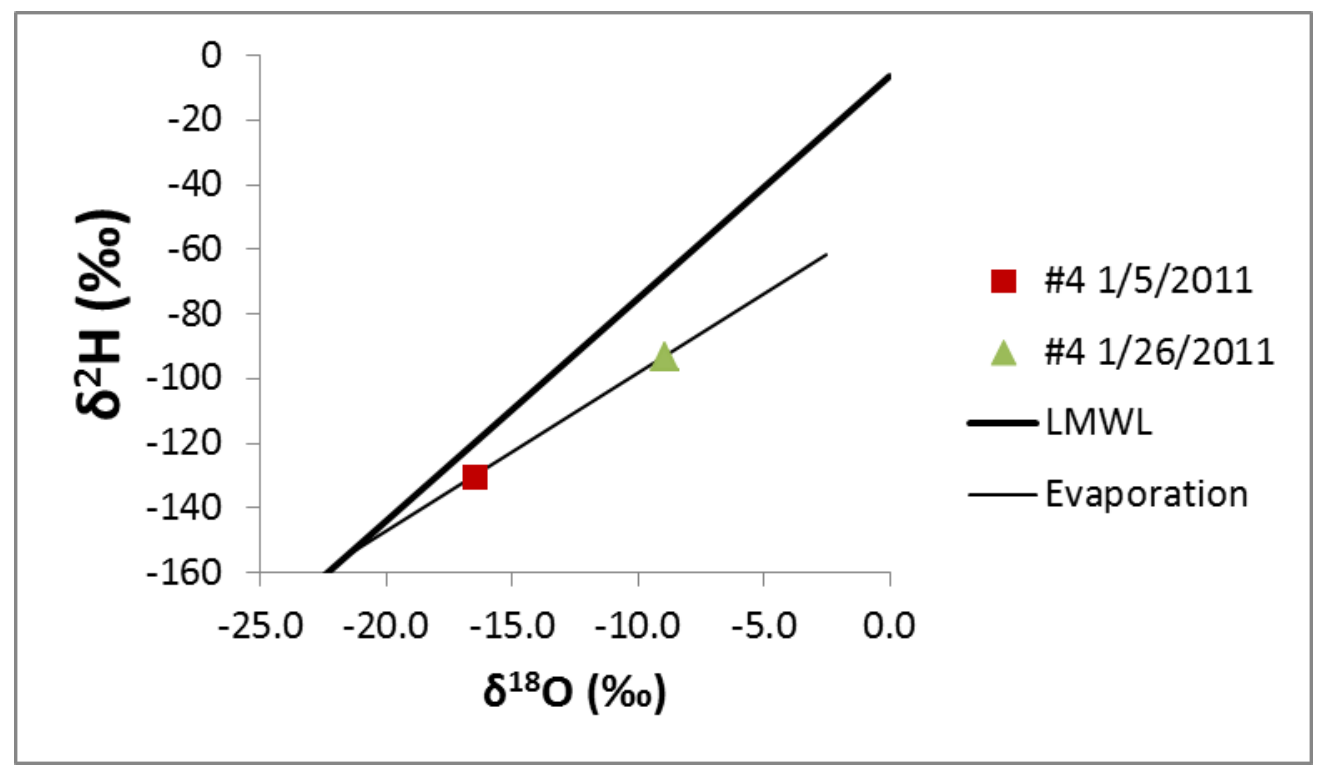

Figure 22. Evaporation line for sample location \#4 from January 5, 2011 to January 26, 2011. The local meteoric water line is shown for reference (LMWL; $\delta^{2} \mathrm{H}=6.87 \delta^{18} \mathrm{O}-6.5$; Ingraham et al., 1991) 


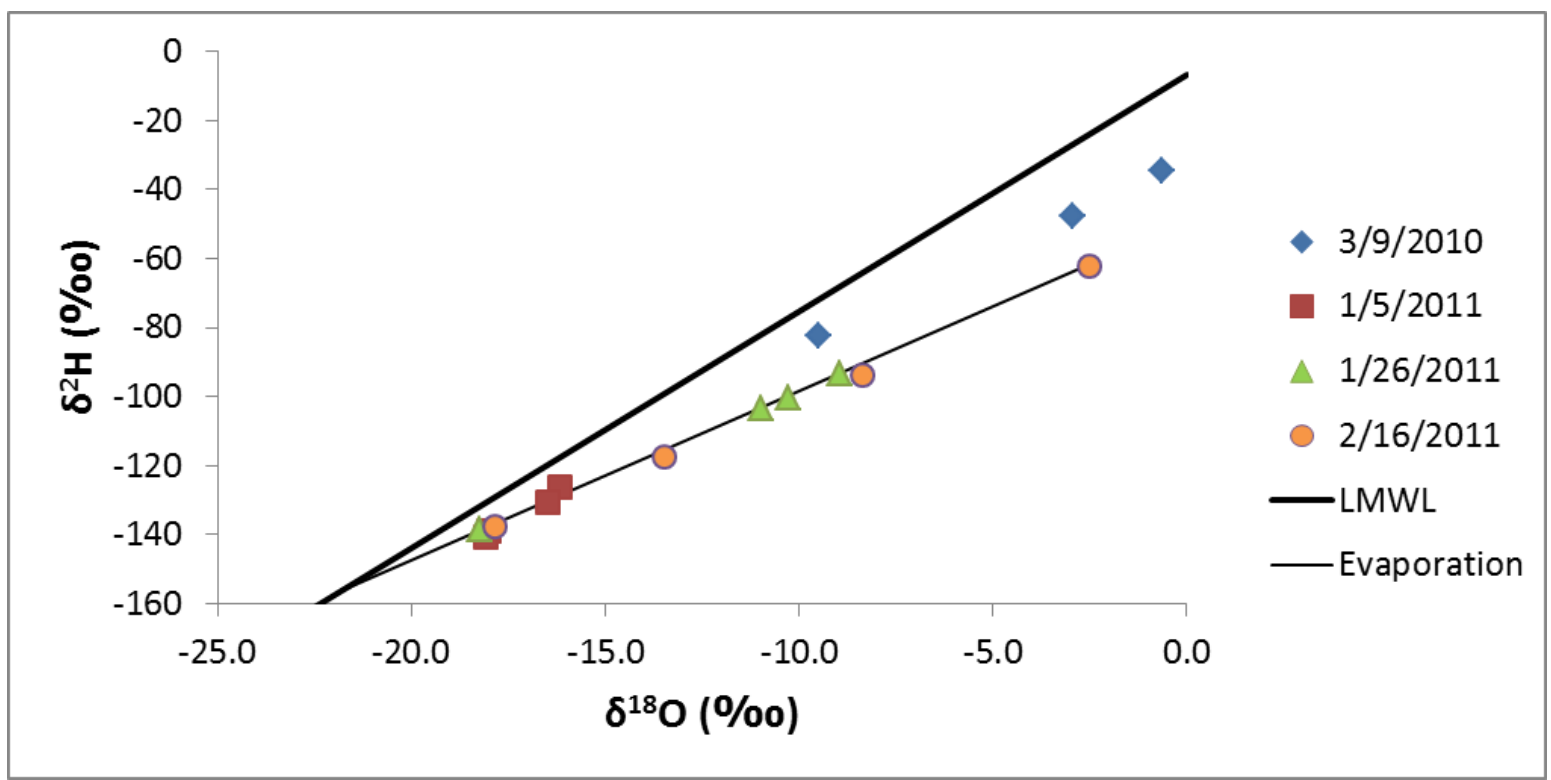

Figure 23. The isotopic signatures of water samples from the winter of 2010-2011 plot along the evaporation line for sample location \#4 from January 5, 2011 to January 26, 2011. The isotopic signatures of water samples from the winter of 2009-2010 plot off of this line.

The amount of evaporation from the playa can be estimated using $\delta^{2} \mathrm{H}$ and $\delta^{18} \mathrm{O}$ values and the Rayleigh distillation equation (Fritz and Clark, 1997). For the winter of 20102011, the isotopic signatures from February 16, 2011, when the water on the playa was mostly gone, were used along with the isotopic signature from location \#1 January 5, 2011 since location \#1 was not evaporated. Also needed for this calculation is the average relative humidity and temperature between initial January 5 and February 16, 2011. (W5b; http://www.sord.nv.doe.gov/home_climate_rain.htm). Using these data, the amount of evaporation from playa inundation during the winter of 2010-2011 ranged from 1 to 57 percent depending on sample location (Table 11). These estimated amounts of evaporation correspond to 98 percent of the playa inundation surface area having receded.

Table 11. Estimates of evaporation from Frenchman Flat playa during inundation from January 5, 2011 to February 16, 2011.

\begin{tabular}{lccccc}
\hline $\begin{array}{l}\text { Sample } \\
\text { Location } \\
\text { Number }\end{array}$ & $\begin{array}{c}\text { Average } \\
\text { Temperature } \\
\left({ }^{\circ} \mathbf{C}\right)\end{array}$ & $\begin{array}{c}\text { Average } \\
\text { Relative } \\
\text { Humidity } \\
\mathbf{( \% )}\end{array}$ & $\begin{array}{c}\text { Water } \\
\text { Evaporated } \\
\mathbf{\delta}^{\mathbf{1 8}} \mathbf{O} \\
\mathbf{( \% )}\end{array}$ & $\begin{array}{c}\text { Water } \\
\text { Evaporated } \\
\mathbf{\delta}^{\mathbf{2}} \mathbf{H} \\
\mathbf{( \% )}\end{array}$ & $\begin{array}{c}\text { Average } \\
\text { Water } \\
\text { Evaporated } \\
\mathbf{( \% )}\end{array}$ \\
\hline$\# 1$ & 3.2 & 55.0 & 0.8 & 1.3 & 1.1 \\
$\# 2$ & 3.2 & 55.0 & 22.6 & 18.2 & 20.4 \\
$\# 3$ & 3.2 & 55.0 & 42.0 & 34.2 & 38.1 \\
$\# 4$ & 3.2 & 55.0 & 58.3 & 51.1 & 57.4 \\
\hline
\end{tabular}


Table 12. Particle size analysis and textural classification for two archived Frenchman Flat playa soil samples.

\begin{tabular}{lcccccc}
\hline & $\begin{array}{c}\text { Gravel } \\
(\%)\end{array}$ & $\begin{array}{c}<\mathbf{2 ~ m m} \\
\text { Sand } \\
\mathbf{( \% )}\end{array}$ & $\begin{array}{c}\text { Silt } \\
\mathbf{( \% )}\end{array}$ & $\begin{array}{c}\text { Clay } \\
\mathbf{( \% )}\end{array}$ & $\mathbf{\%}$ & $\begin{array}{c}\text { Texture } \\
\text { Classification }\end{array}$ \\
\hline$\# 1: 5-15 \mathrm{~cm}$ & 2.3 & 38.2 & 52.5 & 9.3 & 100.0 & Silt Loam \\
$\# 1: 15-30 \mathrm{~cm}$ & 5.8 & 58.5 & 33.8 & 7.7 & 100.0 & Sandy Loam \\
$\# 1: 30-60 \mathrm{~cm}$ & 2.2 & 59.0 & 32.8 & 8.2 & 100.0 & Sandy Loam \\
$\# 2: 5-15 \mathrm{~cm}$ & 0.0 & 9.9 & 75.4 & 14.8 & 100.0 & Silt Loam \\
$\# 2: 15-30 \mathrm{~cm}$ & 0.0 & 13.2 & 72.8 & 14.0 & 100.0 & Silt Loam \\
$\# 2: 30-60 \mathrm{~cm}$ & 0.0 & 20.3 & 63.6 & 16.1 & 100.0 & Silt Loam \\
\hline
\end{tabular}

Considering the low TDS of the water samples from the two inundations in the winters of 2009-2010 and 2010-2011 and the maximum estimated evaporation of 57 percent from stable isotopes that correspond with the disappearance of most of the water, a significant proportion of water from these two inundations (43 percent) appears not to have evaporated, but rather may have infiltrated into the subsurface. The best example of this occurred at sample location \#1 where there was no significant evaporation, but the depth of water decreased by $1 \mathrm{~m}$ or more (Figures 17 and 18). Note that infiltration does not imply groundwater recharge as the depth to groundwater in Frenchman Flat is at least $208 \mathrm{~m}$ from the playa surface (Bright et. al., 2001). Using stable isotopes and other water infiltration tracers in soil profiles, Tyler et al. (1996) concluded that groundwater recharge is not occurring in Frenchman Flat near the Area 5 Radioactive Waste Management Site under current climatic conditions and that the last time groundwater recharged occurred was possibly 20,000 years ago.

Other supporting evidence that some infiltration is occurring is the particle size analysis from the two archived Frenchman Flat playa soil samples. The particle size analysis of these two soil samples shows that the clay content of the near-surface soil is low (Table 12); the corresponding saturated hydraulic conductivity for a typical sandy loam $\left(1.2 \times 10^{-3} \mathrm{~cm} / \mathrm{s}\right.$; Šimůnek et al., 1998) is relatively high suggesting infiltration (to an unknown depth) is possible in some areas of the Frenchman Flat playa. The saturated hydraulic conductivity for a typical silt loam is an order of magnitude lower (1.25 x 10 $10^{-4} \mathrm{~cm} / \mathrm{s}$; Šimůnek et al., 1998).

\section{Radionuclide Analysis of Playa Water}

Playa water samples analyzed by the University of Nevada, Las Vegas Radioanalytical Service Laboratory for gamma spectroscopy did not show any man-made radioactivity. Four samples had measureable activity of naturally occurring potassium-40 (27-51 pCi/L); one sample had measurable activity of protactinium-234m (490 pCi/L).

Because no man-made radioactivity was measured with gamma spectroscopy, samples were not analyzed for alpha or beta activity. Although no device-related radioactivity was detected in water samples from the inundated playa analyzed by gamma spectroscopy, the short length of scanning time (24 hours) and the relative chemical diluteness of the water samples (TDS ranged between 39 and $190 \mathrm{mg} / \mathrm{L}$ ) may have contributed to none being detected. Additionally, any low-energy beta emitting radionuclides would not have been detected by gamma spectroscopy. 


\section{X-Ray Diffraction Results}

Residual sediment that settled to the bottom of the sample bottles prior to filtering, along with any flocculated colloidal material and precipitated minerals that accumulated after filtering were retained for mineral identification by XRD. Minerals identified by XRD are shown in Table 13. Results show that all samples have similar mineralogy including calcite, quartz, and sheet silicate/clays at slightly different ratios. All samples probably also contain some plagioclase (using the reference patterns for albite and microcline). The clay component of the samples is likely kaolinite, and a mica mineral, possibly muscovite or illite. Montmorillonite and palygorskite (Mg, Al, Si clay) also may be present. Gypsum and potassian halite may be present in one or two samples.

Because soil sampling was not within the scope of this study, two archived Frenchman Flat playa soil samples were analyzed by XRD; results for bulk soil samples are shown in Table 14. All samples showed very similar XRD scans; the minerals identified were plagioclase (anorthite), quartz, K-feldspar (orthoclase), illite, calcite, and clinoptilolite (heulandite). Two samples, \#1: 5-15 cm and \#2: 5-15 cm, were wet sieved (65 $\mu \mathrm{m}$, distilled water) and analyzed by XRD for the clay mineral size fraction; results are shown in Table 15. The major clay minerals identified in the clay-size fraction were smectite and illite; the minor minerals were quartz, clinoptilolite (heulandite); and the minerals in trace amounts were vermiculite and kaolinite. Although smectite is a major mineral in the XRD analysis of the clay-size fraction, the clay-size fraction of the soil samples is very small, on average, roughly 10-12 percent (Table 12). Minerals that are present at less than 5 percent (i.e. smectite in the bulk analysis) are not always detected by XRD. 
Table 13. Minerals identified by XRD in residual sediment, flocculated colloidal material, and precipitated materials from Frenchman Flat playa water samples.

\begin{tabular}{|c|c|c|c|c|c|c|c|c|c|}
\hline Sample Name & Minera & & & & & & & & \\
\hline 3/9/2010 \#1 & calcite & kaolinite & quartz & albite & microcline & palygorskite & montmorillonite & muscovite & \\
\hline 3/9/2010 \#2 & no samp & & & & & & & & \\
\hline 3/9/2010 \#3 & calcite & kaolinite & quartz & albite & microcline & palygorskite & montmorillonite & muscovite & \\
\hline 1/5/2011 \#1 & calcite & kaolinite & quartz & albite & & & & muscovite & potassian halite \\
\hline 1/5/2011 \#2 & calcite & kaolinite & quartz & albite & & palygorskite & montmorillonite & muscovite & \\
\hline 1/5/2011 \#3 & calcite & kaolinite & quartz & albite & & palygorskite & montmorillonite & muscovite & \\
\hline 1/5/2011 \#4 & calcite & kaolinite & quartz & albite & & palygorskite & montmorillonite & muscovite & \\
\hline 1/26/2011 \#1 & calcite & kaolinite & quartz & albite & & palygorskite & montmorillonite & muscovite & \\
\hline 1/26/2011 \#2 & calcite & kaolinite & quartz & albite & & palygorskite & montmorillonite & muscovite & \\
\hline 1/26/2011 \#3 & calcite & kaolinite & quartz & albite & microcline & palygorskite & montmorillonite & muscovite & \\
\hline 1/26/2011 \#4 & calcite & kaolinite & quartz & albite & & palygorskite & montmorillonite & muscovite & \\
\hline 2/16/2011 \#1 & no samp & & & & & & & & \\
\hline 2/16/2011 \#2 & calcite & kaolinite & quartz & albite & microcline & palygorskite & montmorillonite & muscovite & \\
\hline 2/16/2011 \#3 & calcite & kaolinite & quartz & albite & microcline & palygorskite & montmorillonite & muscovite & \\
\hline 2/16/2011 \#4 & calcite & kaolinite & quartz & albite & & palygorskite & montmorillonite & muscovite & \\
\hline
\end{tabular}


Table 14. Semi-quantitative XRD results for two archived Frenchman Flat soil samples from three different depths.

\begin{tabular}{|c|c|c|c|c|c|c|}
\hline Soil Sample & $\begin{array}{c}\# 1: \\
5-15 \mathrm{~cm}\end{array}$ & $\begin{array}{c}\# 1: \\
15-30 \mathrm{~cm}\end{array}$ & $\begin{array}{c}\# 1: \\
30-60 \mathrm{~cm}\end{array}$ & $\begin{array}{c}\# 2: \\
5-15 \mathrm{~cm}\end{array}$ & $\begin{array}{c}\# 2: \\
15-30 \mathrm{~cm}\end{array}$ & $\begin{array}{c}\# 1: \\
30-60 \mathrm{~cm}\end{array}$ \\
\hline Orthoclase (\%) & 14 & 13 & 12 & 14 & 11 & 11 \\
\hline Quartz (\%) & 22 & 25 & 24 & 19 & 19 & 20 \\
\hline Illite (\%) & 15 & 12 & 12 & 26 & 24 & 23 \\
\hline Calcite (\%) & 7 & 5 & 8 & 16 & 21 & 19 \\
\hline Anorthite (\%) & 37 & 39 & 39 & 22 & 20 & 22 \\
\hline Clinoptilolite (\%) & 6 & 6 & 6 & 4 & 6 & 6 \\
\hline Total (\%) & 100 & 100 & 100 & 100 & 100 & 100 \\
\hline
\end{tabular}

Table 15. Qualitative XRD results for the clay-size fraction for two archived Frenchman Flat soil samples.

\begin{tabular}{lcc}
\hline Soil Sample & $\mathbf{\# 1 :}$ & $\mathbf{\# 2 :}$ \\
& $\mathbf{5 - 1 5} \mathbf{~ c m}$ & $\mathbf{5 - 1 5} \mathbf{~ c m}$ \\
\hline Smectite & Major & Major \\
Illite & Major & Major \\
Vermiculite & Trace & Minor \\
Kaolinite & Trace & Trace \\
Clinoptilolite & Minor & Minor \\
Quartz & Minor & Minor \\
\hline
\end{tabular}

\section{Water-Soil Geochemical Reaction Modeling}

The geochemical software PHREEQC (Parkhurst and Appelo, 1999) was used to model water-soil mineral reactions in the inundated playa to identify and quantify reactions that were consistent with observed changes in water chemistry. The resulting understanding of the water-soil geochemical environment was then used to evaluate the potential aqueous mobility and transport of residual radionuclides from soils by water on the playa. Chemical inputs to model simulations included measured water major-ion chemistry from samples and mineralogy from XRD analysis of soils and sediments.

The technique of inverse modeling was used, which finds sets of minerals and gases that account for changes in the chemical composition of waters from one sampling date to the next. Model simulations were constructed in a series of steps; as the sequence of steps was run, the simulations became progressively more complex as more chemical reactions were incorporated into the model. Modeling simulations included calculation of dissolved species concentrations and mineral saturation indices that describe the state of saturation (undersaturated, saturated, or over-saturated ) of specific minerals that may be present, evaporative concentration (from isotopic estimates) of playa water, interaction of playa water with atmospheric carbon dioxide $\left(\mathrm{CO}_{2}\right)$, and dissolution or precipitation of playa soil minerals.

Initially, analytical results from water samples were entered (Table 14), and the SIs of important water-rock reaction minerals calculated by PHREEQC (Appendix B). This information, along with XRD results, was used to select minerals for the simulations that could be "dissolved" or "precipitated" when reacting with water. 
Next, using PHREEQC, the initial water at a given location and date had an amount of water removed by evaporation as determined from changes in $\delta^{2} \mathrm{H}$ and $\delta^{18} \mathrm{O}$ at the same location at the next sampling date. For example, water with the measured major-ion water chemistry at sample location \#4 on January 5, 2011 had 27 percent of its water removed by evaporation to simulate the observed major-ion chemistry for January 26, 2011. After removing 27 percent of the water by evaporation, the concentration of each dissolved constituent increased only slightly, which produced a poor simulated match to the actual major-ion chemistry on January 26, 2011 (Figure 24). Modeling results for other dates and locations were similar demonstrating that evaporation alone cannot reproduce the observed major-ion concentrations and that dissolution of soil minerals is required to match observed dissolved-ion concentrations.

Given that the water on the playa was in contact with the atmosphere, the partial pressure of $\mathrm{CO}_{2}$ was set for the elevation of Frenchman Flat (log $\left.\mathrm{P}_{\mathrm{CO} 2}=-3.53\right)$ so $\mathrm{CO}_{2}$ can degas or dissolve into the simulated playa water as needed. Also, because the mineral calcite dissolves or precipitates relatively quickly, it tends to stay near saturation under open system conditions (open to the atmosphere), and its SI is partially controlled by $\mathrm{P}_{\mathrm{CO} 2}$. Calcite SI was set to zero (saturation) so that calcite could dissolve or precipitate in the simulated water from the playa as needed. In simulations, the water was first evaporated, which increases the concentration of dissolved constituent's, and then equilibrated with atmospheric $\mathrm{CO}_{2}$ and calcite. As an example, the results of the model simulation for initial water from sample location \#4 on January 5, 2001, to make the final water chemistry at location \#4 for January 26, 2011, is shown in Figure 25. For this initial simulation, the modeled changes in water chemistry by evaporation and equilibration with atmospheric $\mathrm{P}_{\mathrm{CO} 2}$ and calcite still do not adequately capture the actual changes in water chemistry indicating that other water-soil mineral reactions must be added to the simulation. 
(a)

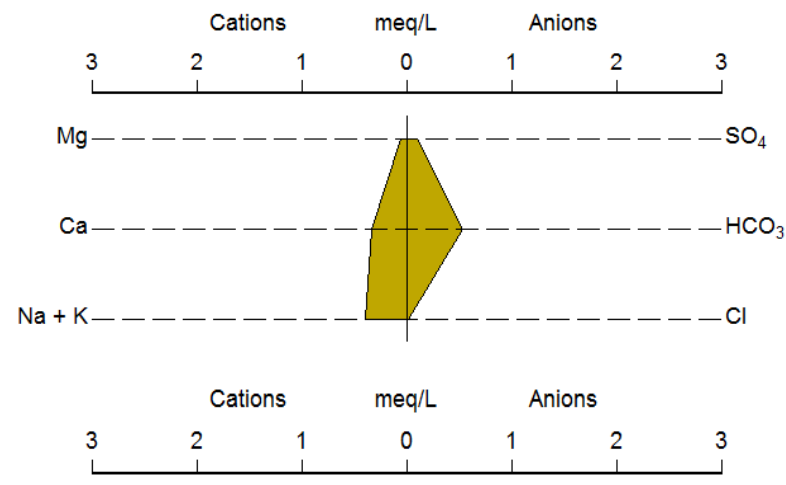

(b)

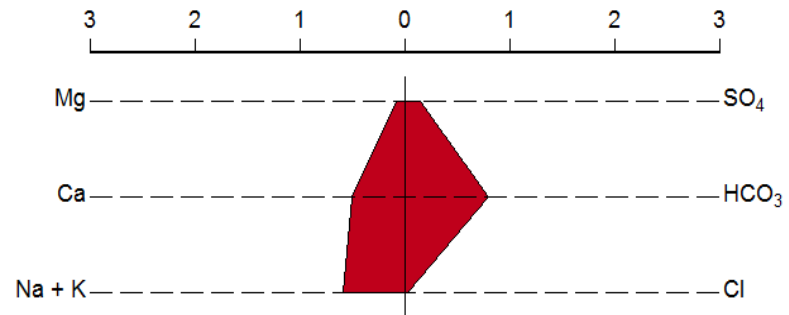

(c)

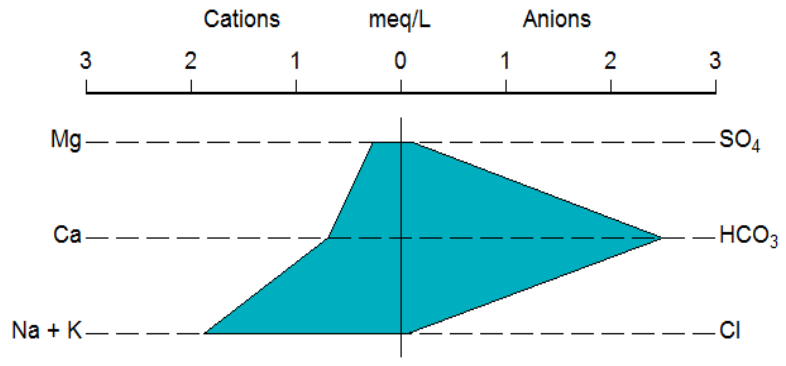

Figure 24. Comparison of PHREEQC modeling simulations to actual water chemistry changes at sample location \#4 from January 5 to January 26, 2011. Only evaporation was modeled. (a) Actual water chemistry on January 5, 2011. (b) PHREEQC modeling simulation from January 5, 2011 to January 26, 2011. (c) Actual water chemistry on January 26, 2011. 
(a)

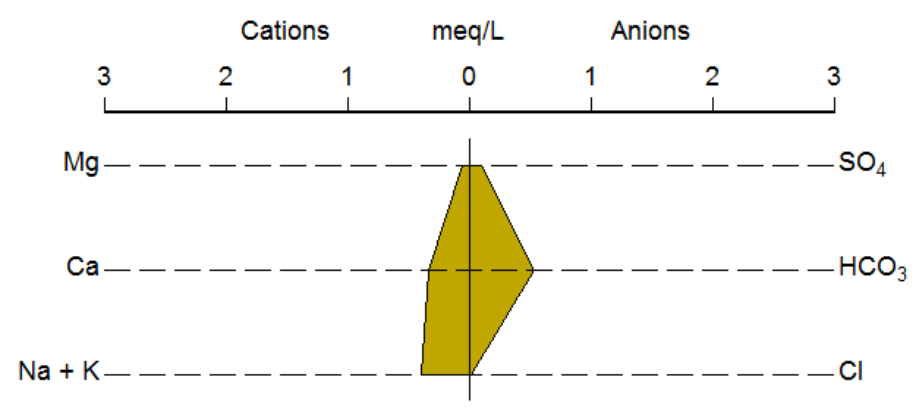

(b)

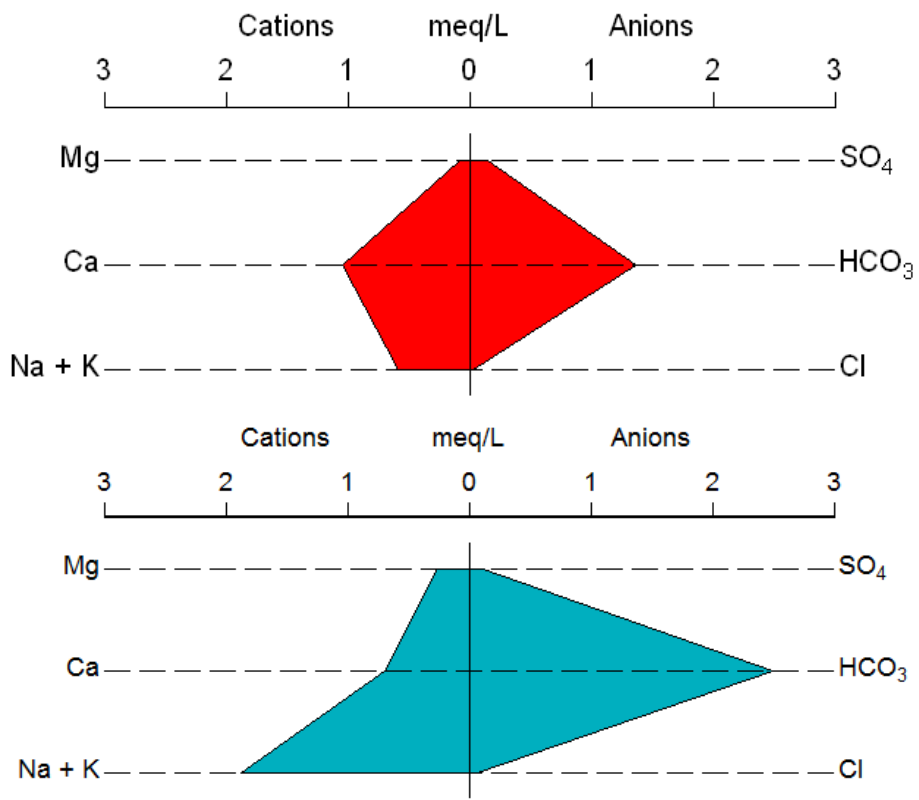

Figure 25. Comparison of PHREEQC modeling simulation to actual water chemistry changes at sample location \#4 from January 5 to January 26, 2011. Simulation included evaporation and equilibrium with atmospheric $\mathrm{P}_{\mathrm{CO} 2}$ and calcite. (a) Actual water chemistry on January 5, 2011. (b) PHREEQC modeling simulation from January 5, 2011 to January 26, 2011. (c) Actual water chemistry on January 26, 2011.

The next series of water-soil mineral reactions to be incorporated in the PHREEQC model simulations included adding dissolution of $\mathrm{NaCl}$ and gypsum. In these simulations, $\mathrm{NaCl}$ is dissolved to add $\mathrm{Na}^{+}$and $\mathrm{Cl}^{-}$to the modeled water and gypsum to add $\mathrm{Ca}^{2+}$ and $\mathrm{SO}_{4}{ }^{2+}$. For these simulations, $\mathrm{NaCl}$ and gypsum were added to match the observed $\mathrm{Cl}^{-}$and $\mathrm{SO}_{4}{ }^{2+}$ in the next water sample. Again, as an example, simulation results for sample location \#4 from January 5, 2011, plus mineral reactions should equal location \#4 from January 26, 2011. Figure 26 illustrates the differences between initial water, simulated final water, and actual final water. Model results have increased concentrations of the major-ions, but have not yet matched the actual major-ion concentrations found in the final water sample. Again, these results indicate that additional water-soil mineral reactions are needed. For example, simulated $\mathrm{Ca}^{2+}$ concentrations are too high suggesting that a mineral sink is needed to remove these excess ions from solution, whereas $\mathrm{Na}^{+}$concentrations are too low suggesting that an additional mineral containing $\mathrm{Na}^{+}$needs to dissolve. 
(a)

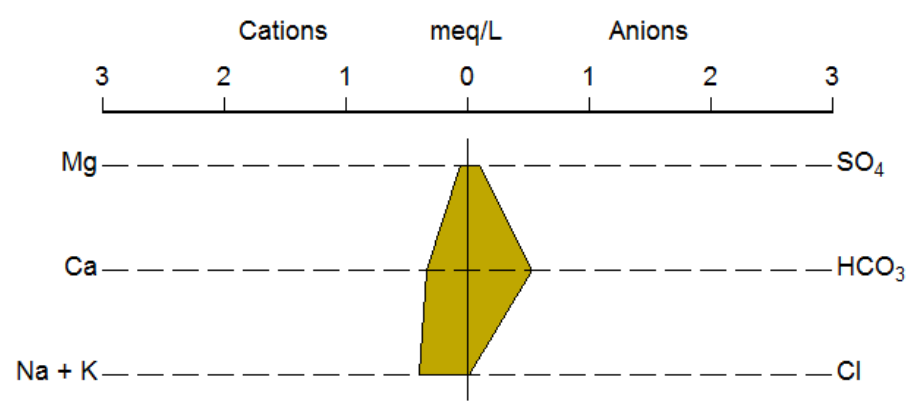

(b)

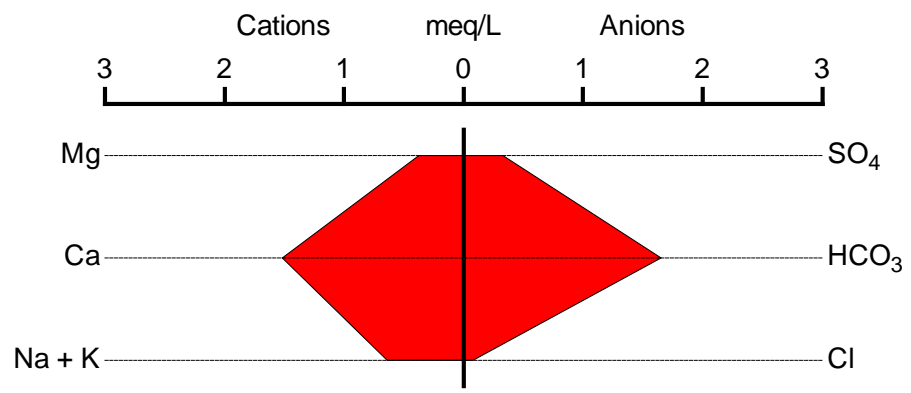

(c)

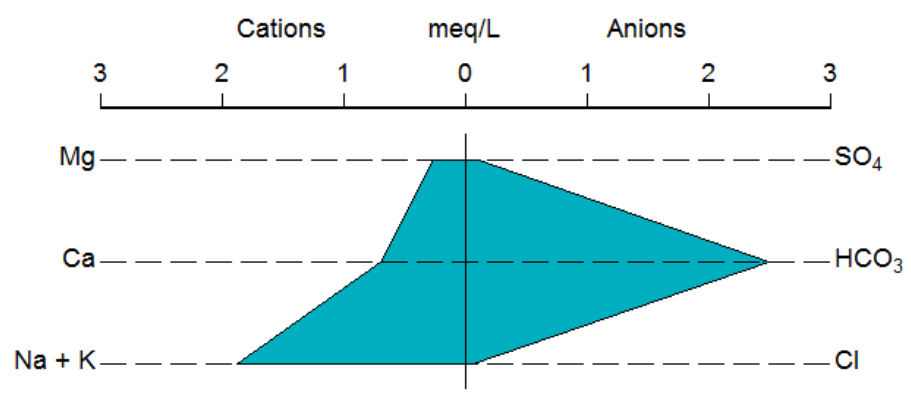

Figure 26. Comparison of PHREEQC model simulation to actual water chemistry changes at sample location \#4 from January 5 to January 26, 2011. Simulation included evaporation, equilibrium with atmospheric $\mathrm{P}_{\mathrm{CO} 2}$ and calcite, and dissolution of $\mathrm{NaCl}$ and gypsum. (a) Actual water chemistry on January 5, 2011. (b) PHREEQC model simulation from January 5, 2011 to January 26, 2011. (c) Actual water chemistry on January 26, 2011.

Additional water-soil mineral reactions incorporated into the PHREEQC model simulations included dissolution of primary volcanic minerals, precipitation of clay minerals, and dissolution or precipitation of quartz. In these simulations, composite chemical formulas were derived from mineralogical characterization of a borehole core from major volcanic aquifers in Pahute Mesa (Benedict et al., 2000; Thomas et al., 2002). The chemical composition of volcanic glass used was $\left(\mathrm{K}_{0.369} \mathrm{Na}_{0.423} \mathrm{Ca}_{0.026} \mathrm{Mg}_{0.003} \mathrm{Fe}_{0.034} \mathrm{Al}_{0.816} \mathrm{Si}_{4.123}\right.$ $\left.\mathrm{O}_{9.946}\right)$, and for clay minerals was $\left(\mathrm{K}_{0.017} \mathrm{Na}_{0.161} \mathrm{Ca}_{0.141} \mathrm{Mg}_{0.138} \mathrm{Fe}_{0.050} \mathrm{Al}_{2.438} \mathrm{Si}_{3.462} \mathrm{O}_{11.024}\right)$. Sufficient composite volcanic glass was dissolved to match $\mathrm{Na}^{+}$concentrations, which often resulted in an excess of $\mathrm{Mg}^{2+}, \mathrm{Ca}^{2+}$, and $\mathrm{K}^{+}$. Sufficient composite clay was then precipitated to remove excess $\mathrm{Mg}^{2+}$ and $\mathrm{K}^{+}$. Excess $\mathrm{Ca}^{2+}$ was removed by equilibrating the simulated solution with atmospheric $\mathrm{CO}_{2}$ and calcite. Excess or insufficient $\mathrm{SiO}_{2}$ was then balanced by precipitating or dissolving quartz. As an example, Figure 27 illustrates the differences between initial water, simulated final water, and actual final water for sample location \#1 
(a)

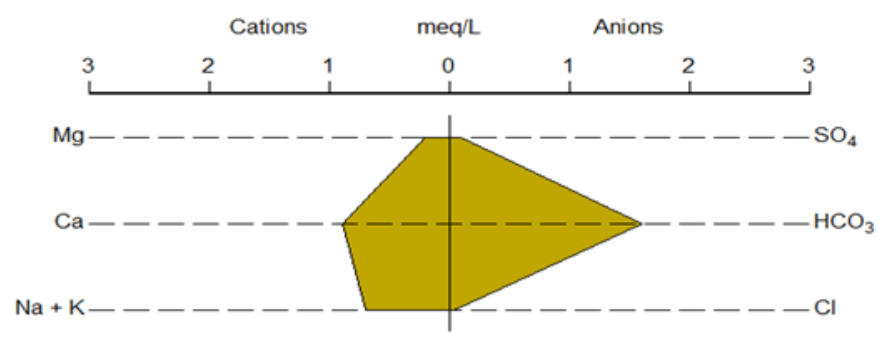

(b)

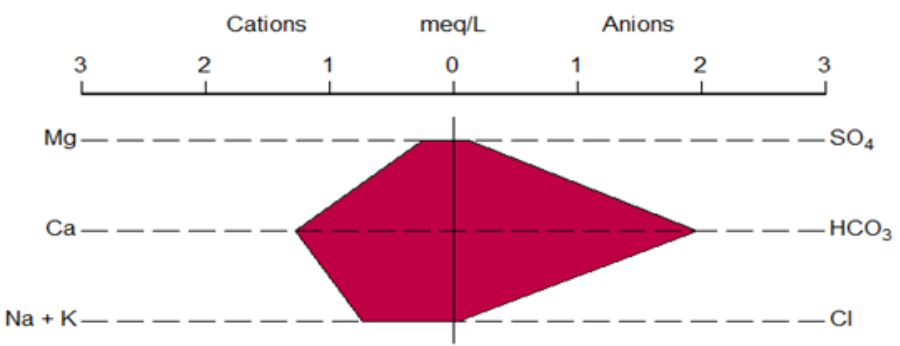

(c)

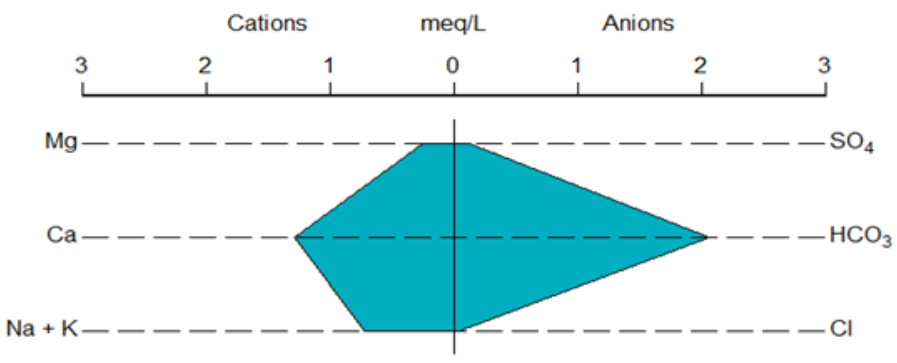

Figure 27. Comparison of PHREEQC model simulation to actual water chemistry changes at sample location \#1 from January 26 to February 16, 2011. Simulation included evaporation; equilibrium with atmospheric $\mathrm{P}_{\mathrm{CO} 2}$ and calcite; dissolution of $\mathrm{NaCl}$, gypsum, and composite volcanic glass; and, precipitation of composite clay and quartz. (a) Actual water chemistry on January 26, 2011; (b) PHREEQC model simulation from January 26, 2011 to February 16, 2011; and (c) actual water chemistry on February 16, 2011.

from January 26, 2011 to February 16, 2011. Model results increased concentrations of the major-ions and most match actual major-ion concentrations.

Water-soil mineral geochemical reaction modeling was generally successful in explaining the changes in chemistry through time as the water disappeared. Relative error was calculated for each simulation by finding the differences between the observed and simulated major-ion concentrations (Table 16). The relative error varied from 0.7 to 9.4 percent with an average relative error of 3.6 percent. Note that any given solution to the mass balance calculations is non-unique, that is, other mineral phases could possibly produce similar results. The water-rock reactions selected are consistent, however, with the observed mineral assemblage for Frenchman Flat playa soils and with geochemical knowledge. 
Table 16. Relative error for water-soil mineral geochemical reaction modeling.

\begin{tabular}{lcccccc}
\hline \multicolumn{1}{c}{ Model Simulation } & $\begin{array}{c}\text { NaCl } \\
\text { (mmol) }\end{array}$ & $\begin{array}{c}\text { Gypsum } \\
\text { (mmol) }\end{array}$ & $\begin{array}{c}\text { Glass } \\
\text { Composite } \\
\text { (mmol) }\end{array}$ & $\begin{array}{c}\text { Clay } \\
\text { Composite } \\
\text { (mmol) }\end{array}$ & $\begin{array}{c}\text { Quartz } \\
\text { (mmol) }\end{array}$ & $\begin{array}{c}\text { Relative } \\
\text { Error }\end{array}$ \\
\hline 1/5/2011 to $1 / 26 / 2011 \# 1$ & 0.017 & 0.030 & 0.255 & -0.045 & -0.889 & 1.09 \\
$1 / 26 / 2011$ to 2/16/2011 \#1 & 0.002 & 0.008 & 0.035 & -0.005 & -0.114 & 0.70 \\
$1 / 5 / 2011$ to $1 / 26 / 2011$ \#4 & 0.036 & -0.018 & 0.600 & -0.100 & -0.002 & 9.39 \\
$1 / 26 / 2011$ \#2 to 2/16/2011 \#3 & 0.030 & 0.010 & 0.485 & -0.080 & -1.730 & 3.58 \\
$1 / 26 / 2011$ \#3 to 2/16/2011 \#4 & 0.010 & 0.054 & 0.030 & -0.002 & -0.170 & 3.22 \\
\hline
\end{tabular}

Negative values $=$ mineral precipitation

Positive values $=$ mineral dissolution

\section{Radionuclide Aqueous Mobility Modeling}

Currently, there is no information on the chemical form of anthropogenic radionuclides in Frenchman Flat playa soils; therefore, it was assumed that soil radionuclides, regardless of chemical form, go into solution when the playa is inundated. Geochemical modeling of radionuclide aqueous mobility was then conducted to evaluate the likelihood of the selected radionuclides sorbing onto soil surfaces (surface complexation) or exchanging with clay surfaces (cation exchange) and being removed from solution (removed from the water on the playa). Several radionuclides were selected for modeling: U, Pu, Cs, and Tc. As described above in the Methods section, Pu and Cs are known to be present at Frenchman Flat playa (DOE, 2010a; DOE, 2010b; IT, 1995; McArthur, 1991; McArthur and Mead, 1989); $\mathrm{U}$ is an important device component with a very long half-life and may be present from aboveground tests (DOE, 2010a); and, Tc is produced from nuclear device testing, has a long half-life, and is very mobile ( $\mathrm{Hu}, 2008)$.

Soil extractions were used to quantify the amount of HFO present in Frenchman Flat playa soil; BET surface area analysis was used to quantify the surface area of the Frenchman Flat playa soils (Table 17); XRD analysis was used to identify and quantify the clay minerals present in Frenchman Flat playa soils (Tables 14 and 15). These data, along with information from Tables 2 and 3, data from Dzombak and Morel (1990), Hinedi et al. (1991), and Zavarin and Bruton (2004b), plus aqueous chemistry data from the inundated playa (Table 9) were used to construct the surface complexation model and cation exchange model frameworks. Model simulations considered a wide range in radionuclide concentrations from 0.1 to 1,000 parts per billion (ppb) ( 0.0001 to $1 \mathrm{mg} / \mathrm{L})$ to identify any effects related to differences in concentration. At greater aqueous concentrations of the sorbate (contaminant or radionuclide), available sorption sites on reactive surfaces can be filled, which then results in greater final aqueous concentrations of the sorbate. This range in concentrations was used only for modeling purposes and does not imply that these concentrations exist in Frenchman Flat playa soils. Aqueous chemistry data from water samples collected in 2010 and 2011 were used as the base water chemistry for all simulations. 
Table 17. Al concentrations from citrate-diothionite extraction; Fe concentrations from hydroxylamine extraction; BET surface area for archived Frenchman Flat soil samples.

\begin{tabular}{lccc}
\hline Soil Sample & Al $\mathbf{( m g} / \mathbf{g})$ & Fe $\mathbf{( m g} / \mathbf{g})$ & Surface Area $\left(\mathbf{m}^{2} / \mathbf{g}\right)$ \\
\hline$\# 1: 5-15 \mathrm{~cm}$ & 0.48 & 0.33 & 38.22 \\
$\# 1: 15-30 \mathrm{~cm}$ & 0.43 & 0.32 & na \\
$\# 1: 30-60 \mathrm{~cm}$ & 0.44 & 0.31 & na \\
$\# 2: 5-15 \mathrm{~cm}$ & 0.61 & 0.47 & 52.01 \\
$\# 2: 15-30 \mathrm{~cm}$ & 0.38 & 0.39 & na \\
$\# 2: 30-60 \mathrm{~cm}$ & 0.45 & 0.41 & na \\
Average & 0.47 & 0.37 & 45.12 \\
\hline na $=$ not analyzed & & &
\end{tabular}

Modeling results for U(VI) sorption onto HFO showed little sorption; less than one percent of the aqueous U(VI) concentration sorbed onto HFO (Figure 28). This finding is consistent with the measured $\mathrm{pH}$ of water on the playa and the presence of carbonate (note, that the presence of $U$ has not actually been observed in Frenchman Flat playa soils). Zavarin and Bruton (2004a) reviewed scientific literature on U(VI) sorption onto HFO and modeled these data with a one-site NEM finding that U(VI) sorbed strongly onto HFO up to $\mathrm{pH}$ 7, but the amount of sorption between $\mathrm{pH} 7$ and $\mathrm{pH} 9$ varied widely (0-100 percent) depending on experimental condition and the type of Fe oxide used. The $\mathrm{pH}$ of the Frenchman Flat playa water samples ranged from 7.9 to 9.0. Wazne et al. (2003) noted that in the presence of carbonate and at higher $\mathrm{pH}, \mathrm{U}(\mathrm{VI})$ sorption onto HFO was greatly reduced. Also, carbonate species have an affinity to sorb onto HFO so there are less sorption sites available for other sorbates (Wazne et al., 2003). All of the results reviewed in Zavarin and Bruton (2004a) were produced in experiments with substantially more HFO (average $5 \times 10^{-4}$ mols of HFO sorption sites) than found in the archived Frenchman Flat soils $\left(0.37 \mathrm{mg} \mathrm{Fe} / \mathrm{g}\right.$ of soil $=8.5 \times 10^{-7} \mathrm{mols}$ of HFO sorption sites; Table 17). The amount of HFO sorption sites available for sorption strongly controls the amount of U(VI) removed from solution. Uranium sorption onto calcite was not modeled since carbonate minerals contribute very little to U(VI) retardation (Zavarin and Bruton, 2004a).

Modeling results for $\mathrm{Pu}(\mathrm{V})$ sorption onto HFO showed more sorption than $\mathrm{U}(\mathrm{VI})$ with the most sorption occurring in the January 5, 2011 samples where $\mathrm{pH}$ was the highest (average $=9.07$ ) and bicarbonate concentrations were the lowest (average $=28.1 \mathrm{mg} / \mathrm{L}$ ) compared to the other sample dates (Figure 29). This sorption behavior is consistent with the summary of the literature by Zavarin and Bruton (2004a), which also noted that other authors observed that $\mathrm{Pu}(\mathrm{V})$ is slowly reduced to $\mathrm{Pu}(\mathrm{IV})$ in experiments in the presence of $\mathrm{HFO}$, and this reaction may be important in Pu transport under atmospheric conditions similar to those on Frenchman Flat. In the surface complexation modeling results here, $\mathrm{Pu}(\mathrm{V})$ sorption decreased as the initial aqueous concentrations increased. This indicates that the sorption sites become filled and cannot sorb any more $\mathrm{Pu}(\mathrm{V})$ at increased aqueous concentrations. The amount of Fe in the archived Frenchman Flat playa soil samples is very low, which results in a limited amount of HFO sorption sites available for $\mathrm{P}(\mathrm{V})$ sorption.

Modeling results for $\mathrm{Pu}(\mathrm{V})$ sorption onto calcite showed more sorption than $\mathrm{P}(\mathrm{V})$ onto HFO, almost 100 percent sorption at lower initial aqueous concentrations of $\mathrm{Pu}(\mathrm{V})$ (Figure 30). Surface complexation modeling results indicate that the sorption sites become 
filled and cannot sorb any more $\mathrm{Pu}(\mathrm{V})$ at increased aqueous concentrations. The number of available sorption sites were based on data from Stipp (1999; surface site density $=8.3 \mathrm{mmol} / \mathrm{m}^{2}$ ), Zavarin et al. (2005; calcite surface area $0.262 \mathrm{~m}^{2} / \mathrm{g}$ ), and the amount of calcite by XRD in the archived Frenchman Flat soil samples (Table 14). The amount of reactive calcite surfaces in Frenchman Flat playa soils was not measured, however, and is highly uncertain. Zavarin et al. (2005) noted that $\mathrm{Pu}(\mathrm{V})$ sorption onto calcite is $\mathrm{pH}$ dependent with the highest sorption occurring between $\mathrm{pH} 8.5$ and 9.5. Surface complexation modeling with Frenchman Flat playa water did not show any variation in sorption because of $\mathrm{pH}$, which ranged from 7.86 to 9.68 (Table 9).

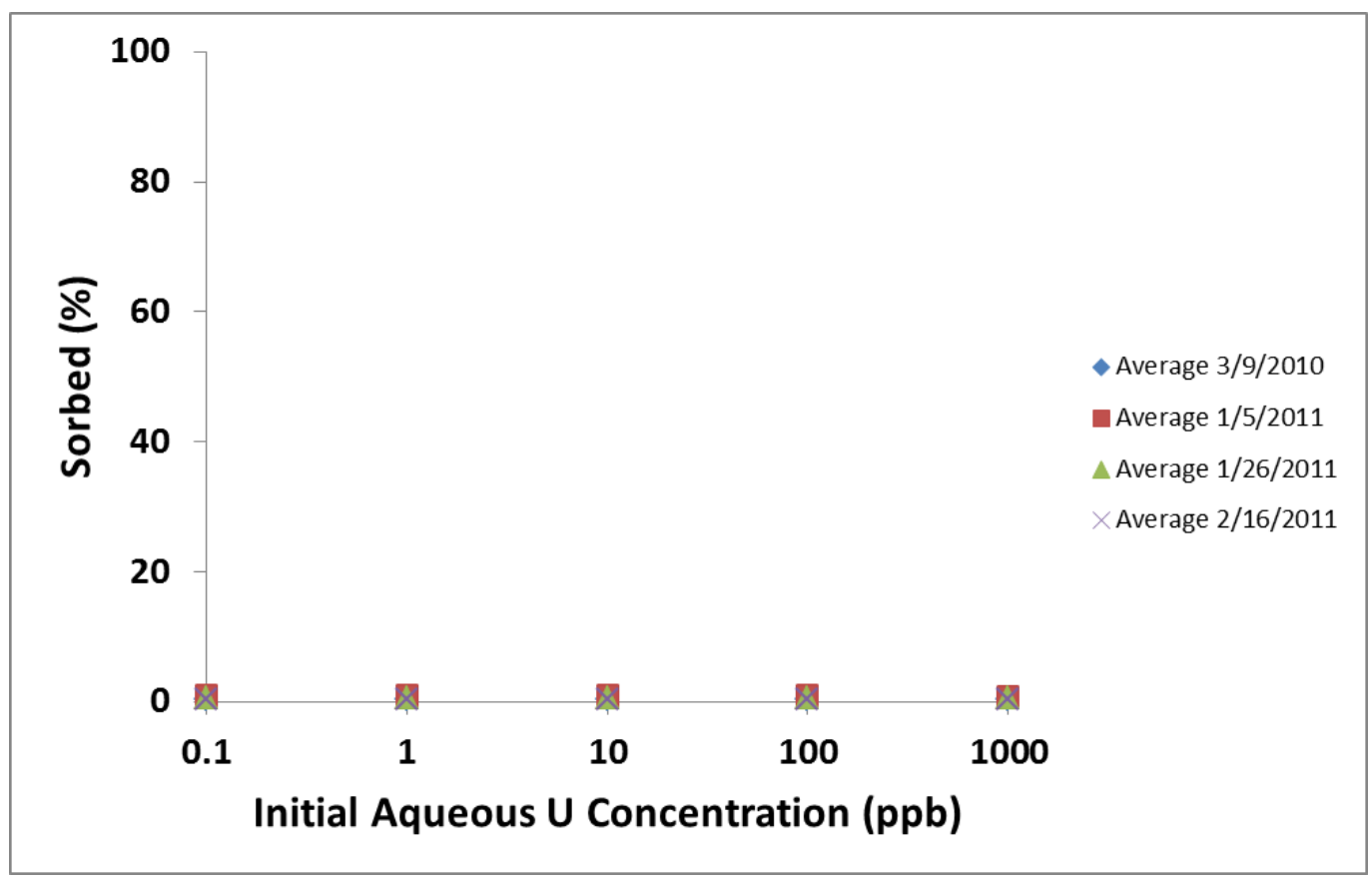

Figure 28. Modeled aqueous U(VI) sorption onto HFO in Frenchman Flat soils. 


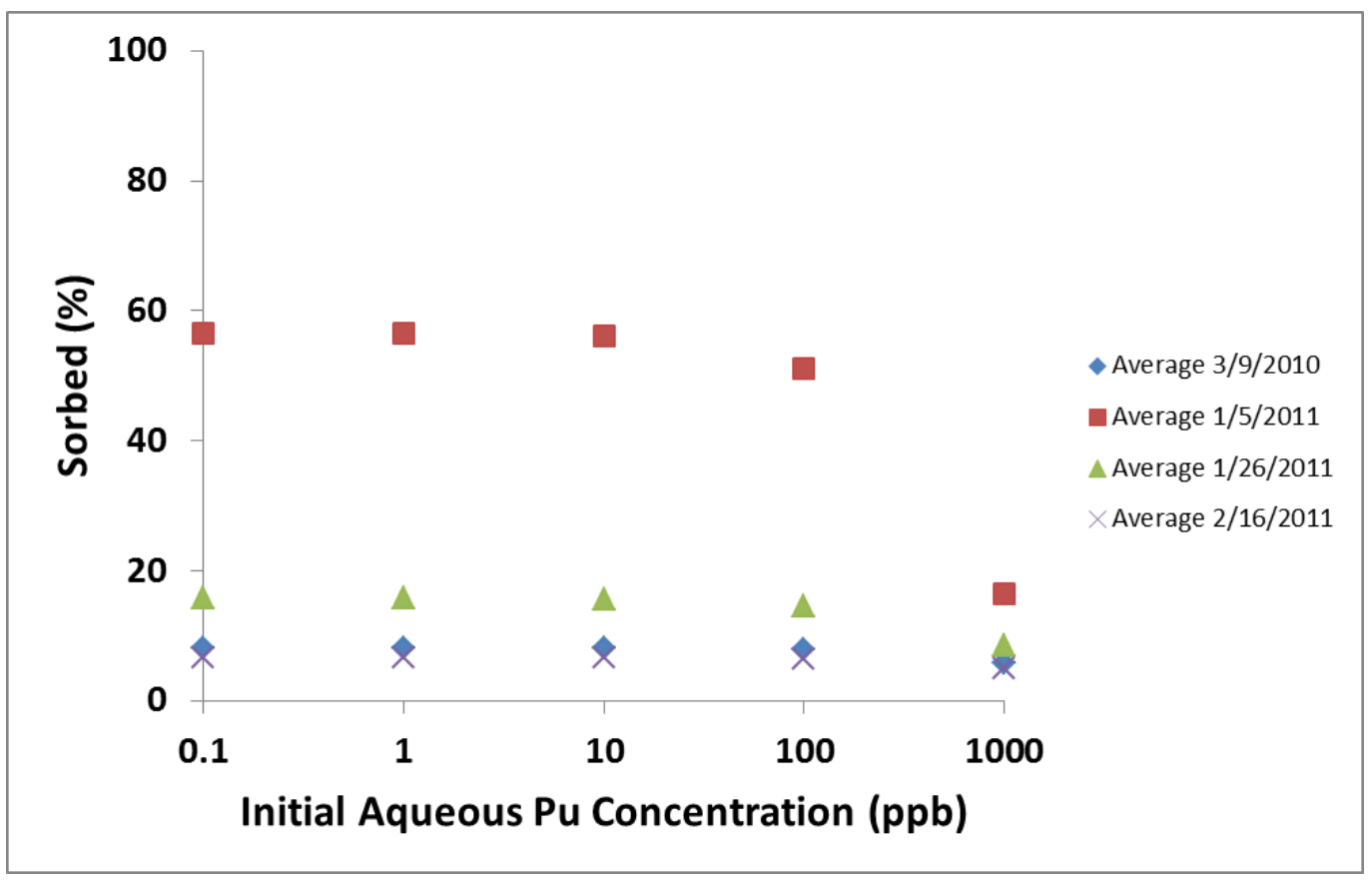

Figure 29. Modeled aqueous $\mathrm{Pu}(\mathrm{V})$ sorption onto HFO in Frenchman Flat soils.

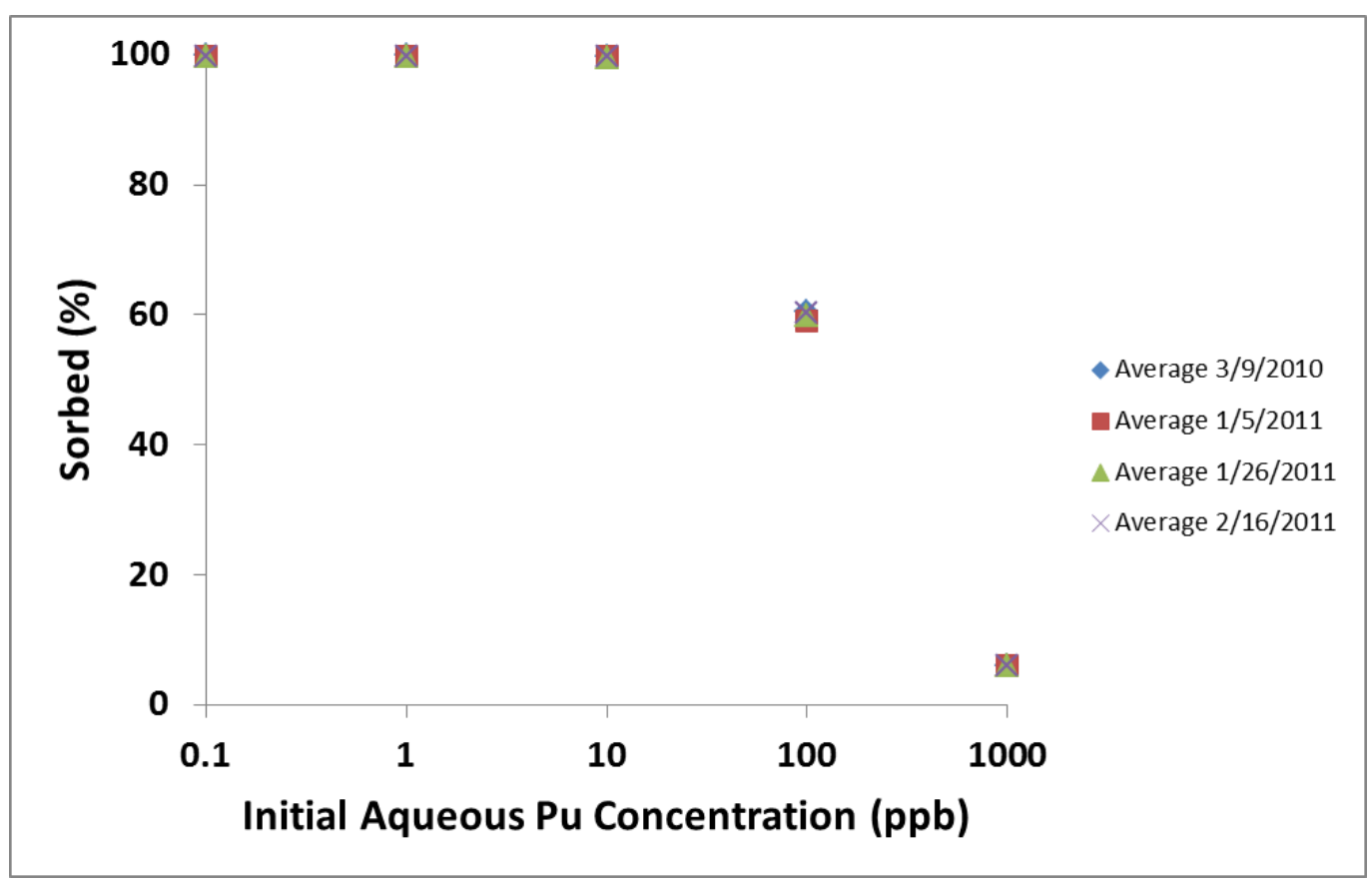

Figure 30. Modeled aqueous $\mathrm{Pu}(\mathrm{V})$ sorption onto calcite in Frenchman Flat soils.

Modeling results for Cs(I) showed little exchange of Cs with clay surfaces (Figure 31), suggesting that Cs in Frenchman Flat playa soils would be very mobile in aqueous form when the playa is inundated. These modeling results are somewhat in contradiction with batch sorption experiments and column flow-through experiments 


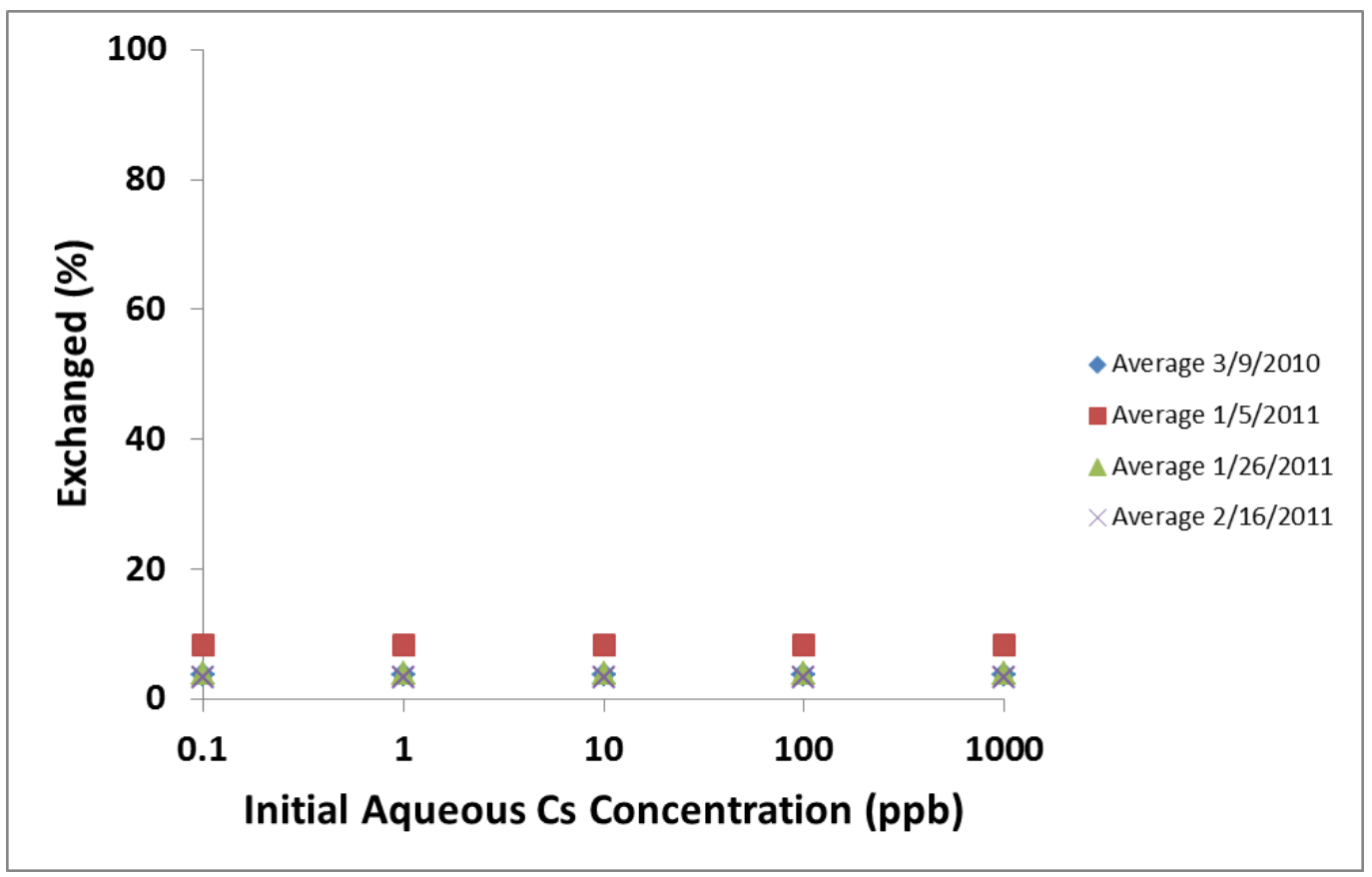

Figure 31. Modeled aqueous Cs(I) exchange onto clays in Frenchman Flat soils.

reported in Zavarin and Bruton (2004b) and Zavarin et al. (2002). In these experiments, sediment samples from deep below the land surface (347.47 and $353.57 \mathrm{~m}$ ) from well UE-5n in Frenchman Flat were used. In batch sorption experiments, Cs concentrations (in mols) decreased by more than two orders of magnitude. In flow-through experiments, Cs was not observed breaking through the end of the columns in any significant quantities. However, the sediments used in these experiments had substantially higher quantities of exchange minerals (by quantitative XRD) than found in the archived Frenchman Flat playa soil samples used in this study. For example, the experimental sediments had more biotite (3 percent), smectite (12-30 percent), and clinoptilolite (1-20 percent) than the playa soil samples (Table 14: biotite [0 percent], smectite [0 percent], clinoptilolite [4-6] percent). Frenchman Flat playa archived soil samples did have illite (Table 14; 12-26 percent), but illite has a much lower CEC $(0.2 \mathrm{meq} / \mathrm{L})$ than smectite $(0.85 \mathrm{meq} / \mathrm{L})$ and clinoptilolite $(2.12 \mathrm{meq} / \mathrm{L})(\mathrm{CEC}$ from Table 7; Zavarin et al., 2002).

Technetium is a redox responsive element and exists in valence states from +7 to -1 , but the most stable oxidation states are +7 and +4 under oxidizing and reducing conditions, respectively ( $\mathrm{Hu}, 2008)$. Under oxidizing conditions, $\mathrm{Tc}(\mathrm{VII})$ exists as the pertechnetate anion $\left(\mathrm{TcO}_{4}{ }^{-}\right)$and is considered one of the most mobile radionuclides in the environment since it has weak interactions with mineral surfaces (Hu, 2008). Because Tc(VII) is considered to be very mobile and surface reactions are not readily available in the scientific literature, Tc(VII) sorption onto mineral surfaces was not modeled.

Radionuclide aqueous mobility modeling suggests that $\mathrm{U}$ and Cs may be soluble in water when Frenchman Flat playa is inundated, and therefore, mobile; Tc is also known to be very mobile in the environment, but has not been observed in Frenchman Flat playa soils. 
Modeling suggests that Pu may be much less mobile in water because of sorption onto calcite, but the amount of reactive surface area of playa soil calcite has not been quantified and is highly uncertain. There is no information on the chemical forms of anthropogenic radionuclides in Frenchman Flat playa soils so it was assumed that soil radionuclides go into solution when the playa is inundated. This may, or may not, be a valid assumption; investigation of the chemical forms of radionuclides in Frenchman Flat playa soils is recommended to address this uncertainty.

\section{CONCLUSIONS}

Geographic information systems, Landsat imagery, and image processing techniques showed that water on Frenchman Flat playa when it was inundated with winter precipitation receded quickly. For example, between January 25, 2011 and February 10, 2011 (16 days), 92 percent of the water on the playa disappeared $\left(2,062,800 \mathrm{~m}^{2}\right)$. Analysis of water chemistry and stable isotopes of water samples from the inundated playa indicated that as much as 60 percent of the water was removed by evaporation while the other 40 percent may have infiltrated into the subsurface. Infiltration into the subsurface does not mean that groundwater recharge is occurring, but infiltration does provide a mechanism to move residual radionuclides in Frenchman Flat playa soils downward into the subsurface. Although no device-related radioactivity was detected in water samples from the inundated playa analyzed by gamma spectroscopy, the short length of scanning time (24 hours) and the relative chemical diluteness of the water samples (TDS ranged between 39 and $190 \mathrm{mg} / \mathrm{L}$ ) may have contributed to none being detected. Additionally, any low-energy beta emitting radionuclides would not have been detected by gamma spectroscopy.

Radionuclide mobility modeling suggested that there would be minimal sorption or exchange of several important radionuclides (U, Cs) with playa minerals such that they may be mobile in water when the playa is inundated and could either infiltrate into the subsurface or be redistributed laterally. Cesium is present in Frenchman Flat playa soils; U may be present because it is a device component, but has not been measured. Mobility modeling also showed that Pu may be much less mobile because of sorption onto calcite, but the amount of reactive surface area of playa soil calcite is highly uncertain. However, $\mathrm{Pu}$ is also known to sorb onto colloidal particles suspended in water and these suspended colloidal particles will move with the water, providing a mechanism to redistribute Pu when Frenchman Flat playa is inundated. Plutonium is present in Frenchman Flat playa soils. Under oxidizing, aqueous conditions, Tc occurs as a negatively charged anion so it is very mobile in the environment and would move with water when Frenchman Flay playa is inundated. Technetium has not been measured in Frenchman Flat playa soils; however, it is a low energy beta emitter so its presence may not have been detected with previous sampling and analysis methods.

\section{RECOMMENDATIONS}

Water chemistry, stable isotopes, and geochemical modeling showed that residual radionuclides in Frenchman Flat playa soils could be mobilized in water when the playa is inundated with winter precipitation. Of particular interest is the potential for infiltration of radionuclides, known to be present on the playa surface, into the subsurface by water.

Recommendations to evaluate aqueous radionuclide movement on Frenchman Flat playa include: 
- Collecting soil samples, both vertically and horizontally, to search for evidence of surface-water infiltration and the presence of radionuclides;

- Examining playa soil samples to identify and characterize the chemical forms of radionuclides residing on the playa surface and those that have migrated downward with infiltrating water;

- Analyzing and characterizing playa soil samples to generate Frenchman Flat playa specific data (soil properties, mineralogy, transport parameters);

- Developing a preliminary unsaturated flow and radionuclide transport model using current data to design a playa soil-sampling plan to guide soil sample collection;

- Refining the preliminary unsaturated flow and radionuclide transport model with this Frenchman Flat playa specific soil data and then;

- Using the refined Frenchman Flat playa specific unsaturated flow and radionuclide transport model to guide discussions on future soil or water sampling, development of remediation strategies, and defining risk-based boundaries for Frenchman Flat playa.

\section{REFERENCES}

Barnes, M.G., J.J. Giacomini, R.T. Reiman, and B. Elliot, 1980. NTS Radiological Assessment Project: Results for Frenchman Lake Region of Area 5. Desert Research Institute, Water Resources Center.

Benedict, C.F., T.P. Rose, and X. Zhou, 2000. Mineralogical, Chemical, and Isotopic Characterization of Fracture-Coating Minerals in Borehole Samples from Western Pahute Mesa and Oasis Valley, Nevada. Lawrence Livermore National Laboratory UCRL-ID152919.

Bowen, S.M., D.L. Finnegan, J.L. Thompson, C.M. Miller, P.L. Baca, L.F. Olivas, C.G. Geoffrion, D.K. Smith, W. Goishi, B.K. Esser, J.W. Meadows, N. Namboodiri, and J.F. Wild, 2001. Nevada Test Site Radionuclide Inventory, 1951-1992. Los Alamos National Laboratory LA-13859-MS.

Craig, H., 1961. Isotopic variations in meteoric waters. Science, 133:1702-1703.

Crist, E.P. and R.C. Cicone, 1984. A physically-based transformation of Thematic Mapper data - The TM Tasseled Cap. IEEE Transactions on Geoscience and Remote Sensing, 22(3):256-263.

Cohen, W. B. and T.A. Spies, 1992. Estimating structural attributes of Douglas-Fir /Western Hemlock forest stands from Landsat and SPOT imagery. Remote Sensing of Environment, 41:1-17.

DOE, 2010a. Corrective Action Investigation Plan for Corrective Action Unit 106: Areas 5, 11 Frenchman Flat Atmospheric Sites Nevada National Security Site, Nevada. U.S. Department of Energy, National Nuclear Security Administration, Nevada Field Office, Las Vegas, Nevada, DOE/NV-1371.

DOE, 2010b. Data Quality Objectives for: CAU 106, Areas 5, 11 Frenchman Flat Atmospheric Test Sites. Presentation January 11, 2010.

Dzombak, D.A. and F.M.M. Morel, 1990. Surface Complexation Modeling. John Wiley \& Sons, New York, p. 91. 
Hinedi, Z.R., S. Goldberg, C. Chang, and J.P Yesinowski, 1992. A 31P and 1H MAS NMR study of phosphate sorption onto calcium carbonate. Journal of Colloid and Interface Science, 152(1):141-165.

Hu, Q.H., M. Zavarin, and T.P. Rose, 2008. Effect of reducing sensitive groundwater on the retardation of redox-sensitive radionuclides. Geochemical Transactions, 9(12):1-24.

Ingraham, N.L., B.F. Lyles, R.L. Jacobson, and J.W. Hess,1991. Stable isotopic study of precipitation and spring discharge in southern Nevada. Journal of Hydrology 125:243-258.

IT Corporation and Desert Research Institute, 1995. Evaluation of Soil Radioactivity Data from the Nevada Test Site. DOE/NV-380 UC-700. Las Vegas, NV.

Jin, S.M. and S.A. Sader, 2005. Comparison of time series tasseled cap wetness and the normalized difference moisture index in detecting forest disturbances. Remote Sensing of Environment, 94(3):364-372.

Kersting, A. and P. Reimus (eds.), 2003. Colloid-facilitated transport of low-solubility radionuclides: a field, experimental, and modeling investigation. Lawrence Livermore National Laboratory UCRL-ID-149688.

McArthur, R.D., 1991. Radionuclides in Surface Soil at the Nevada Test Site. Desert Research Institute, Water Resources Center, Publication \# 45077, Las Vegas, NV.

McArthur, R.D. and S. W. Mead, 1989. Nevada Test Site Radionuclide Inventory and Distribution Program: Report \#5. Areas 5, 11, 12, 15, 17, 18, 19, 25, 26, and 30. Desert Research Institute, Water Resources Center, Publication \# 45067, Las Vegas, NV.

Miller, J.J., R.H. French, S.A. Mizell, M.E. Cablk, and C.B. Kratt, 2011. Using doppler radar precipitation measurements to enhance estimates of playa inundation. American Society of Civil Engineers - Environmental and Water Resources Institute, World Environmental and Water Resources Congress 2011, May 22-26, Palm Springs, California.

Parkhurst. D.L. and C.A.J. Appelo, 1999. User’s Guide to PHREEQC (Version 2)—A Computer Program for Speciation, Batch-Reaction, One-Dimensional Transport, and Inverse Geochemical Calculations. U.S. Geological Survey Water Resources Investigations Report 99-4259.

Šimůnek, J., M. Šejna, and M.Th. van Genuchten, 1998. The HYDRUS-1D Software Package for Simulating the One-Dimensional Movement of Water, Heat, and Multiple Solutes in Variably Saturated Media. Version 2.0, IGWMC-TPS-70, International Ground Water Modeling Center, Colorado School of Mines, Golden, Colorado, p. 202.

Stipp, S. L. S., 1999. Toward a conceptual model of the calcite surface: hydration, hydrolysis, and surface potential. Geochimica et Cosmochimica Acta, 63(19):31213132. 
Thomas, J.M, F.C. Benedict, Jr., T.P. Rose, R.L. Hershey, J.B. Paces, Z.E. Peterman, I.M. Farnham, K.H. Johannesson, A.K. Singh, K.J. Stetzenbach, G.B. Hudson, J.M. Kenneally, G.F. Eaton, and D.K. Smith, August 2002. Geochemical and Isotopic Interpretations of Groundwater Flow in the Oasis Valley Flow System, Southern Nevada. Desert Research Institute Publication No. 45190.

Tyler, S.W., J.B. Chapman, S.H. Conrad, D.P. Hammermeister, D.O. Blout, J.J. Miller, M.J. Sully, and J.M. Ginanni. Soil-water flux in the southern Great Basin, United States: Temporal and spatial variations over the last 120,000 years. Water Resources Research 32(6):1481-1499.

Wazne, M., G.P. Korfiatis, and X. Meng, 2003. Carbonate effects on hexavalent uranium adsorption by iron oxyhydroxide. Environmental Science \& Technology, 37:36193624.

Zavarin, M., S.K. Roberts, T.P. Rose, and D.L. Phinney, 2002. Validating Mechanistic Sorption Model Parameters and Processes for Reactive Transport in Alluvium. Lawrence Livermore National Laboratory UCRL-ID-149728.

Zavarin, M. and C. Bruton, 2004a. A Non-Electrostatic Surface Complexation Approach to Modeling Radionuclide Migration at the Nevada Test Site: I. Iron oxides and calcite. Lawrence Livermore National Laboratory UCRL-TR-208673.

Zavarin, M. and C. Bruton, 2004b. A Non-Electrostatic Surface Complexation Approach to Modeling Radionuclide Migration at the Nevada Test Site: II. Aluminosilicates. Lawrence Livermore National Laboratory UCRL-TR-208672.

Zavarin, M., S.K. Roberts, A.M. Hakem, A.M. Sawvel, and A.B. Kersting, 2005. Eu(III), Sm(III), Np(V), Pu(V), and Pu(IV) sorption to calcite. Radiochimica Acta, 93:93-102. 
APPENDIX A: Extent of inundation on Frenchman Flat playa during the winters of 2009-2010 and 2010-2011.

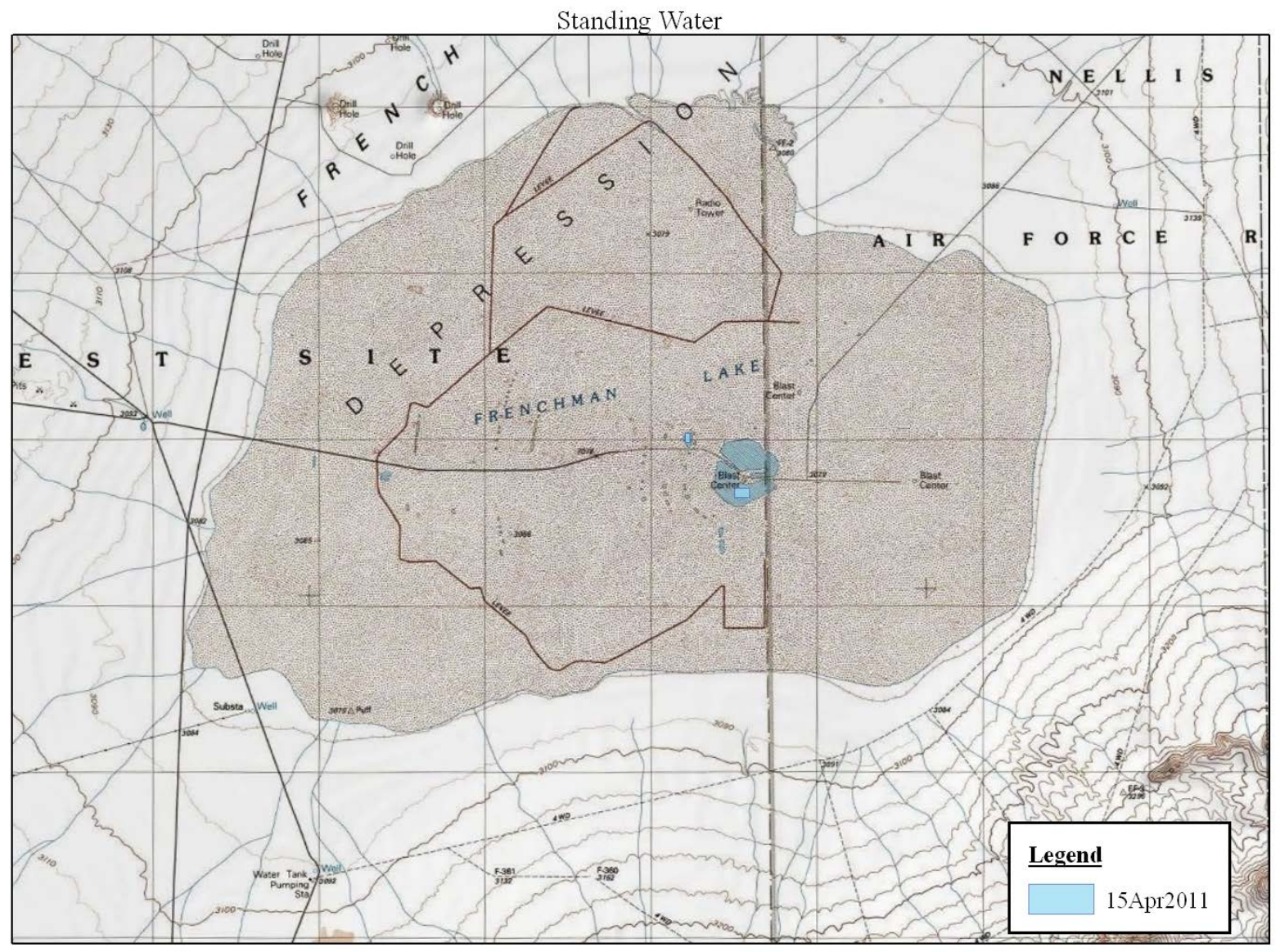

Firgure A-1. Extent of inundation on Frenchman Flat playa on April 15, 2011. 


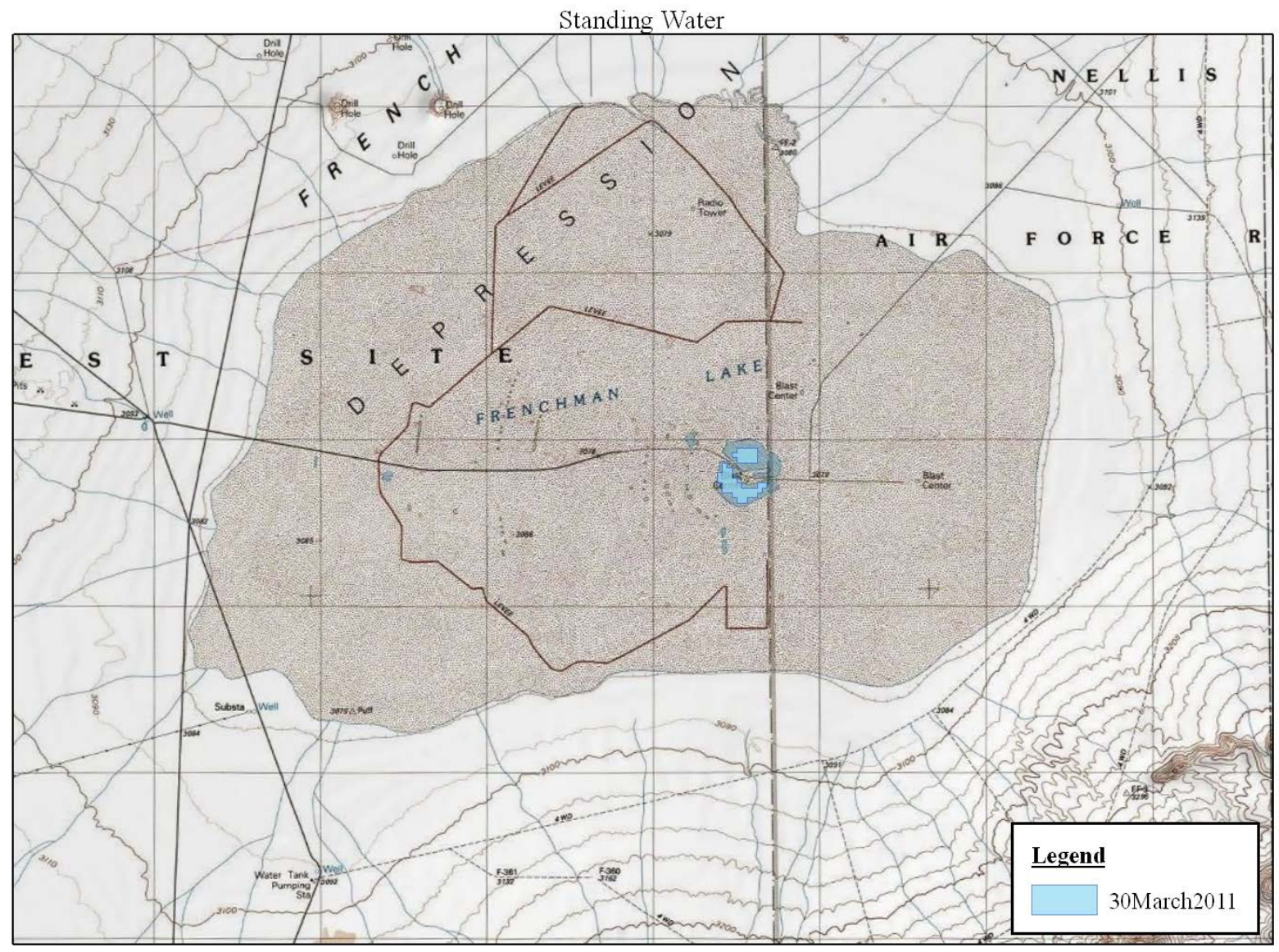

Firgure A-2. Extent of inundation on Frenchman Flat playa on March 30, 2011. 


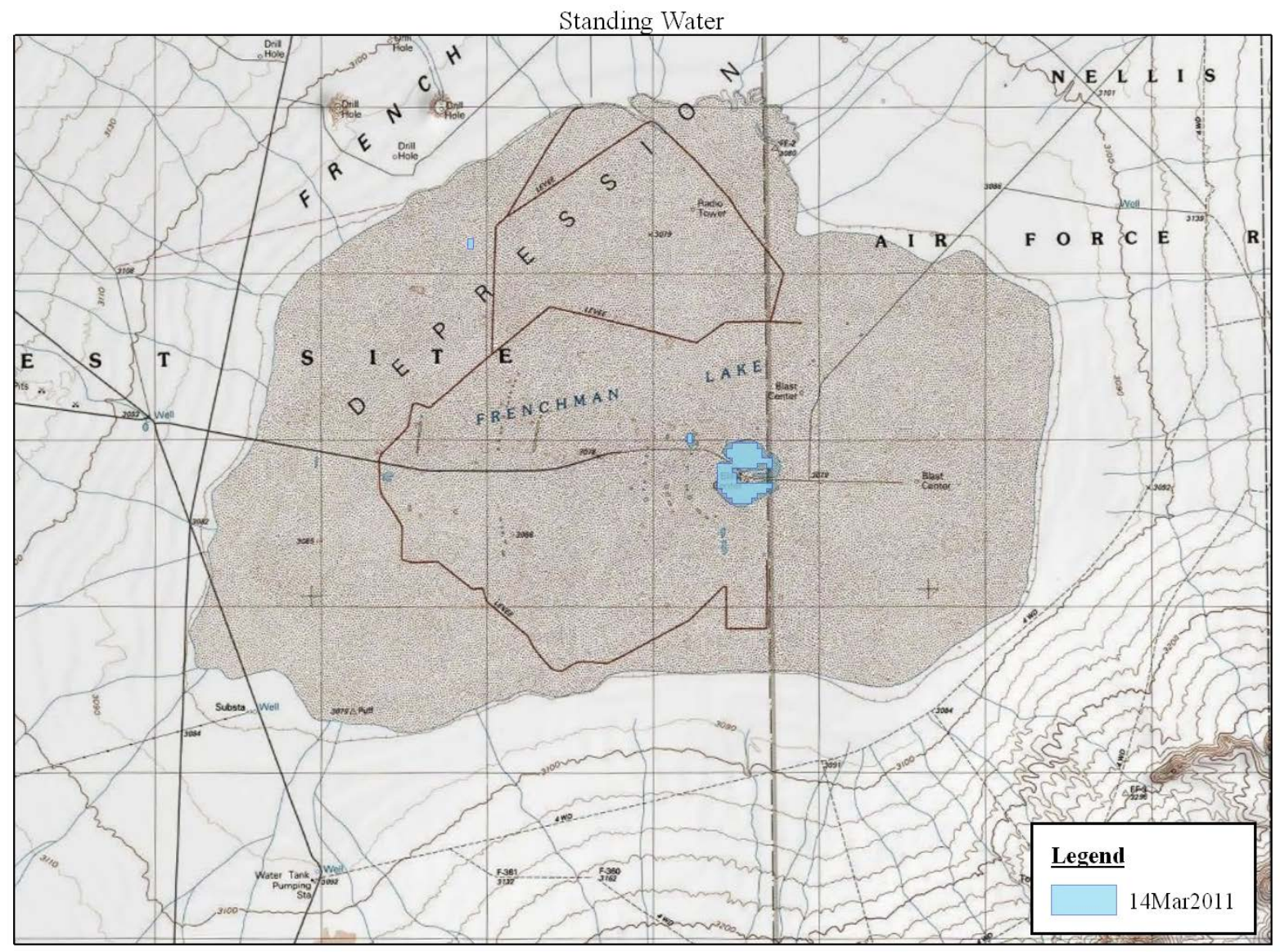

Firgure A-3. Extent of inundation on Frenchman Flat playa on March 14, 2011. 


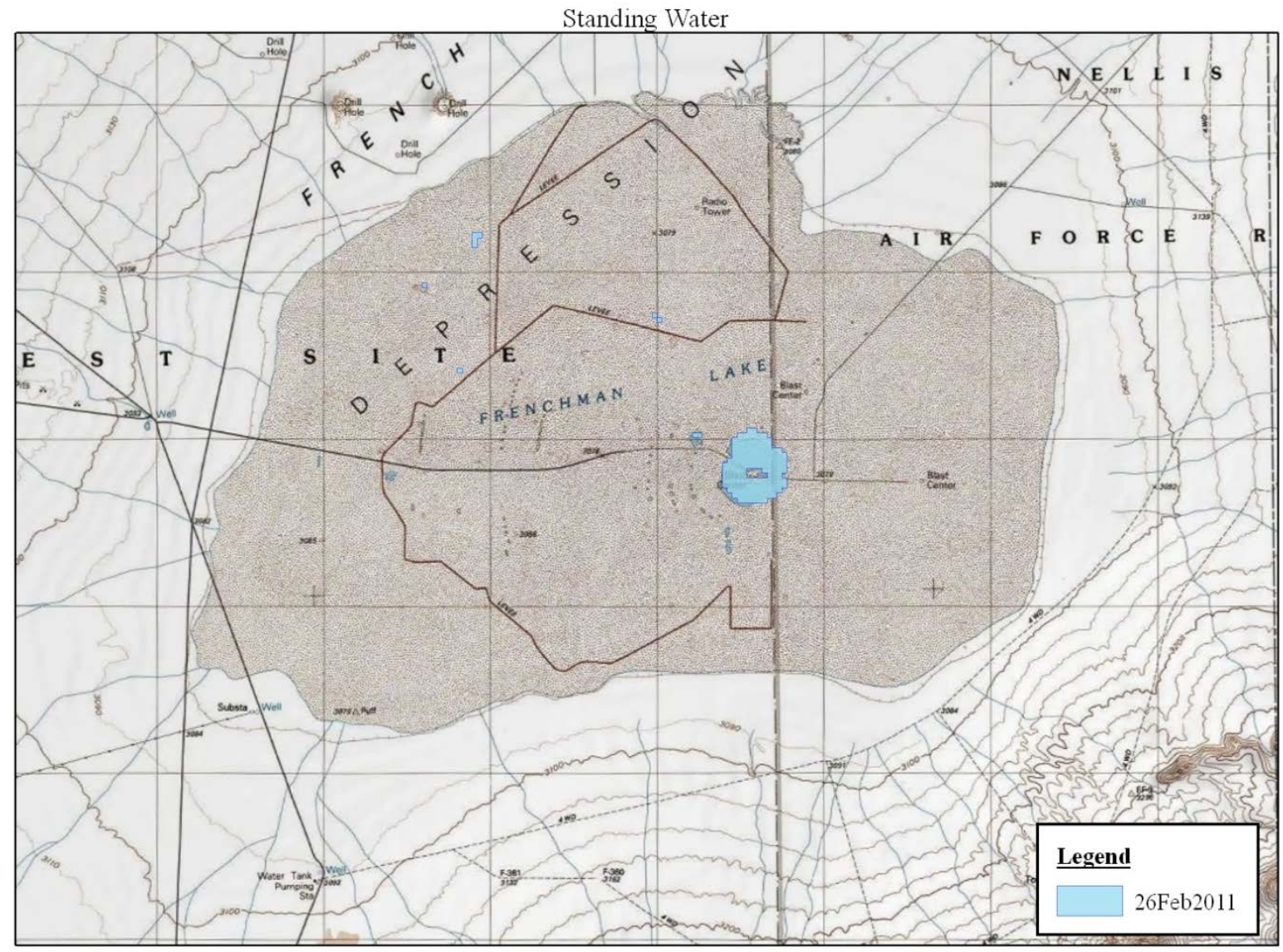

Firgure A-4. Extent of inundation on Frenchman Flat playa on February 26, 2011. 


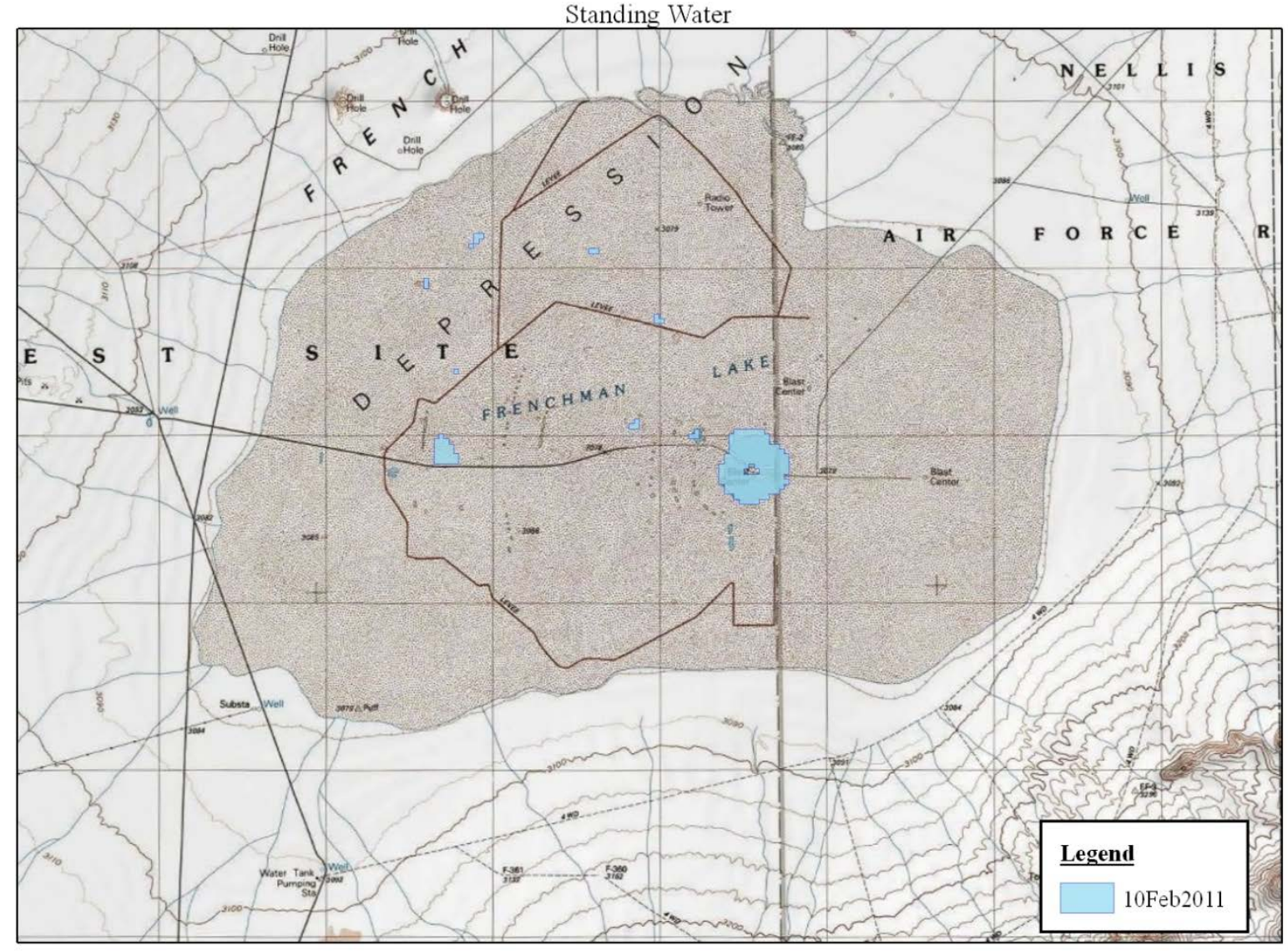

Firgure A-5. Extent of inundation on Frenchman Flat playa on February 10, 2011. 


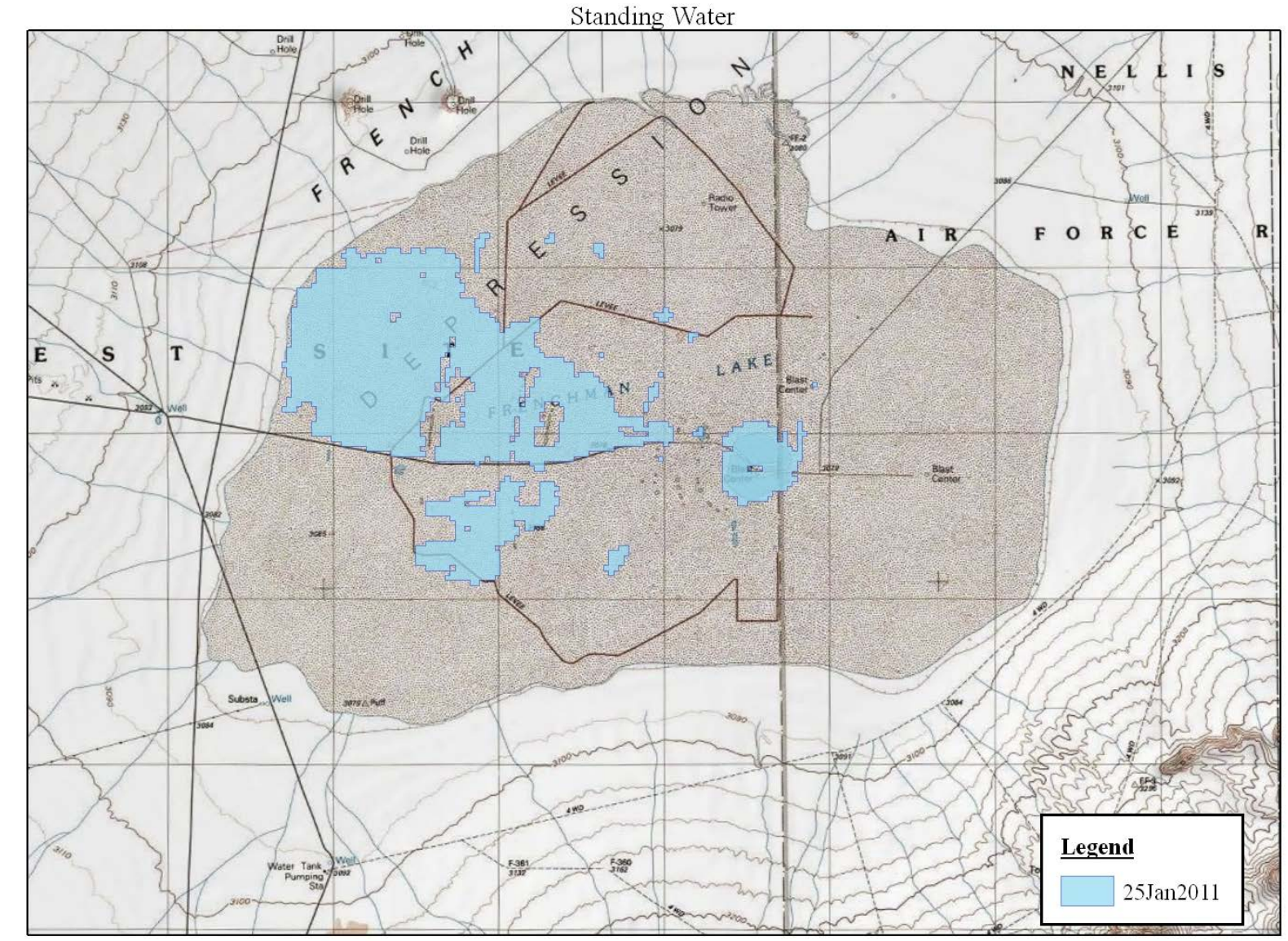

Firgure A-6. Extent of inundation on Frenchman Flat playa on January 25, 2011. 


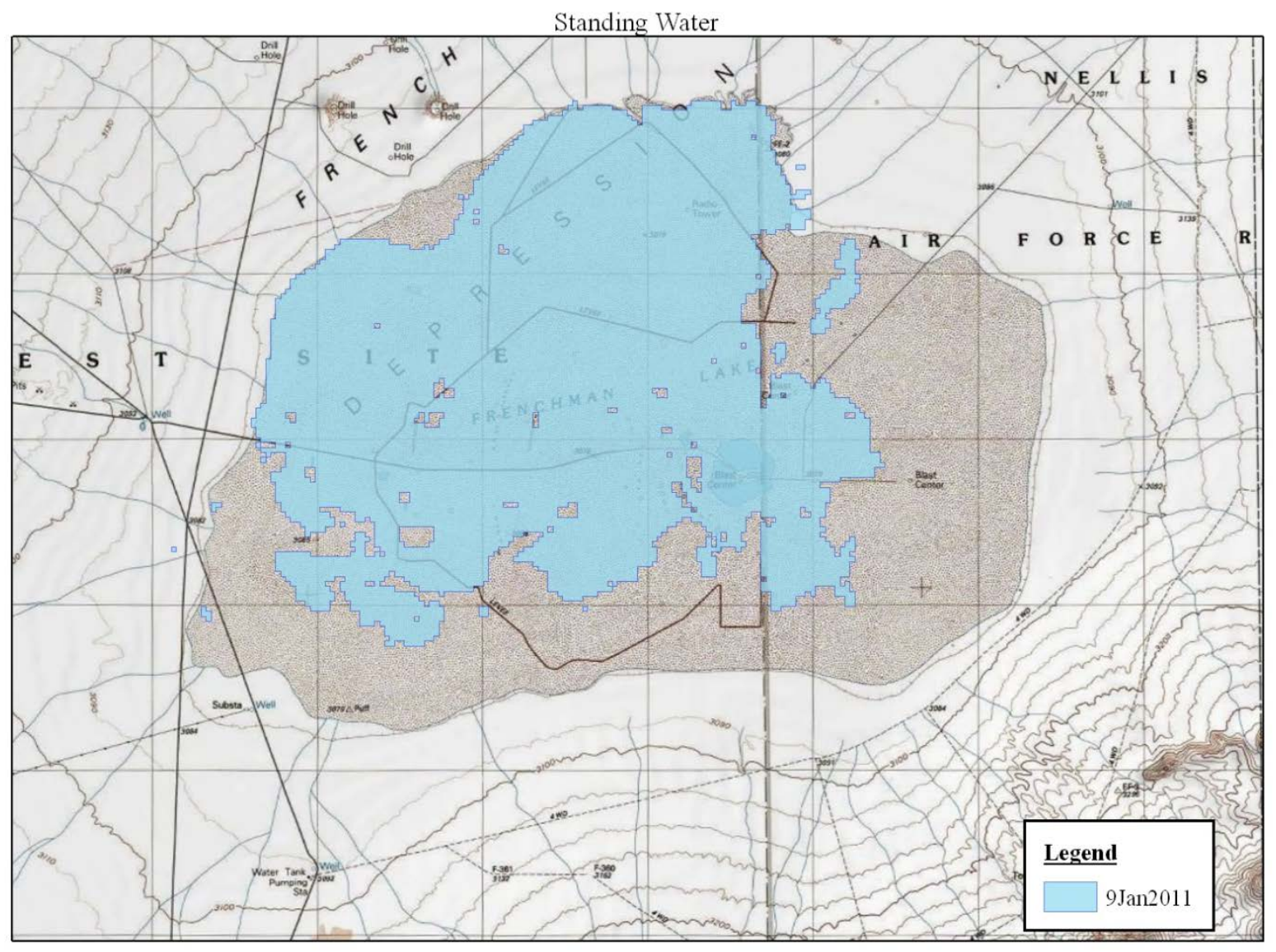

Firgure A-7. Extent of inundation on Frenchman Flat playa on January 9, 2011. 


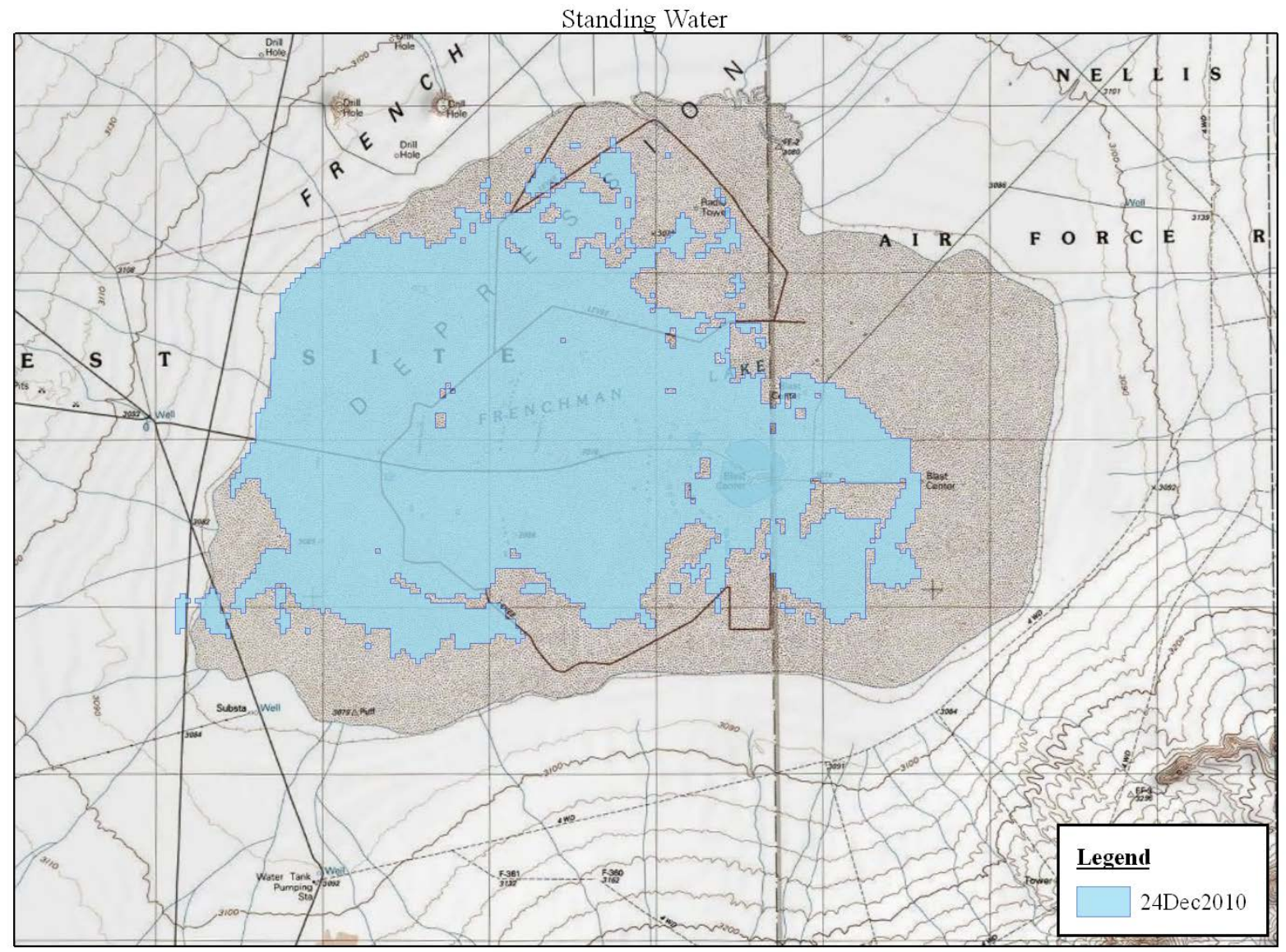

Firgure A-8. Extent of inundation on Frenchman Flat playa on December 24, 2010. 
Standing Water

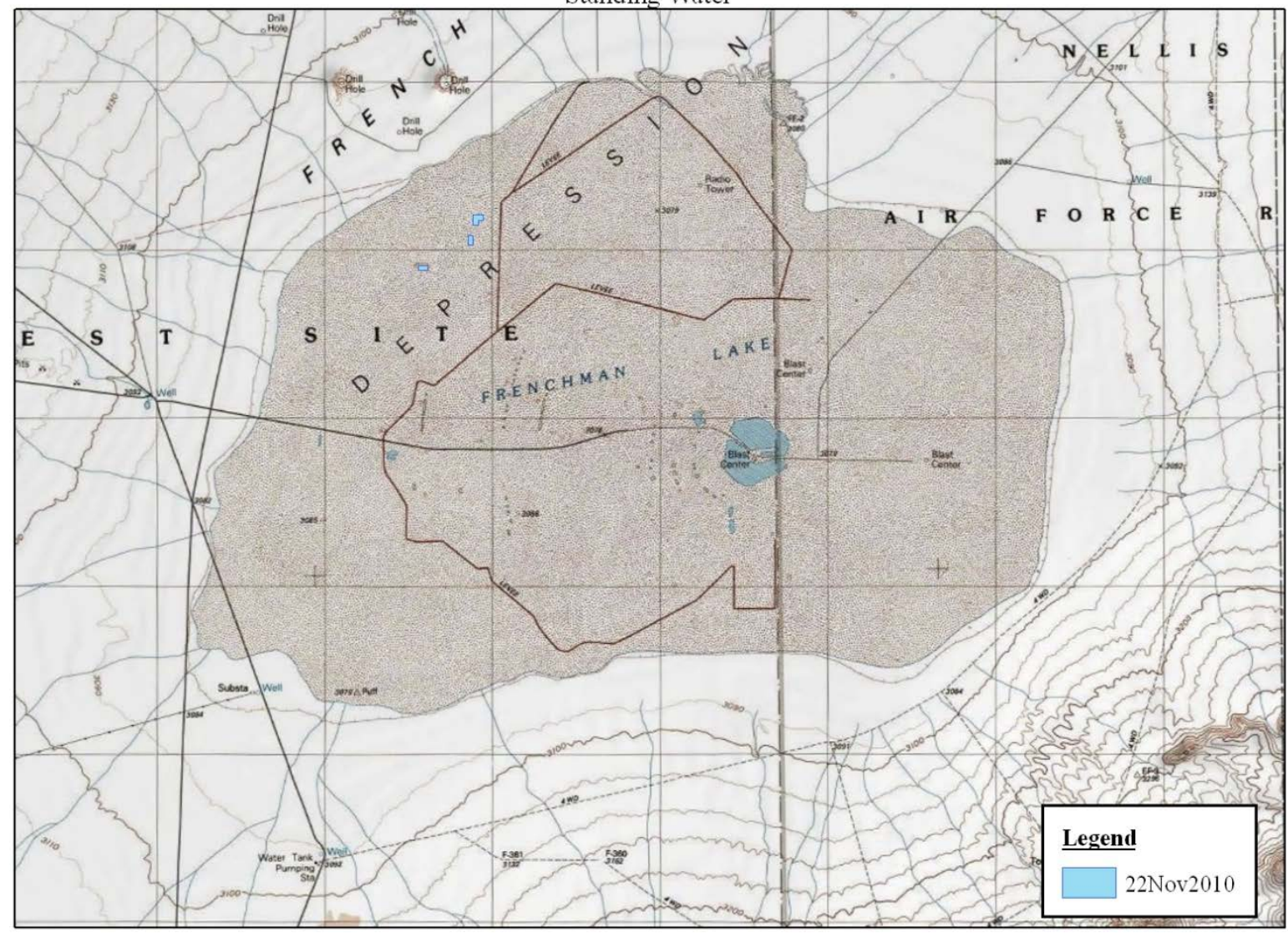

Firgure A-9. Extent of inundation on Frenchman Flat playa on November 22, 2010. 


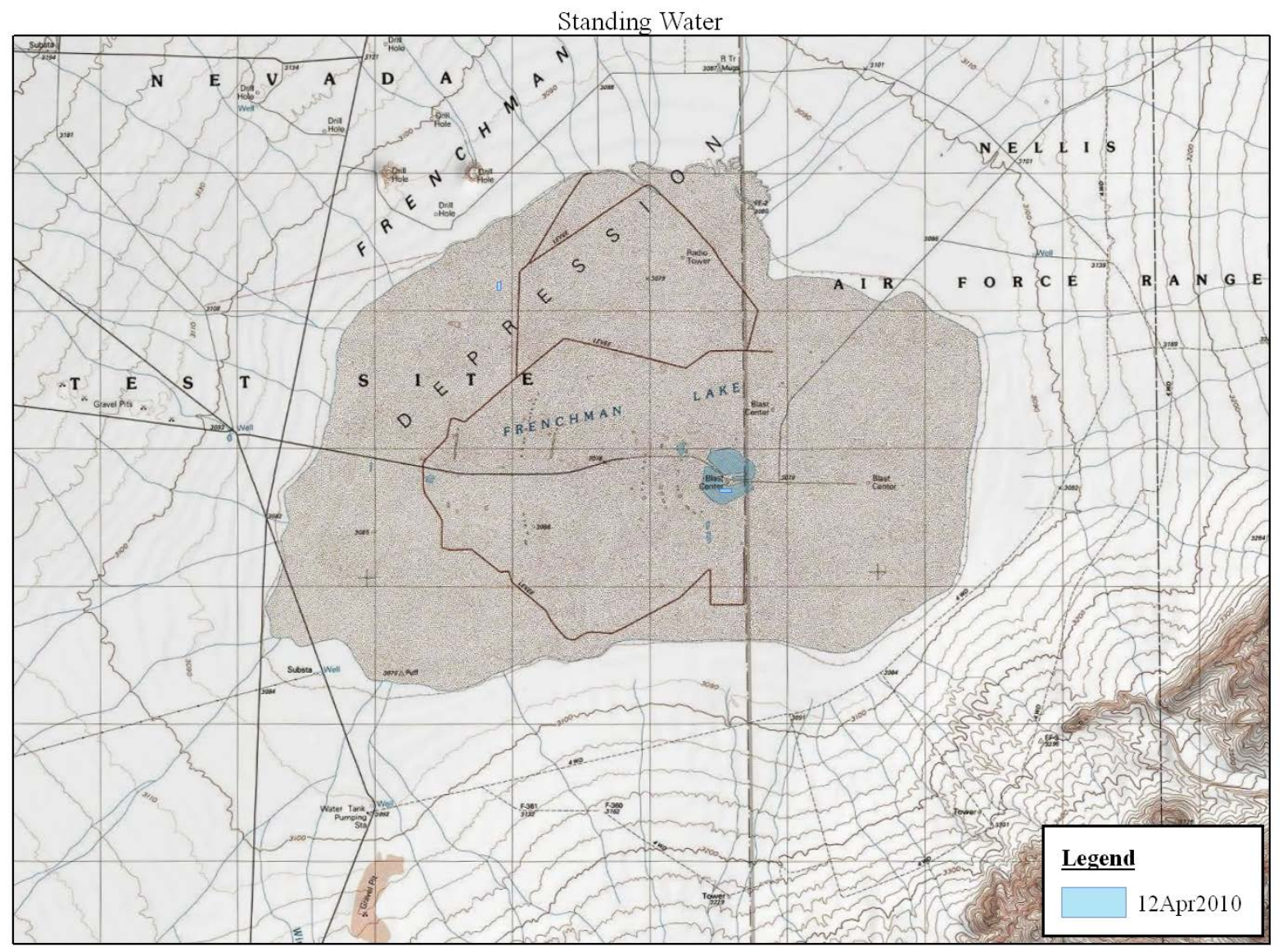

Firgure A-10. Extent of inundation on Frenchman Flat playa on April 12, 2010. 
Standing Water

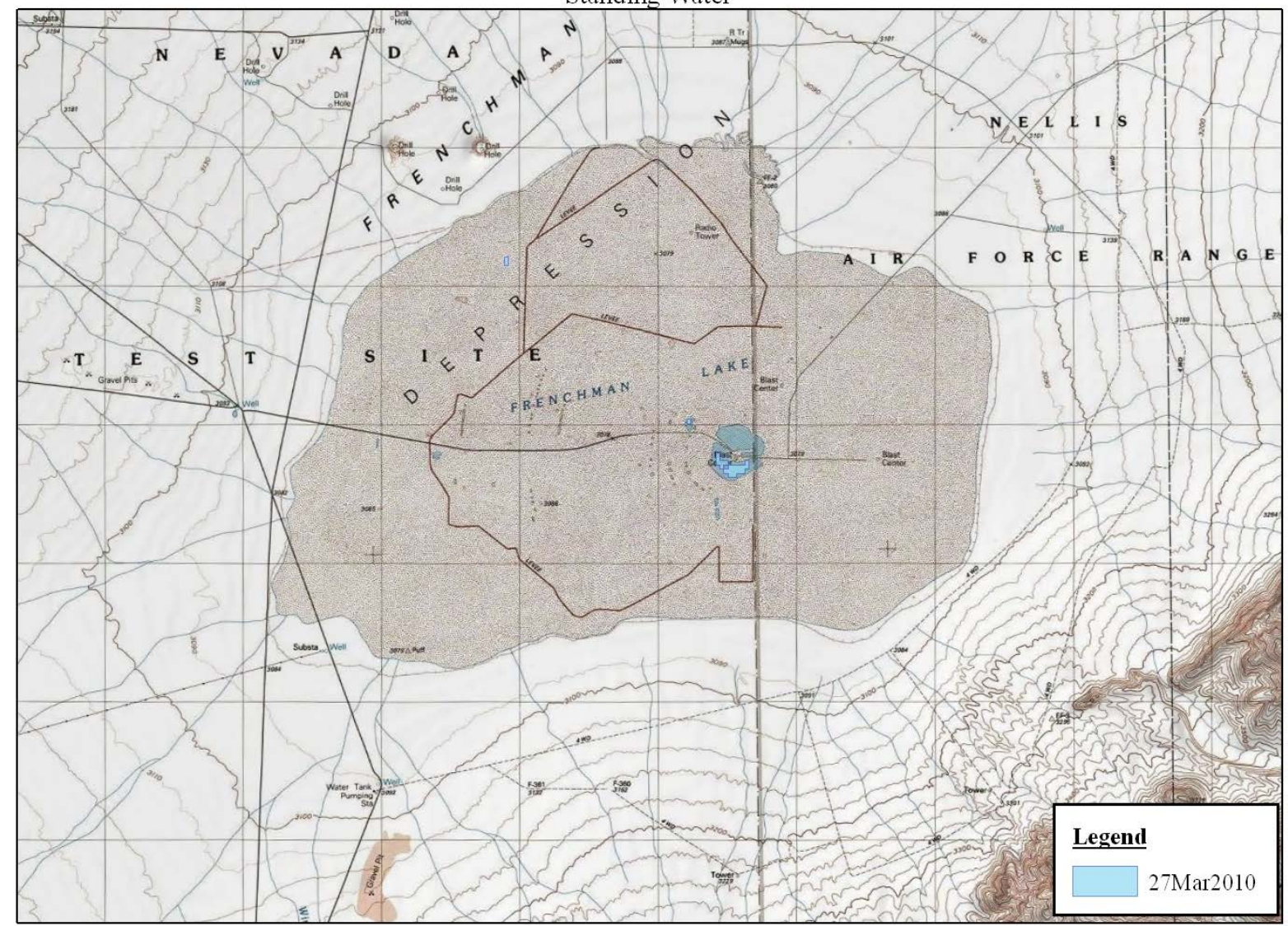

Firgure A-11. Extent of inundation on Frenchman Flat playa on March 27, 2010. 


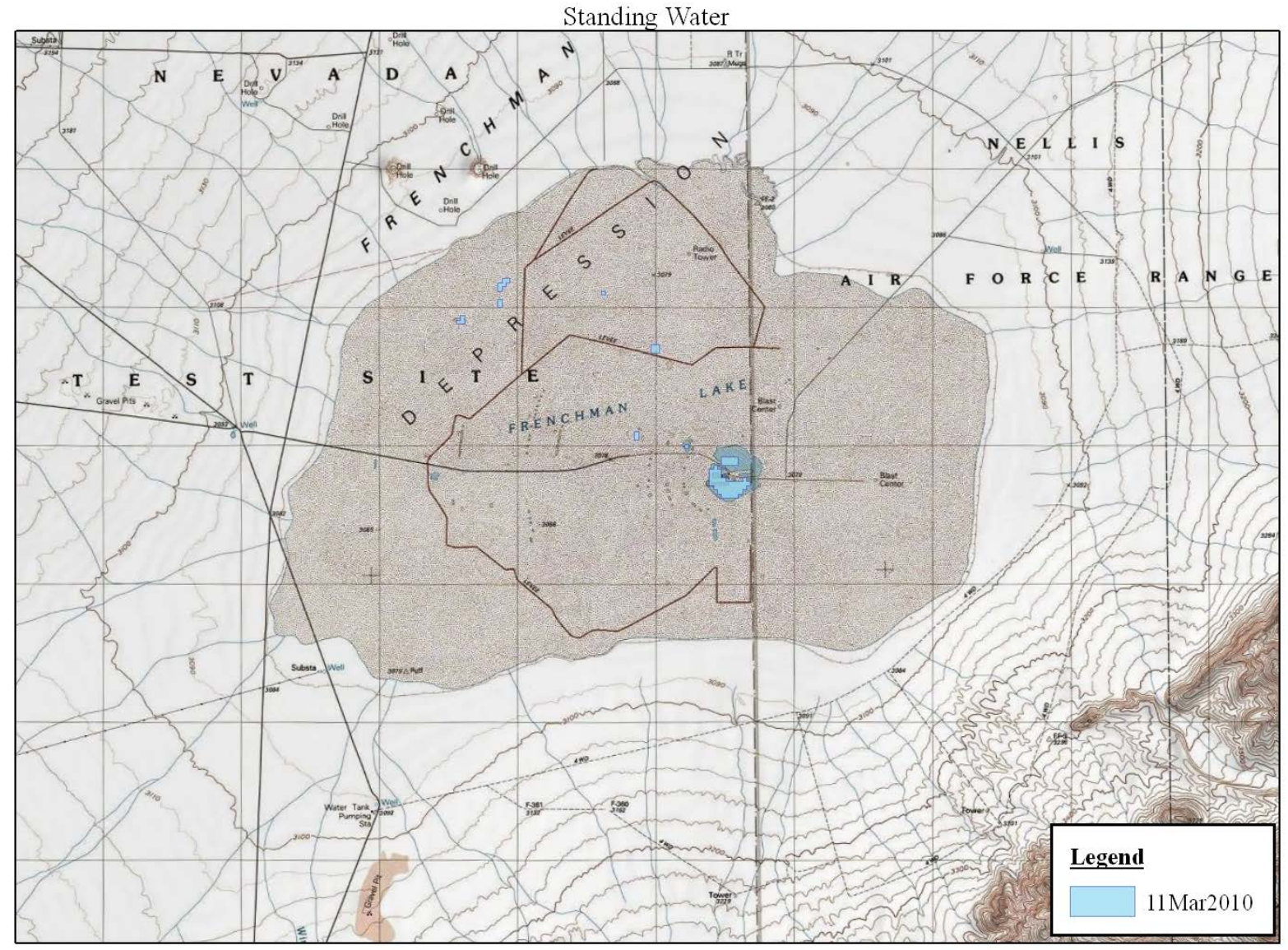

Firgure A-12. Extent of inundation on Frenchman Flat playa on March 11, 2010. 
Standing Water

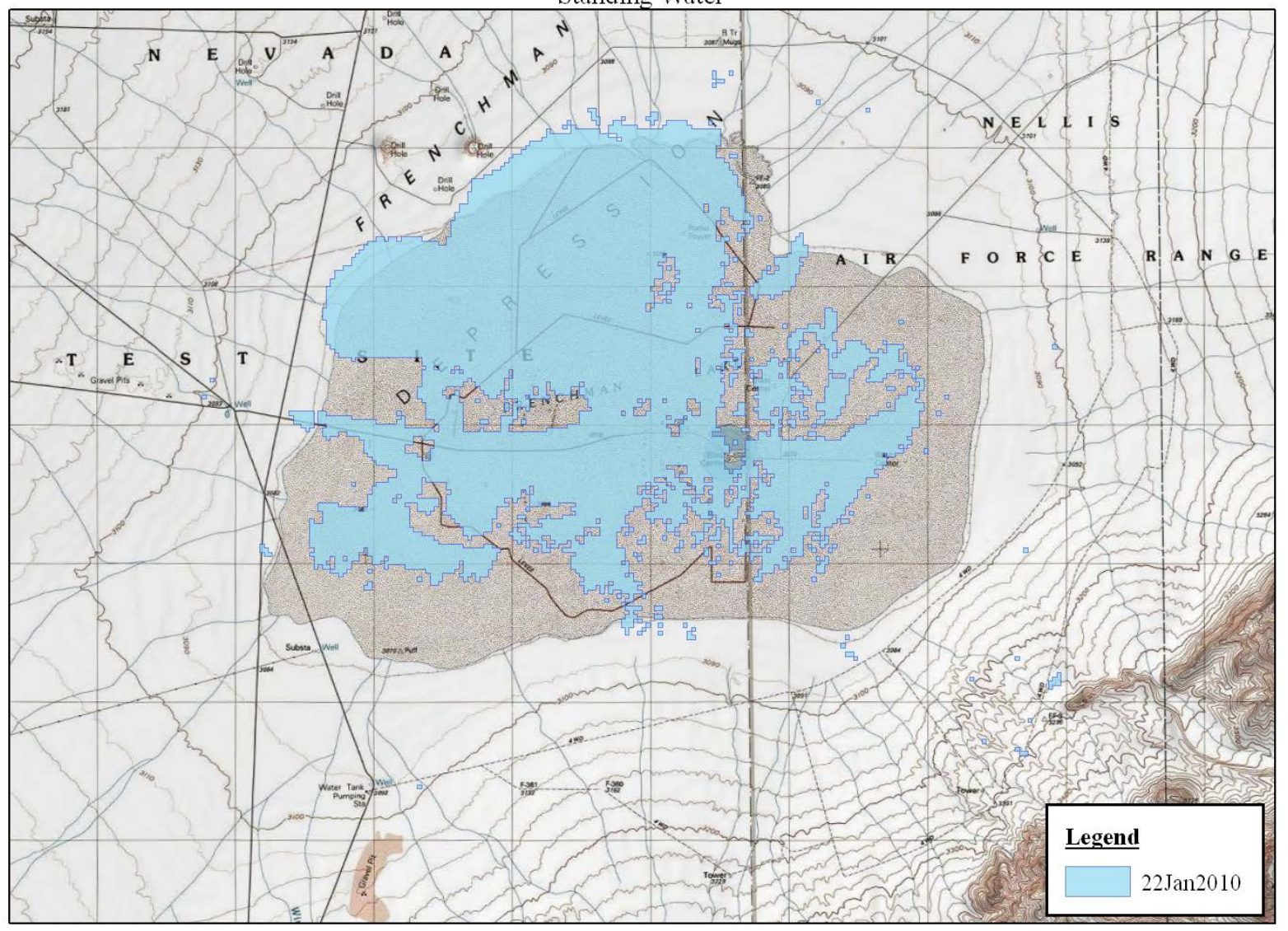

Firgure A-13. Extent of inundation on Frenchman Flat playa on January 22, 2010. 


\section{APPENDIX B: Saturation indices of important minerals, calculated by PHREEQC, for playa water samples.}

Table B-1. Saturation indices of important minerals, calculated by PHREEQC, for playa water samples.

\begin{tabular}{|c|c|c|c|c|c|c|c|c|c|c|c|c|c|c|c|}
\hline \multirow{3}{*}{$\begin{array}{l}\text { Sample Date } \\
\text { Sample \# }\end{array}$} & \multicolumn{15}{|c|}{ Saturation Index (SI) } \\
\hline & \multicolumn{3}{|c|}{$3 / 9 / 2010$} & \multicolumn{4}{|c|}{$1 / 5 / 2011$} & \multicolumn{4}{|c|}{$1 / 26 / 2011$} & \multicolumn{4}{|c|}{$2 / 16 / 2011$} \\
\hline & \#1 & \#2 & \#3 & $\# 1$ & \#2 & \#3 & $\# 4$ & \#1 & \#2 & \#3 & $\# 4$ & $\# 1$ & \#2 & \#3 & $\# 4$ \\
\hline \multicolumn{16}{|l|}{ Mineral or Gas } \\
\hline Albite & -4.46 & -5.13 & -6.80 & -5.41 & -5.02 & -5.60 & -6.32 & -5.17 & -4.94 & -5.64 & -4.71 & -4.95 & -4.04 & -5.87 & -6.94 \\
\hline Anorthite & -7.94 & -8.85 & -10.10 & -8.97 & -8.76 & -9.24 & -9.47 & -8.45 & -8.68 & -9.23 & -8.62 & -8.17 & -7.77 & -9.23 & -10.10 \\
\hline Ca-Montmorillonite & -3.93 & -5.29 & -7.47 & -4.97 & -7.33 & -7.81 & -6.62 & -3.85 & -4.95 & -7.13 & -5.48 & -3.98 & -3.67 & -6.15 & -7.41 \\
\hline Calcite & 0.30 & 0.02 & -0.01 & -0.87 & 0.20 & -0.20 & -0.58 & -0.50 & -0.02 & 0.27 & 0.34 & -0.05 & 0.37 & 0.29 & -0.11 \\
\hline $\mathrm{CO}_{2}(\mathrm{~g})$ & -3.07 & -3.24 & -3.22 & -3.78 & -5.46 & -5.60 & -4.19 & -2.96 & -3.25 & -4.21 & -3.55 & -3.05 & -3.07 & -3.03 & -3.17 \\
\hline Dolomite & 0.01 & -0.34 & -0.55 & -2.42 & -0.28 & -1.23 & -2.05 & -1.74 & -0.57 & 0.02 & 0.17 & -0.89 & 0.20 & 0.20 & -0.56 \\
\hline Gypsum & -3.15 & -3.64 & -3.77 & -4.06 & -4.03 & -4.48 & -3.62 & -3.26 & -3.42 & -3.36 & -3.37 & -3.07 & -2.94 & -3.17 & -2.94 \\
\hline Halite & -9.33 & -8.97 & -8.96 & -9.78 & -9.70 & -9.95 & -9.79 & -9.37 & -8.85 & -8.96 & -8.60 & -9.33 & -8.70 & -8.48 & -8.54 \\
\hline Illite & -3.88 & -5.06 & -7.17 & -5.09 & -6.34 & -6.99 & -6.57 & -4.19 & -4.78 & -6.43 & -5.02 & -4.15 & -3.57 & -5.83 & -7.12 \\
\hline K-feldspar & -2.15 & -3.01 & -4.84 & -3.11 & -2.75 & -3.36 & -4.10 & -2.78 & -2.76 & -3.48 & -2.61 & -2.54 & -1.84 & -3.71 & -4.86 \\
\hline Kaolinite & -1.45 & -2.26 & -3.43 & -2.03 & -4.57 & -4.79 & -3.23 & -1.07 & -2.06 & -3.87 & -2.65 & -1.33 & -1.35 & -2.70 & -3.34 \\
\hline Quartz & 0.24 & -0.05 & -0.65 & 0.03 & 0.13 & 0.00 & -0.25 & 0.08 & 0.02 & -0.18 & 0.06 & 0.14 & 0.34 & -0.33 & -0.68 \\
\hline $\mathrm{SiO}_{2}(\mathrm{a})$ & -1.12 & -1.41 & -2.01 & -1.33 & -1.23 & -1.36 & -1.61 & -1.29 & -1.34 & -1.54 & -1.30 & -1.22 & -1.02 & -1.69 & -2.04 \\
\hline
\end{tabular}

Saturation indices were calculated at $10^{\circ} \mathrm{C}$ 